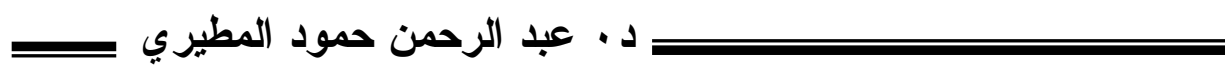

\title{
مفهوم الصفة
}

\section{وأثره في الاستتباط الفقهي في النوازل الفقهية}

د. عبد الرحمن حمود المطيري(")

المقدمة:

الحمد اله الهادي إلى سبيل الرشاد، الموفق بكرمه لطرق السداد، و الصلاة و السلام على محمد عبده ورسوله وحبيبه وخليله، المصطفى بتعميم دعوته ورسالته، المفضل على الأولين و الآخرين من بريته، و على آله وصحبه ومن اهتدى بهديه، و اتبع سنته إلى يوم الدين. أما بعد:

فما من حادثة إلا وفيها حكم لله تعالى من تحليل أو تحريم أو إيجــاب أو

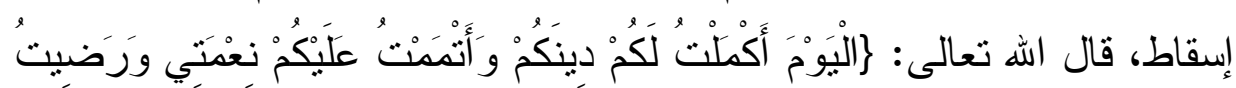

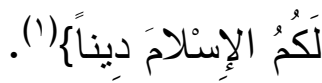

ومعلوم أن كل حادثة لا يوجد فيها نص، فالنصوص معدودة متناهية، و لا نهاية لما يقع من الحو ادث إلى قيام الساعة، فإذا كانت النصوص قاصرة عن تناول جميع الحوادث، وكان التكليف و اقعًا بمعرفة الأحكام، لم يكن لنا طريق نتوصل به إلى معرفتها إلا استعمال مفاهيم الكتاب و السنة، و القياس، و الأصل

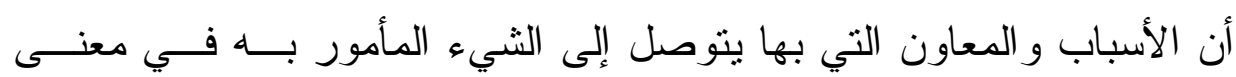
المأمور به و المنطوق بذكره، فيكون الأمر الو ارد بالجملة منطويًا عليها، و إنما يقع السكوت عنها اختصارًا للكلام و اعتمادًا على فهم المخاطب.

الأستاذ المساعد في قسم الفقه المقارن و السياسة الثرعية - كلية الثريعة - 
و أم المفاهيم هو مفهوم الصففة، كما قال إمام الحرمين الجويني: الو عبّر

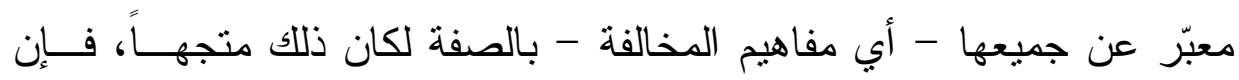
المعدود و المحدود موصوفان بعدهما وحدهما، و المخصوص بمان بالكون في مكان

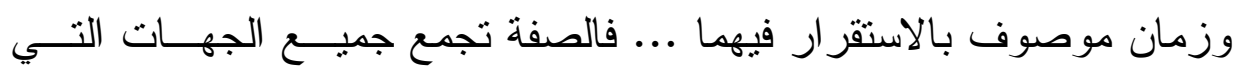
ذكر ها، ومن ينكر المفهوم فإنه يأبى القول في جميع هذه الوجوهـ" (').

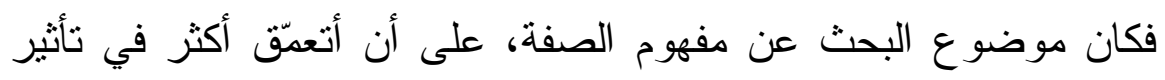

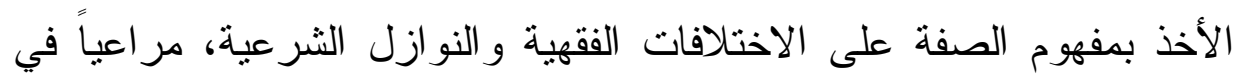
ذللك أصول البحث العلمي، فكان العنوان: مفهوم الصفة وأثره في الاستتباط الفقهي في النوازل الفقهية. مشكلة البحث و أسئلته:

يقوم البحث على محاولة الإجابة عن تساؤ لات تتعلّق بمفهوم الصفة:

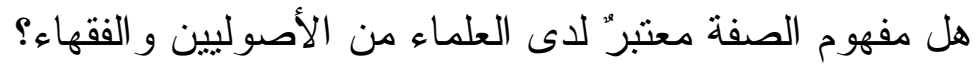

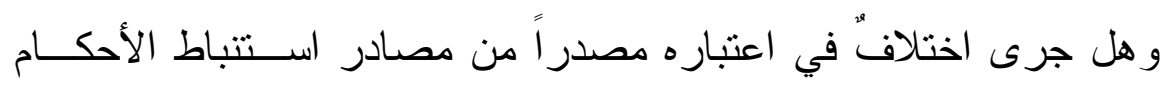
الثر عية؟ و هل العلماء الذين قبلوه وضعو الله ضو ابط وشروطاً؟ وما تلك الضو ابط؟ لهاك

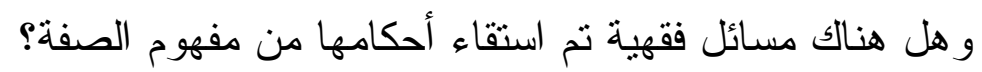
و هل يمكن الاستفادة من مفهوم الصفة في الاجتهادات المتعلقة بــالنو ازل الفقهية المعاصرة؛ فهذه أسئلة ونقاط سيحاول الباحث الإجابة عنها في هذه الدراسة بعون الله تعالى.

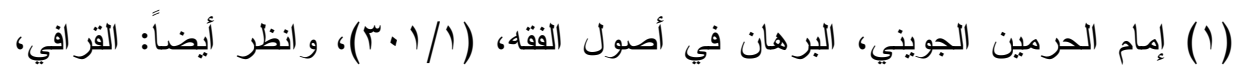

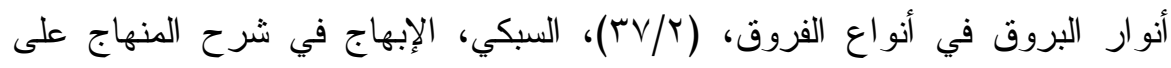

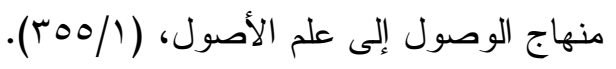
$-v \varepsilon-$ 
د · · عبد الرحمن حمود المطيري عـ

أهداف البحث:

يعمد البحث للحصول على إجابة و افية حول أثز مفهـوم الــصفة فـي

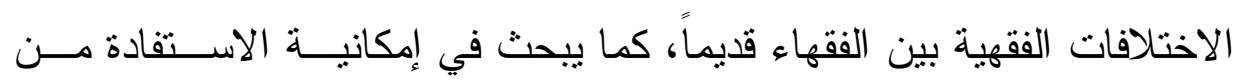
مفهوم الصفة في بعض النوازل الفقهية المعاصرة، مما يسهل على أهل النظر و الاستتباط الاستفادة الجيدة من هذا البحث الأصولي المتعلق بدلالات الألفاظ، و أثره الفقهي، فيكون في هذا خير" عميم على المسلمين. أهمية البحث:

تكمن أهمية البحث في علاقته بدلالات النصوص الثرعية، التـي هـي

المصدر الأول للبحث عن الأحكام الفقهية، وهذا أمر مهُء للمجـــامع الفقهيــة و الهيئات الإفتائية التي تستتبط للمسلمين الأحكام الثرعية في النوازل الفقهية. الار اسات السابقة:

وجد الباحث در استين نكلمتا عن مفهوم الصفة:

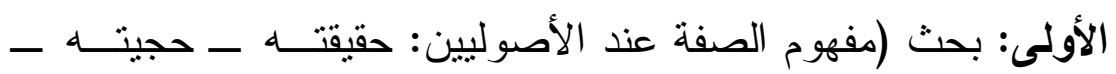

أثره) للاكتور أحمد بن محمد السر اح، و البحث مخصص في أغلبه في عرض

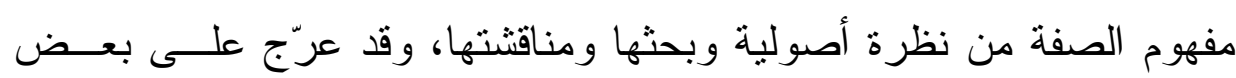
المسائل الفقهية عَرَضَاً باقتضاب.

الثانية: بحث (مفهوم الصفة وأثز الاختلاف فيه بين الأصوليين علـى بلى

الفروع) للاكتور علي أبو البصل، و البحث أيضاً مخصص غالبه فــي نقــاش مفهوم الصفة في أبو اب أصول الفقه، وقد عرّج على بعض المسائل الفقهـــة باختصار ، وهي المسائل نفسها المبثوثة في كتب الأصول. 


\section{= الجديد في البحث:}

يرى الباحث أن هناك نقصاً في البحوث التي تنتاول مفهوم الصفة، كمـــا

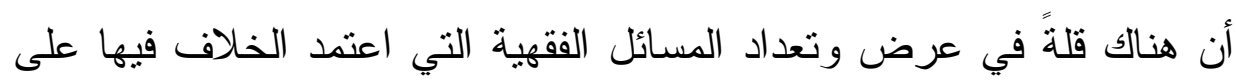

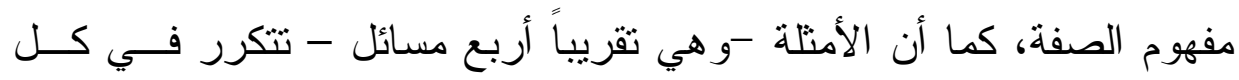
الكتب و الأبحاث، مما يجعل الباحث يستغرب من تو ارد نفس الأمثلة في أغلب

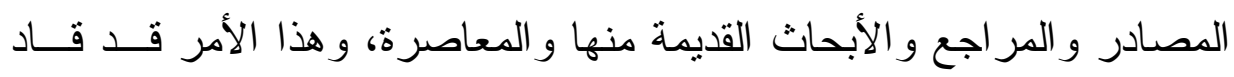
الباحث لعرض مسائل أخرى أغفلتها أغلب الكتب.

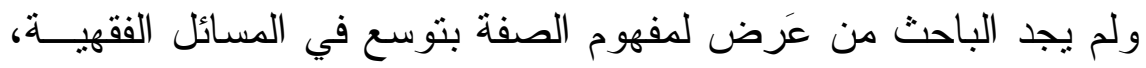

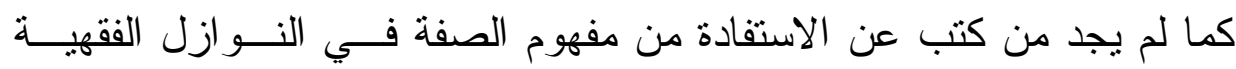

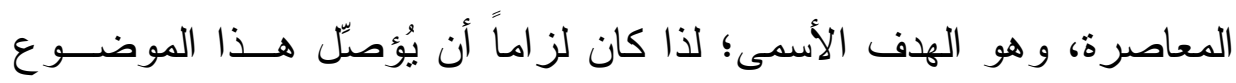

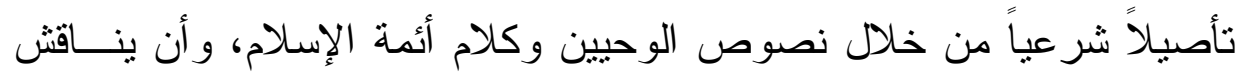

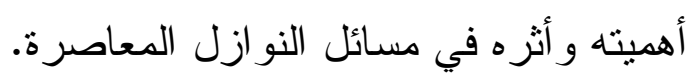

$$
\text { منهج البحث و إجر اءاته: }
$$

المنهج الذي سأنبعه في هذه الدراسة مزيج بين المنهج الوصفي، و المنهج

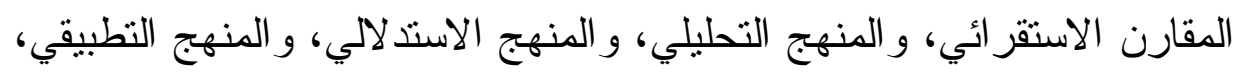
كما يلي: - (لمثارن

المنهج الوصفي: من خلال تحديد المسائل العلمية ووصفها، بدقة

$$
\text { وموضو عية. }
$$

المنهج المقارن الاستقر ائي: من خلال استقر اء أقو ال الأصوليين و الفقهاء وتتبعها و المقارنة بينها ومناقثتها بما يتتاسب مع البحت البحث و الدر اسة.

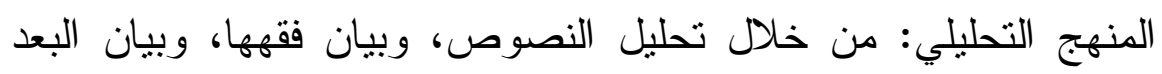
المقاصدي في المسألة. 
د. • عبد الرحمن حمود المطيري حس

المنهج الاستدلالي: بذكر الأدلة الثرعية في المسألة، وبيان وجه

الاستدلال بها، وترجيح ما ير اه الباحث أقرب إلى الصواب برد الفروع إلى الى الى

الأصول، و الظنيات إلى القطعيات.

المنهج التطبيقي: من خلال تطبيق النتائج المستتبطة من البحث على

$$
\text { حدود البحث: النول الفقية على أرض الو اقع. }
$$

اقتصرت في معالجة البحث على الفقه و أصوله.

$$
\text { هيكلية الدر استة وعناوين مواضيعها: }
$$

وضع الباحث هيكل البحث لغرض عرض البحث في أبهى صورة؛ راجياً

أن يناله التوفيق من الله سبحانه في ذلك.

وجاء هيكل البحث فى مقدمة، وثلاثثة مباحث، وخاتمة، على النحو التالي:

$$
\text { مقدمة البحث. }
$$

* المبحث الأول: تعريف 》مفهوم الصفة《 وحجيته، وفيه مطلبان:

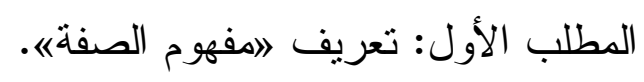$$
\text { المطلب الثاني: حجية 》هفهوم الصفة《. }
$$

* المبحث الثاني: شروط 》مفهوم الصفة/ وصوره، وفيه مطلبان:

$$
\text { المطلب الأول: شروط 》مفهوم الصفة《). }
$$

* المبحث الثالث: الآثار الفقهية المبنية على حجية 》مفهوم الصفةه)، وفيـه

$$
\text { مطلبان: }
$$

المطلب الأول: مسائل فقهية قديمة.

المطلب الثاني: مسائل فقهية معاصرة.

الخاتمة: وفيها أهم النتائج التي توصل إليها الباحث، و التوصيات. 
هذا، وقد بذل الباحث وسعه لإظهار هذا البحث في هذا العلم الذي هو من

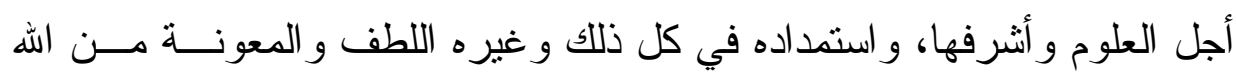
الكريم الرؤوف الرحيم، و عليه اعتماده.

و اله يسأل أن يغفر الزلات، ويعفو عن الهفوات، ويتجاوز اعناده عن الخطيئات،

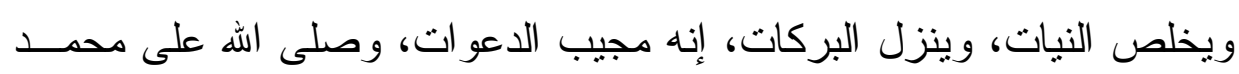

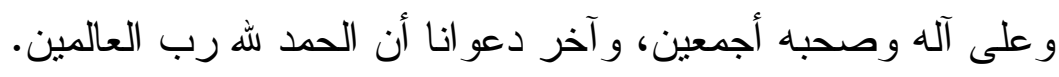




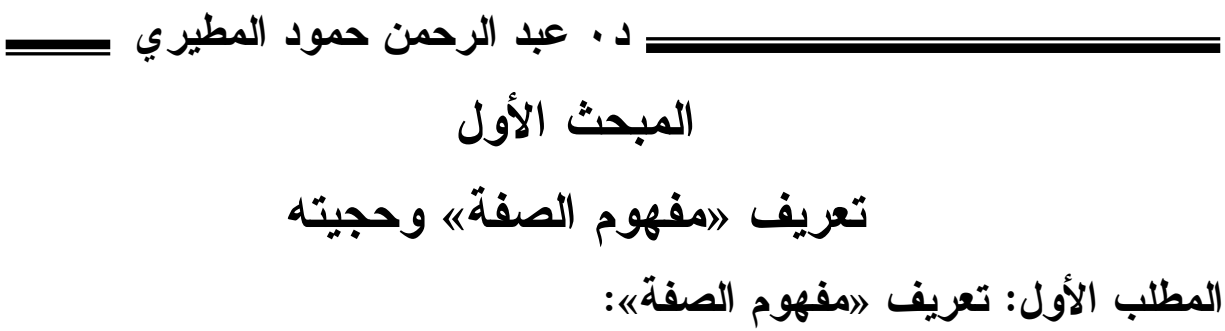

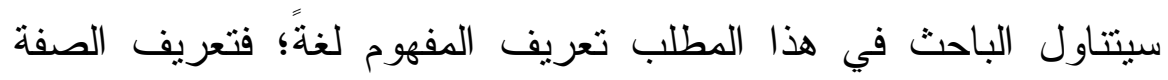

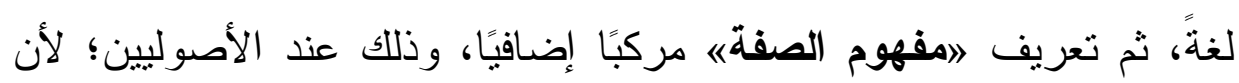
الحكم على الثيء فرع عن تصوره، مع التزام عدم التفصيل في شرح

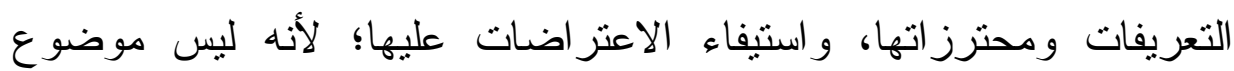

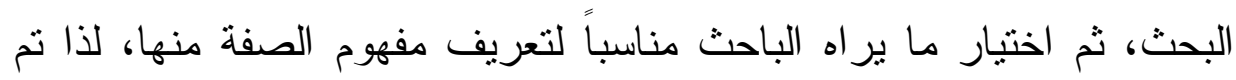
تقسيم هذا المطلب إلى ثلاثة فروع: الفرع الأول: تعريف 》المفهومه في اللغة:

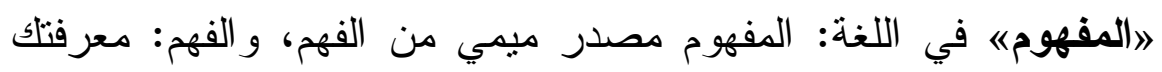

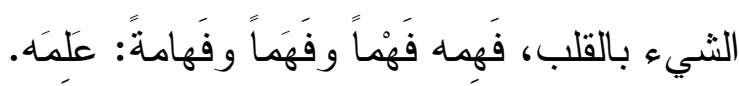

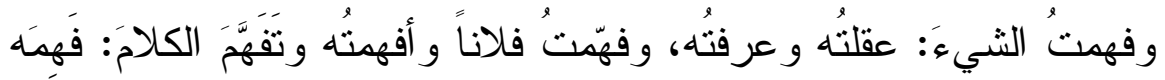
شيئًاً بعد شيء. وفهن.

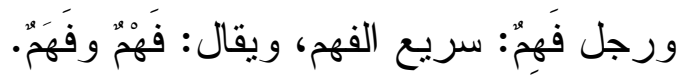
و أفهمه الأمر وفهمّهة إياه: جعله يفهمه.

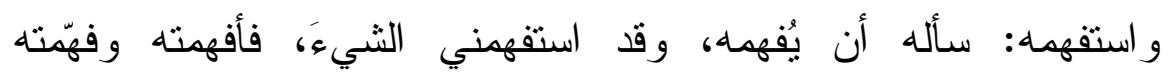
تفهيماً (1)

الفرع الثاني: تعريف 》الصفةه في اللفة: ״الصفةه في اللغة: مصدر وصف الثيء له و وعليه وصفاً وصفةً: حلاه، و الهاء عوض من الواو.

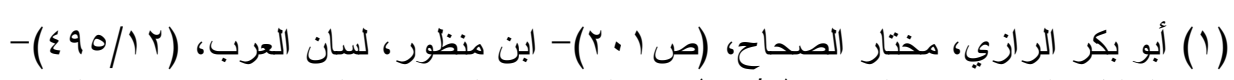

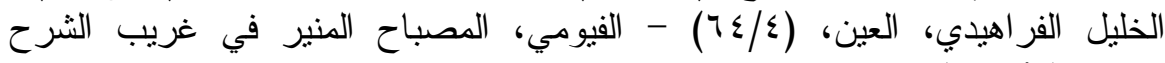
الكبير، ( ) ( 
وقيل: الوصف: الدصدر و الصفة: الحلية، و الوصف: وَصَفْكَ الثيء

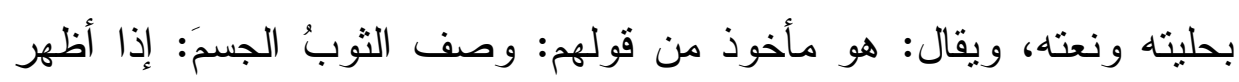
حاله وبيَّن هيئته.

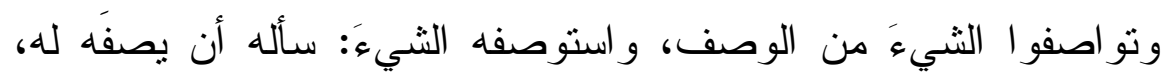

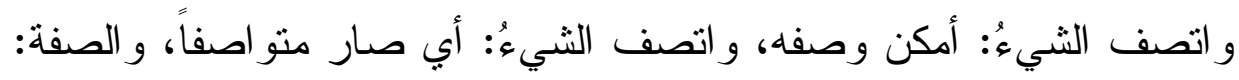
كالعلْم و السو اد.

وأما النحويون فلا يريدون بالصفة هذا؛ لأن الصفة عندهم: هي النعت، وله

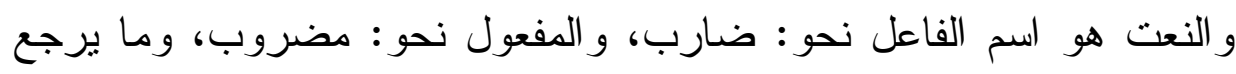

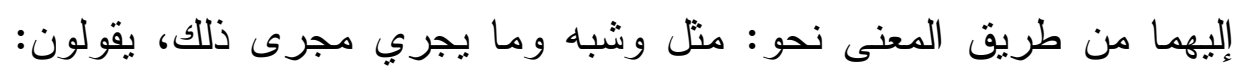

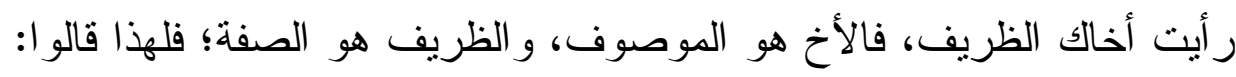

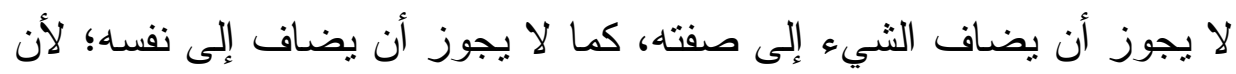

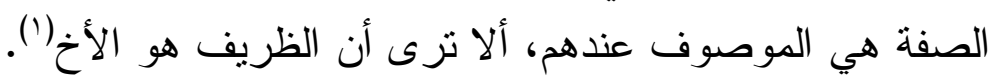

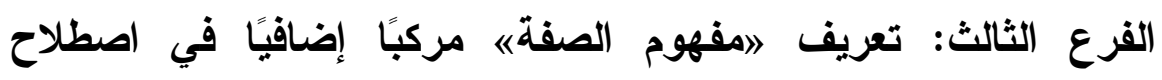

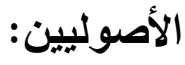

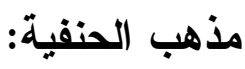

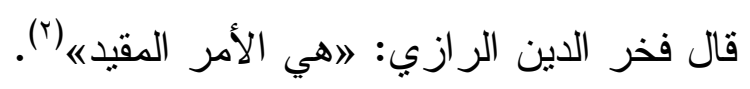

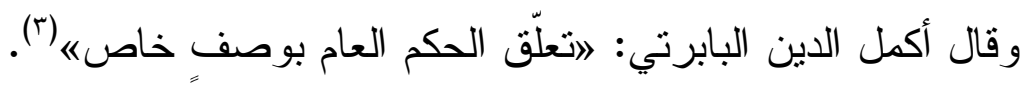

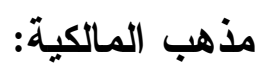

قال أبو بكر ابن العربي: 》هو تعليق الحكم على أحد وصفي الثيء، فيدل

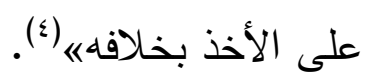

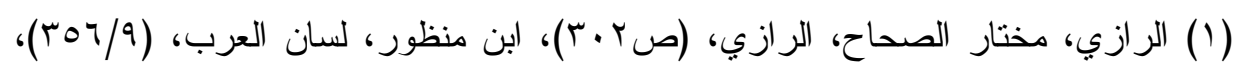

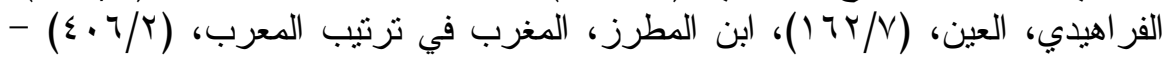

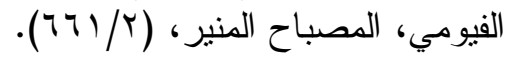

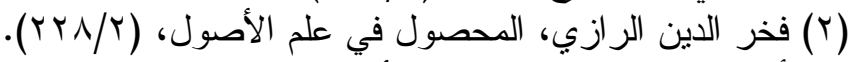

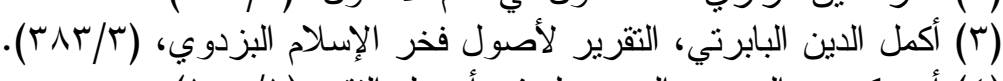

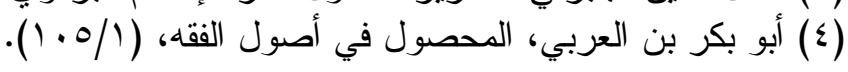




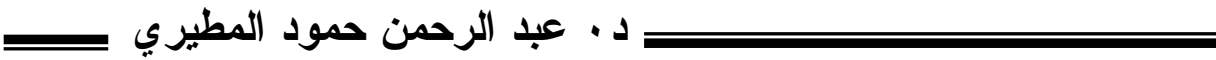

وقال الباجي: اأن يعلق الحكم على معنى في بعض الجنس، فيقضي ذلك

عند القائلين به نفي ذلك عما لم يكن به ذلك من ذلك الجنسه" (').

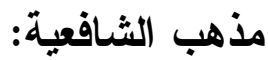

قال أبو إسحاق الثيرازي: الهو أن بعلق الحكم على أحد وصفَي

الثيءع) (r) (

وقال الغز الي: 》أن يذكر الاسم العام، ثم تذكر الصفة الخاصة في معرض

الاستدر الك و البيانه (r).

وقال تقي الدين السبكي: التعليق الحكم بإحدى صفتي الذات أو أحد

أوصافها يدل على نفي الحكم عن الصفة الأخرى《(๕).

وقال الآمدي: 》ذكر الاسم العام مقترناً بصفة خاصةهي(ْ).

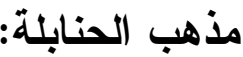

قال ابن قدامة المقدي: 》أن يخص بعض الأوصاف التي تطر أ وتزول

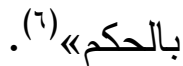

وقال ابن مفلح: 》أن يقترن بعام صفة خاصةه (`).

(1) أبو الوليد الباجي، أحكام الفصول، (ص (10)

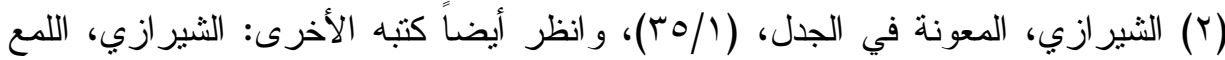

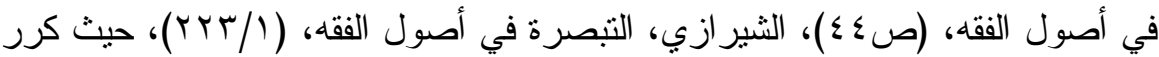

نفس التعريف.

(r) الغز الي، المستصفى في علم الأصول، (1) (ب0/1).

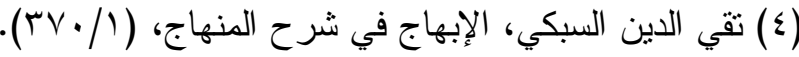

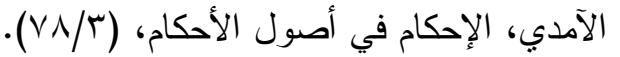

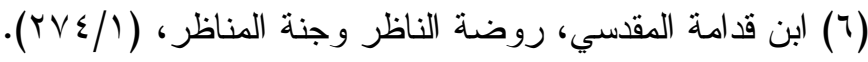

( ابن مفلح، أصول الفقه، (T/T)

(YNV/l)

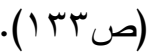




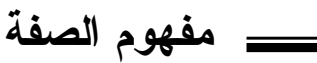

وقال عبد القادر بن بدران: اتعقيب ذكر الاسم العام بصفة خاصة في

$$
\text { معرض الاستخر الك و البيانه" ('). }
$$

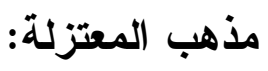

قال محمد بن علي بن الطيب البصري المعتزلي: 》هو أن بعلق الحكم

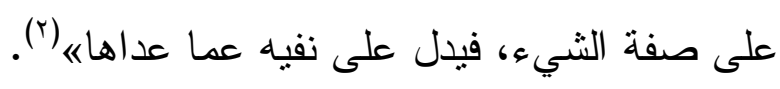

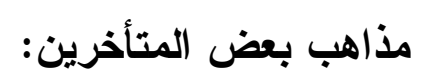

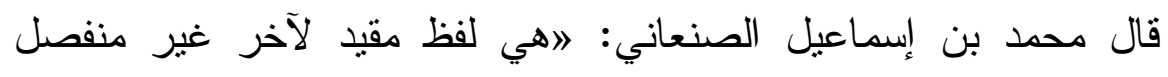

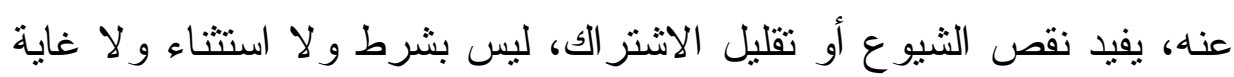
و لا عدده (r)

وقال محمد بن علي الثوكاني: لاهي تعليق الحكم على الذات بأحد

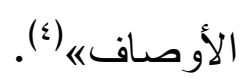

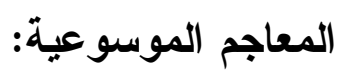

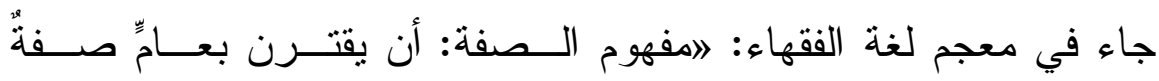

خاصةٌٌه (0).

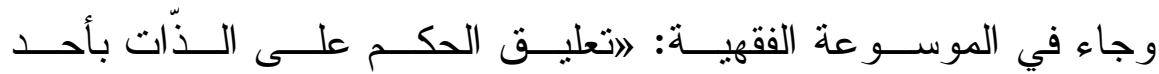

$$
\text { الأوصافه (ج). }
$$

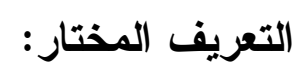

ويبدو للباحث من هذه التعريفات - على تماتلها - أن عماد مفهوم الصفة

$$
\text { عندهم أن يكون الحكم معلقاً بصفة، فيدل على الأخذ بخلافه. }
$$

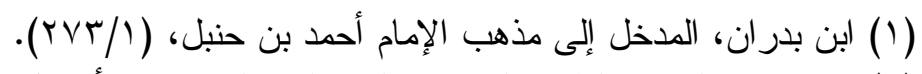

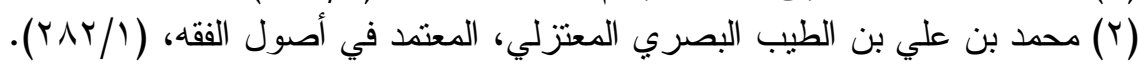

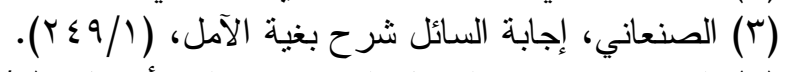

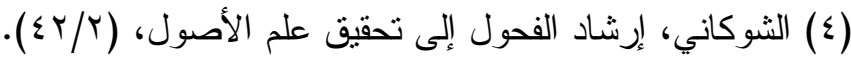

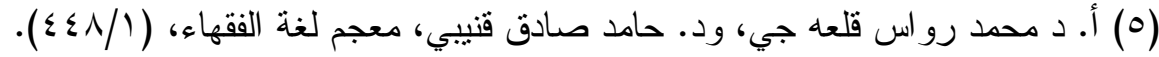

(7) وزارة الأوقاف و الثؤون الإسلامية بدولة الكويت، الموسوعة الفقهية الكويتية، مصطلح

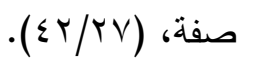




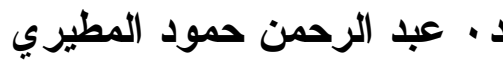

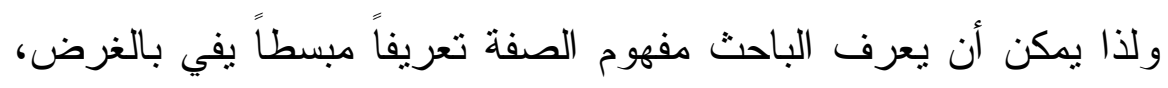

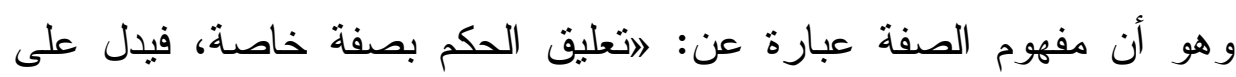
الأخذ بخلافهـ.

\section{المطلب الثاني : حجية 》مفهوم الصفة)؛:}

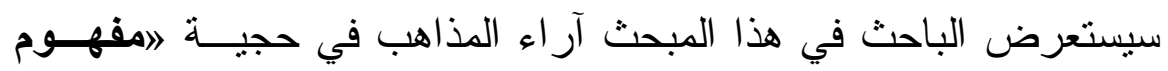

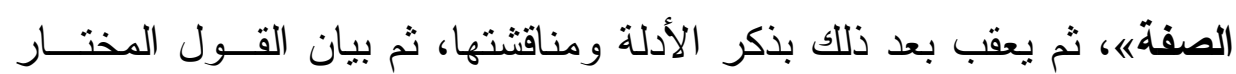

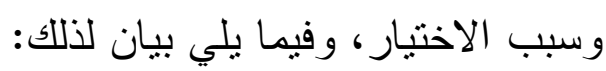

الفرع الأول: آراء الأصوليين في حجية لمفهوم الصفةهان:

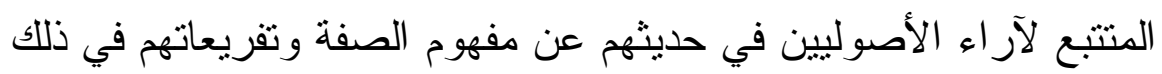

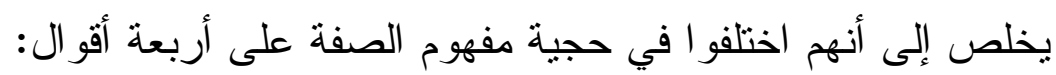
القول الأول: أن مفهوم الصفة حجة.

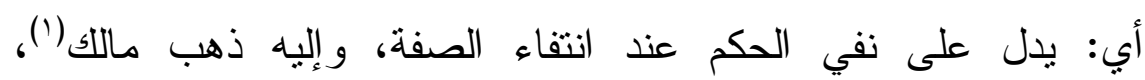

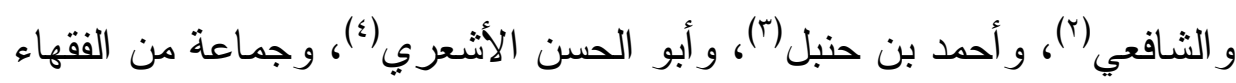

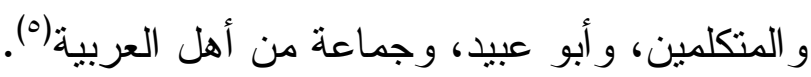

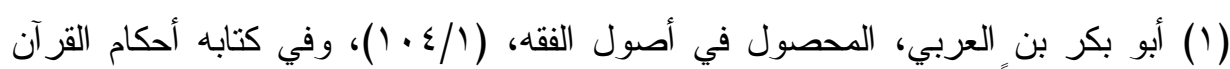

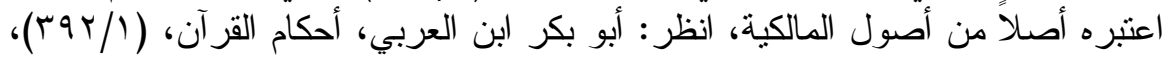

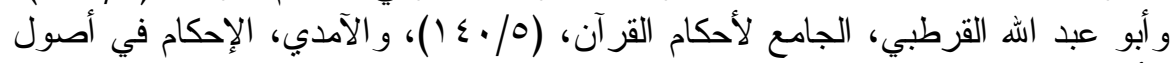

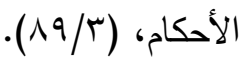

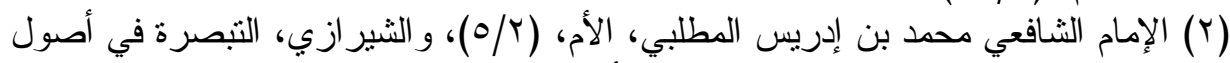

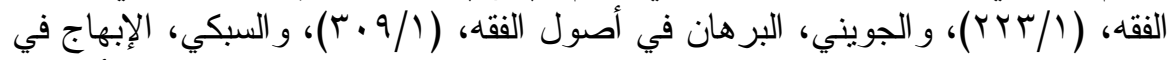

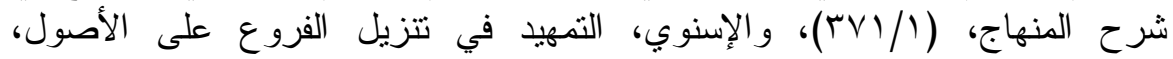
. $(r \leqslant 0 / 1)$

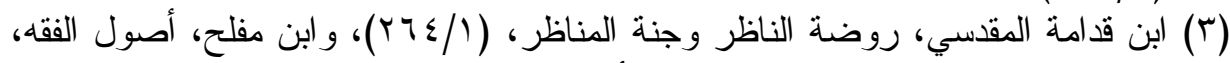

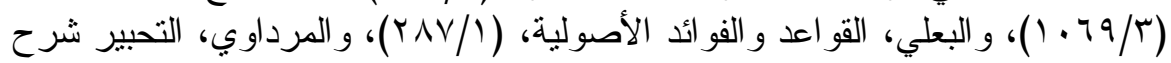

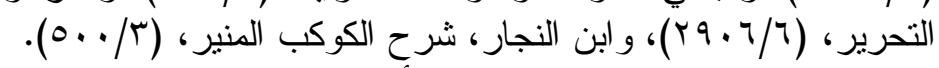

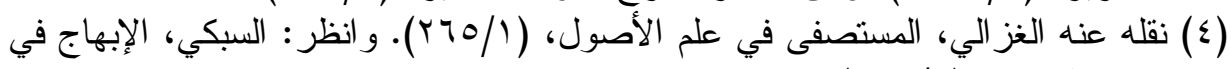

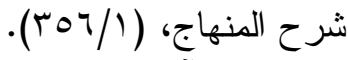
(0) نقله عنهم الآمدي، الإحكام في أصول الأحكام للآمدي، (Yr/T). 
القول الثاني: أن مفهوم الصفة ليس حجة.

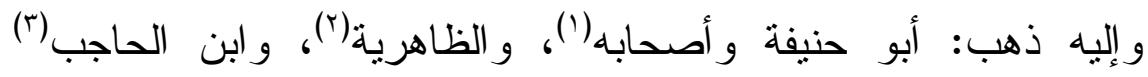

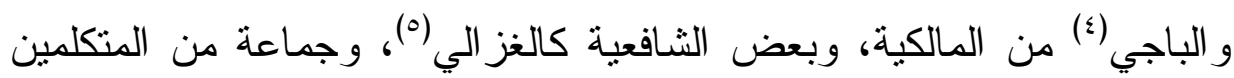

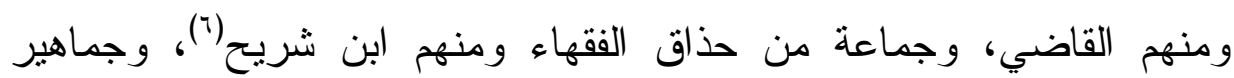
المعتزلة) (v)

القول الثالث: إذا كانت الصفات مناسبة للأحكام المنوطة بالموصوف بها، فذكر ها يتضمن انتفاء الأحكام عند انتفائها، وأن كل صفة لان يفهر منها مناسبة للحكم فالموصوف بها كالملقب بلقبه، والقول في تخصيصه بالذكر كالقول في تخصيص المسميات بألقابها.

$$
\begin{aligned}
& \text { و إليه ذهب: إمام الحرمين الجويني (^). }
\end{aligned}
$$

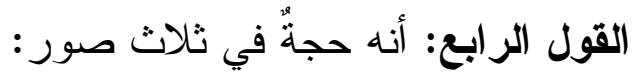

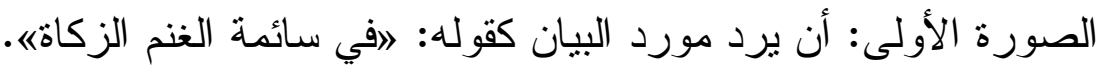

$$
\text { الصورة الثانية: أن برد مورد التعليم. }
$$

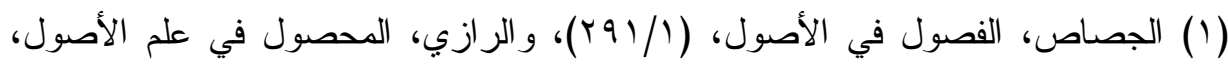

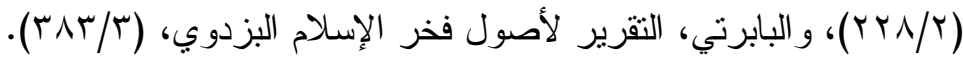

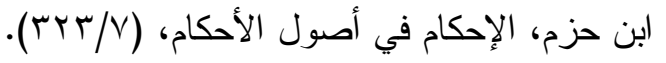

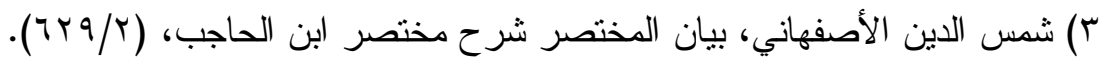

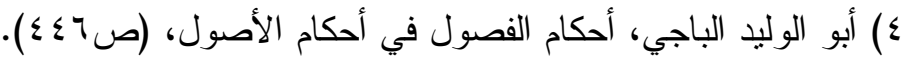

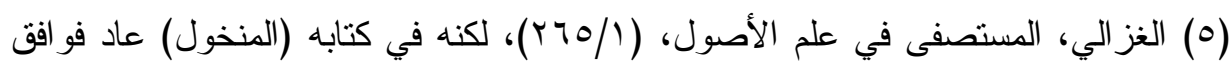

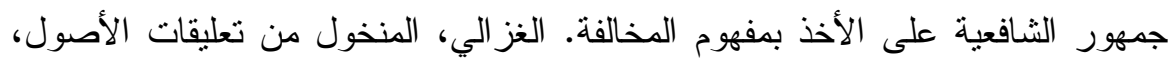

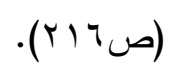

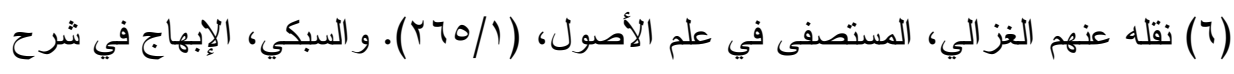

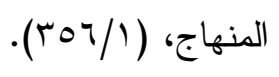

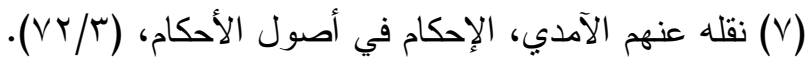

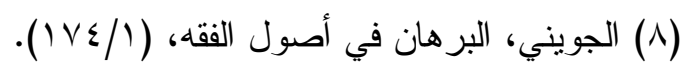

$$
\begin{aligned}
& -\wedge \varepsilon-
\end{aligned}
$$




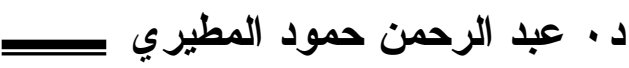

الصورة الثالثة: أو يكون ما عدا الصفة داخلاً تحت الصفة كالحكم

بالشاهدين، فإنه يدل على أنه لا يحكم بالثاهد الواحد؛ لأنه داخل تحت الثاهدين، و لا يدل على نفي الحكم فيما سوى ذللك.

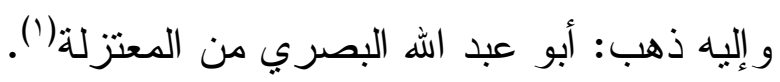

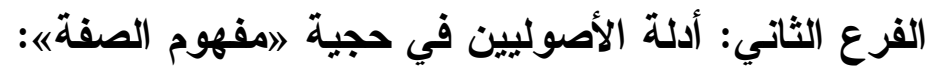

وبعد أن أتى الباحث على تفصيل المذاهب في حجية 》مفهوم الصفةه فلا بد من ذكر أدلة كل مذهب، و التنبيه على ما فيها، ثم يذكر بعد ذلك القول

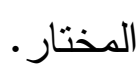

\section{أدلة القول الأول:}

استدل أصحاب القول الأول- وهم جمهور أهل العلم - القائلون: إن الن مفهوم الصفة حجة، و إنه يدل على نفي الحكم عند انتفاء الصفة، بأدلة نقلية، ولغوية، و عقلية، فمنها:

الاليل الأول: ما جاء في صحيح مسلم عن عبد الله بن الصامت عن أبي ذر -رضي الله عنه- أنه قال: قال رسول الله -صلى الله عليه وسلم-: إإذا قام أحدكم يصلي فإنه بستره إذا كان بين يديه مثل آخرة الرحل، فإذا لم يكن بين يديه مثل آخرة الرحل، فإنه يقطع صلاته الحمار والمرأة و الكلب الأسود إن.

قلت" -أي: عبد الله بن الصامت-: يا أبا ذر ما بال الكلب الأسود من

الكلب الأحمر من الكلب الأصفر؟ قال: يا ابن أخي سألتُ رسول الله -صلى بـ دال الله عليه وسلم - كما سألتتي فقال: 》الكلب الأسود شيطانه (؟).

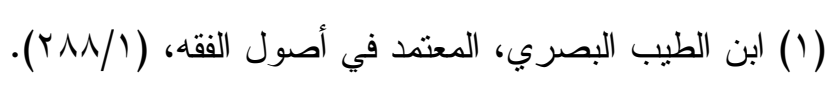

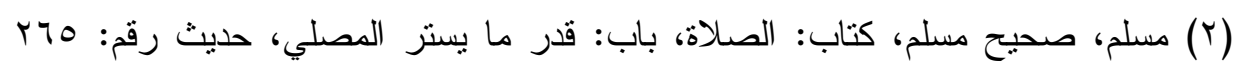




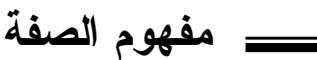

ففهم التابعي عبد الله بن الصامت و الصحابي أبو ذر الغفاري من تعليق الحكم على الدوصوف بالسواد انتفاءه عما سواه، والنبي -صلى الله عليه

وسلم - أقره على ذلك، فلل أن مفهوم الصفة معتبر .

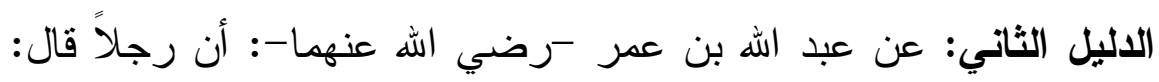

يا رسول الله، ما يلبس المحرم من الثياب؟ قال رسول اله -صلى الهه عليه

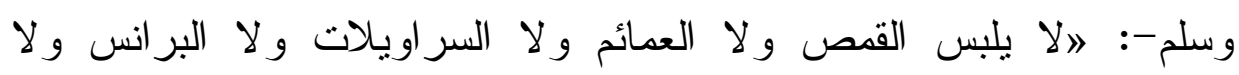

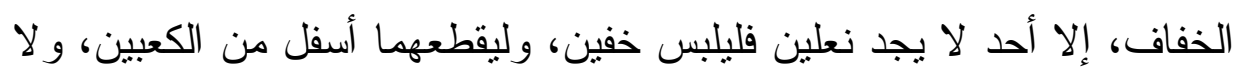

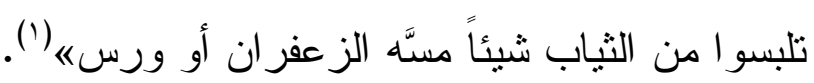

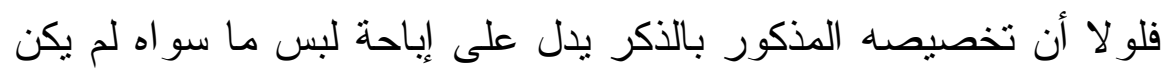

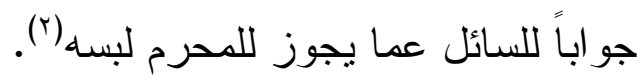
الاليل الثالث: العرب يعتبرون القيدَ في تخاطبهم، فإذا قال العربي لوكيله:

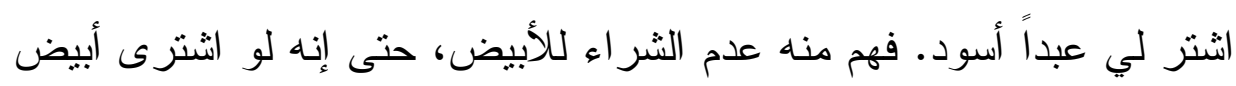
لم الم يكن ممتثلاً.

وكذلك إذا قال الرجل لزوجته: أنت طالق إن دخلت الدار ـ فهم منه انتفاء

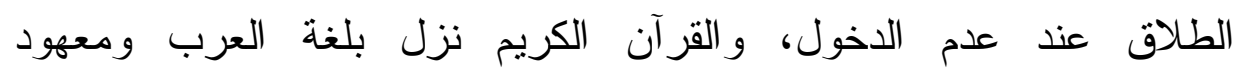
خطابهم (r).

الاليل الرابع: أنه لو كان حكم السائمة و المعلوفة سو اء في وجوب الزكاة، لما كان لتخصيص السائمة بالذكر فائدة، وكان الكلام لغواً، بل كان النهان ملغزاً

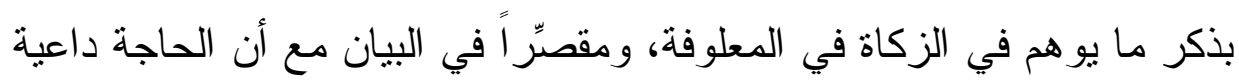

(1) البخاري، صحيح البخاري، كتاب: الحج، باب: ما لا يلبس الدحرم من الثياب، حديث

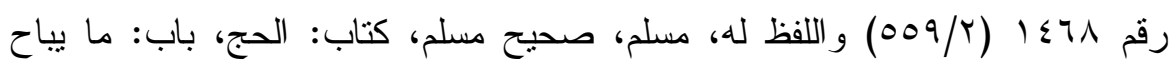

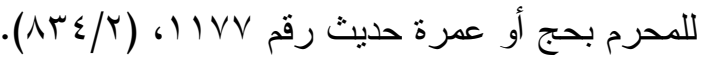

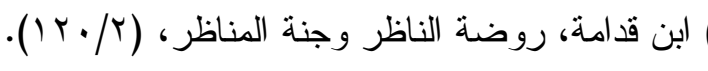

$$
\begin{aligned}
& \text { (Y) الغز الي، المستصفى من أصول الفقه، (Y/ (199) (1). } \\
& -\wedge 7-
\end{aligned}
$$




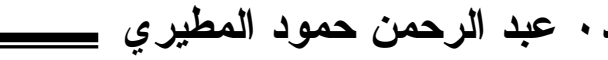

إليه، وذللك على خلاف الأصل، وحيث امتتع ذلك دل على أن فائدة التخصيص بذكر السائمة نفي الزكاة عن المعلوفة.

كما أن ربط الحكم بالوصف يومئ إلى علّية ذلك الوصف، فمتى انتفت

العلة انتفى المعلول(').

أدلة القول الثاني:

استذل أصحاب القول الثاني -وهم الحنفية و الظاهرية ومن وافقهم من

$$
\text { الناقين لمفهوم الصفة- بما يلي: }
$$

الاليل الأول: أنه يحسن الاستفهام عن ما قُبِّد بالصفة، فلو قال: من

ضربك عامداً فاضربه، حَسُن أن تقول: فإن ضربني خاطئًا هل أضربه؟ ولو دلَّ على النفي لما حسن الاستقهام فيه كالمنطوق.

وأجيب عليه: إن قولكم: يحسن الاستفهام عنه ممنوع، وأما إذا قال: من الن إنها:

ضربك متعمداً فاضربه، فلا يحسن أن يقال: من ضربني خاطئًاً هل أضربه؟

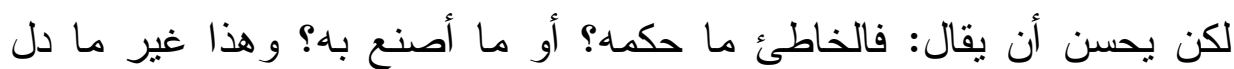
عليه الخطاب.

ولو سلمنا بما قلتم فيحسن الاستفهام ليستفيد التأكيد في معرفة الحكم، كما يحسن الاستفهام في بعض صور العموم؛ فيكون حسن الاستفهام لطلب الأجلى و الأوضح؛ لكون دلالة الخطاب ظاهرة ظنية غير قطعية(؟).

(1) الآمدي، الإحكام في أصول الأحكام، (ب/1)، و البيضاوي، منهاج الوصول في علم

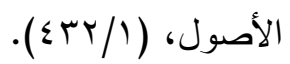

(ץ) انظر للتفصيل و المناقتشة: النسفي، كثف الأسرار ، (1// (1))، وابن أمير الحاج، التقرير

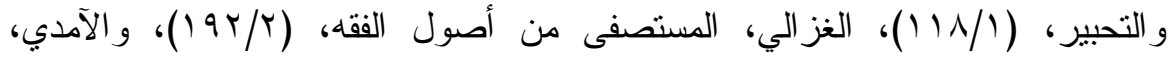

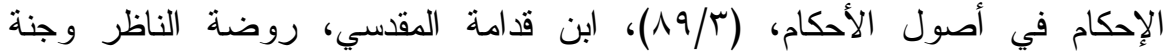

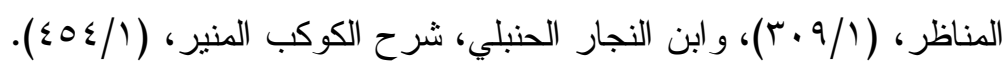




\section{=}

اللاليل الثاني: أن التخصيص للمذكور بالذكر قد يكون لفائدة سوى

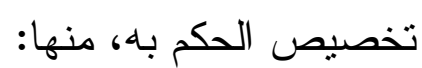

الفائدة الأولى: نوسعة مجاري الاجتهاد؛ لينال المجتهد فضيلته.

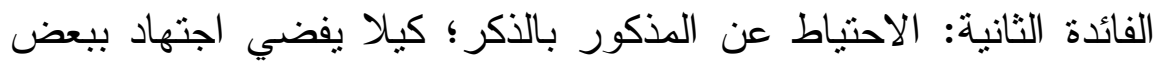

الناس إلى إخر اجه عن عموم اللفظ بالتخصيص. الفائدة الثالثة: تأكيد الحكم في المسكوت؛ لكون الكون المعنى فيه أقوى كالتنبيه. الفائدة الر ابعة: معان لا يطلع عليها. فلا سبيل إلى دعوى عدم الفائدة بالتحكم (').

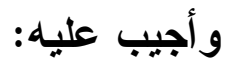

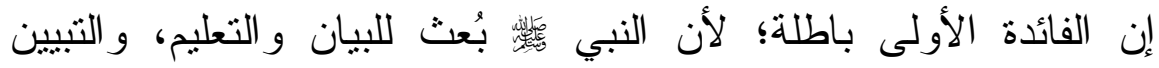

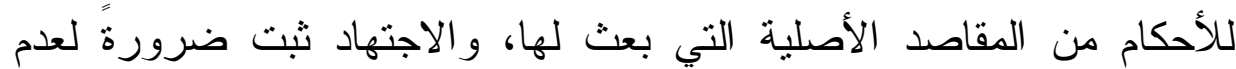
إمكان بناء كل الأحكام على النصوص، فلا يظن أن النبي -صلى الله عليه وسلم- ترك ما بعث له لتوسعة مجاري الضرورات، ثم يفضي إلى محذور و هو نفي الحكم في الصورة التي هو ثابت فيها.

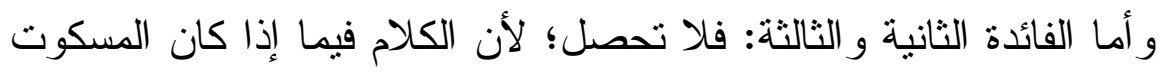

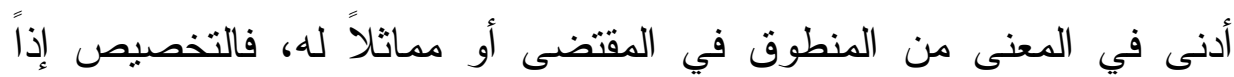
يكون بعيداً، وأما إذا كان المسكوت أعلى في المعنى فهو التتبيه.

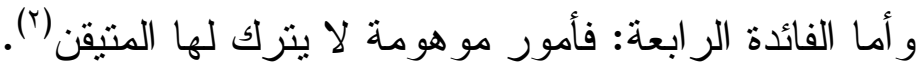

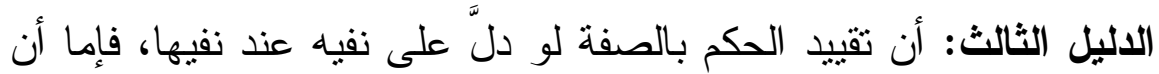
يعرف ذلك بالعقل أو النقل.

(1) الجصاص، الفصول في الأصول، (19/1/(1)، و البابرني، الثقرير لأصول فخر الإسلام

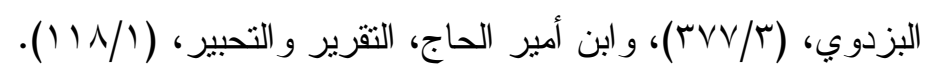

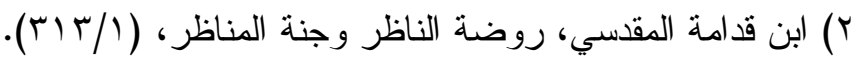




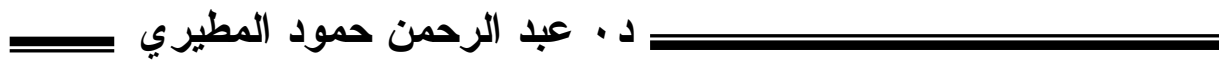

و العقل لا مجال له في اللغات، و النقل إما متواتر و آحاد، و لا سبيل إلى لـى لإن

التواثر، والآحاد لا يفيد غير الظن، وهو غير معتبر في إثبات اللغات؛ لأن الحكم على لغة ينزل عليها كلام الله تعالى ورسوله -صلى اله عليه وسلمبقول الآحاد مع جواز الخطأ، و الغلط عليه يكون ممتنعاًً ('). وأجيب عليه: إنه لو سلمنا أن ذلك لا يعرف إلا بالنقل، فلا نسلم امتتاع

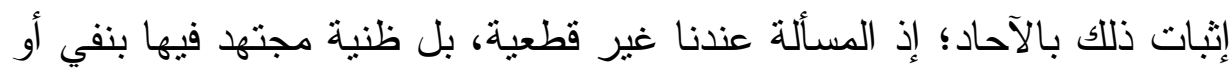

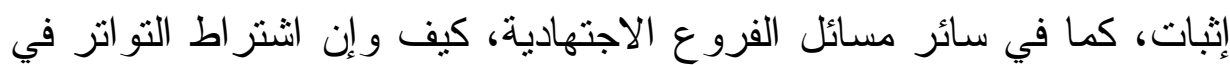
إثبات اللغات: إما أن يكون في كل كلمة ترد عن أهل اللغة، أو في بعضها دون بعض، و القول بالتفصيل تحكم غير دعقول، كيف و أنه لا قائل به؟!

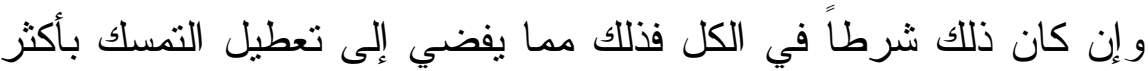

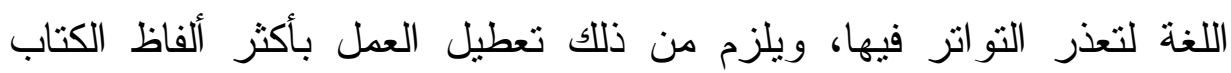
و السنة و الأحكام الثرعية؛ ولهذا كان العلماء في كل عصر يكتقون في إثبات الأحكام الثرعبة المستندة إلى الألفاظ اللغوية بنقل الآحاد المعروفين بالثقة و المعرفة، كالأصمعي، و الخليل الفر اهيدي، وأبي عبيدة، وأمثالهم (؟).

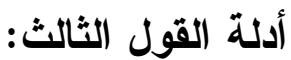

قدمنا عند ذكر المذاهب أن إمام الحرمين الجويني الثنافعي يفصل بين الصفات مناسبة للأحكام المنوطة بالموصوف بها، فذكُرْها بتضمن انتفاء الأحكام عند انتفائها، و الصفات التي لا يفهم منها مناسبة للحكم فالموصوف بها لهات كالملقب بلقبه، والقول في تخصيصه بالذكر كالقول في تخصيص المسميات بألقابها.

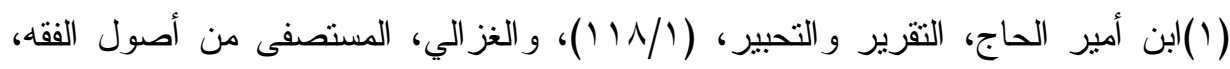

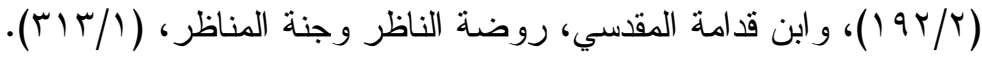

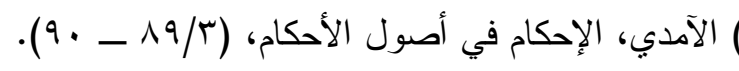




\section{مفهوم الصفة}

ولقد استنل على ذلك باللغة: فبيّن أن أهل اللغة العربية قرروا أن

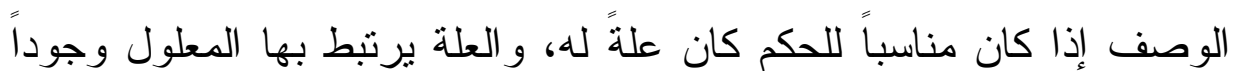
و عدماً، فيوجد الحكم بوجوده، وينتفي بانتفائها. أما إذا كان الوصف غير مناسب: فمعنى ذللك أنه لا ارتباط بينه وبين

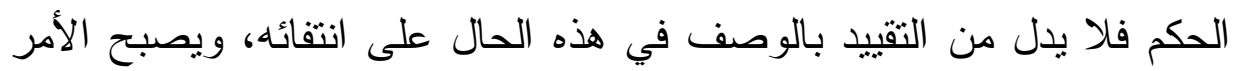

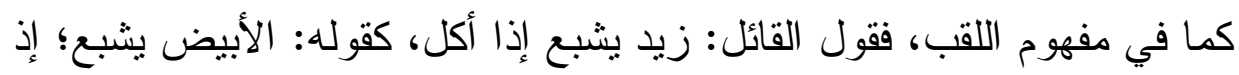

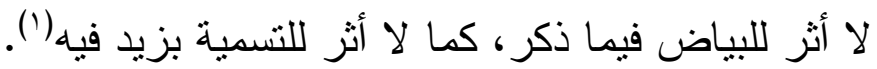

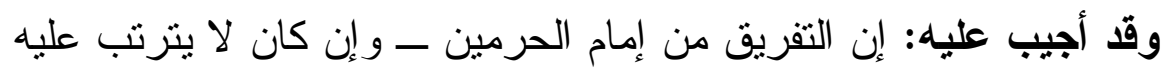
كبير أثر في الأحكام ــ فإنه مردودٌ بما أثتبه أهل اللغة و وعلى رأسهم إمام أهل

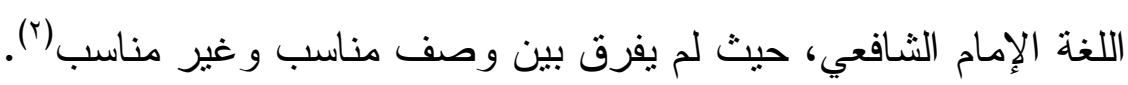

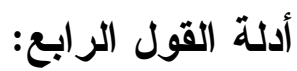

قدمنا عند ذكر المذاهب أن أبا عبد الله البصري يرى أن مفهوم الصفة

$$
\text { يكون حجة في ثلاث صور : لمنا }
$$

الصورة الأولى: أن برد مورد البيان.

الصورة الثانية: أن يرد مورد التعليم. الصن مورد اليان.

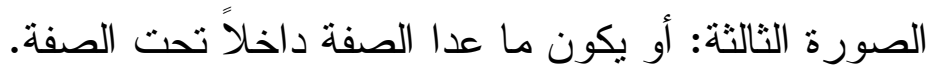

$$
\text { و لا بدل على نفي الحكم فيما سوى ذلك (َ)". }
$$

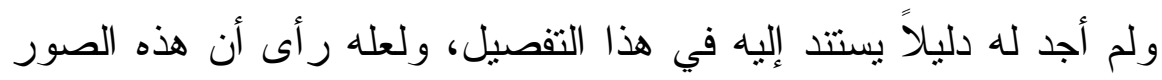

الوصف الدذكور فيها مناسباً للحكم الذي أعطي للمنطوق، وغيره فلا.

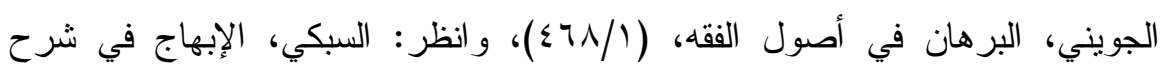

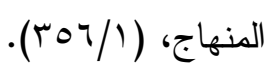

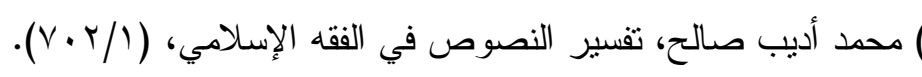

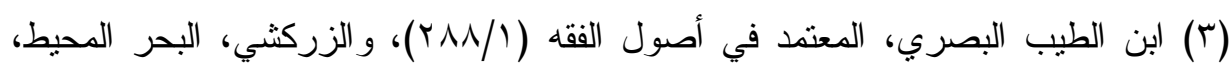




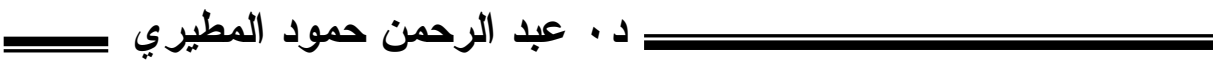

ويكفي على الرد علبه ما أجيب في رد استدلالات القول الثاني و القول

الفرع الثالث: القول المختار في حجية 》مفهوم الصفةه:

يرى الباحث بعد عرض آراء المذاهب وذكر أدلتهم أن القول المختار هو

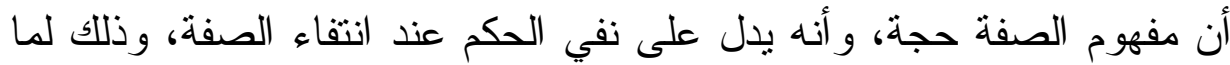

يلي (')

الدليل الأول: أن أهل اللغة فرقو ابين الخطاب المطلق و المقيد بالصفة،

كما فرقو ا بين الخطاب المرسل وبين المقيد بالاستثناء، و الاستثناء يدل على أن

حكم المستنثى على خلاف حكم المستثنى منه، فكذلك الصفة. الاليل الثاني: أنه إذا كان التخصيص بذكر الصفة يدل على الحكم في

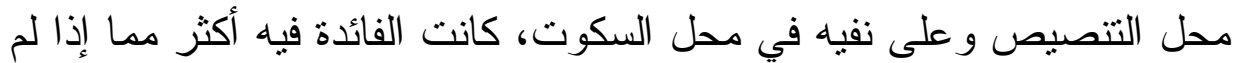
يدل؛ فوجب جعله دليلاً عليه.

الدليل الثالث: أن التعليق بالصفة كالتعليق بالعلة، و التعليق بالعلة يوجب نفي الحكم لانتفاء العلة، فكذلك الصفة.

الاليل الرابع: أن الصحابة -رضي الله عنهم- اعتبروا مفهوم الصفة؛

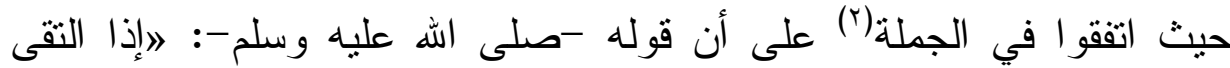

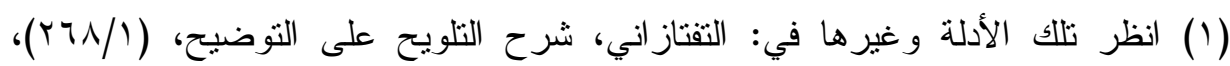

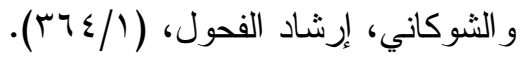

(Y) نقل هذا الاتفاق النووي في شرحه على صحيح مسلم فقال: ارفالجمهور من الصحابة

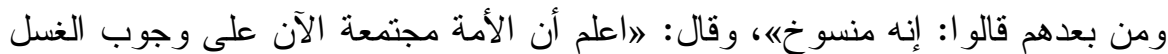

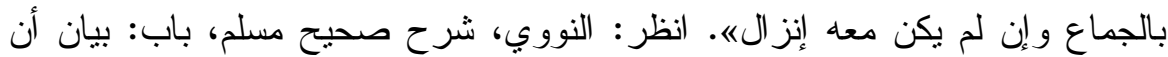

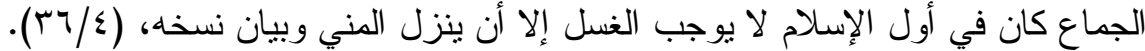




\section{=}

الختانان فقد وجب الغسله(')، ناسخّ لقوله -صلى اله عليه وسلم-: (الماء من

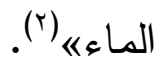

ولو لا أن قوله -صلى الله عليه وسلم-: الالماء من الماءهـ يدل على نفي

الغسل من غير إنز ال لما كان نسخاً له.

ويرى الباحث أن أدلة الحنفية ومن و افقهم منتفية؛ لأن الجمهور القائلين

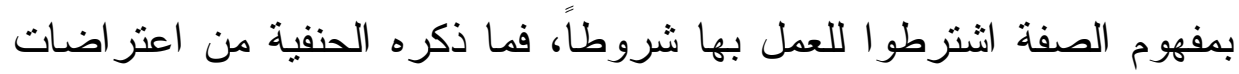

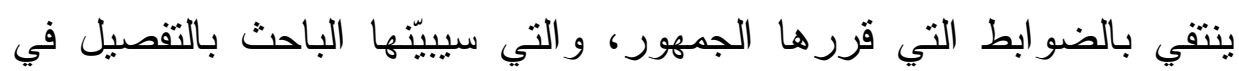
المبحث النالي.

\section{$* *$}

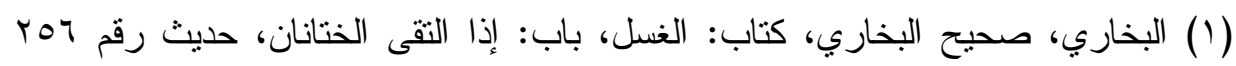

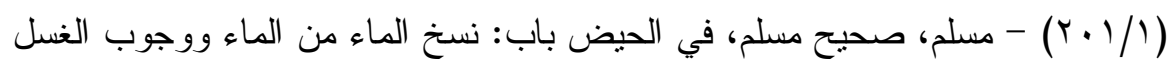

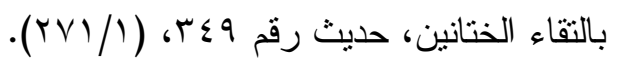

(Y) مسلم، صحيح مسلم، كتاب الحيض، باب: إنما الماء من الماء، حديث رقم باء؟ب،

. (YTQ, TYY/Y) 


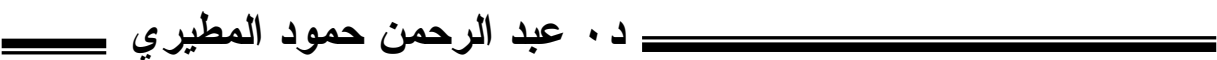

المبحث الثاني

شروط 》مفهوم الصفةة) وصوره

المطلب الأول: شروط 》مفهوم الصفة):

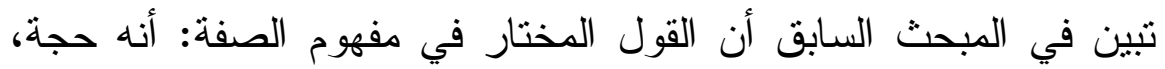

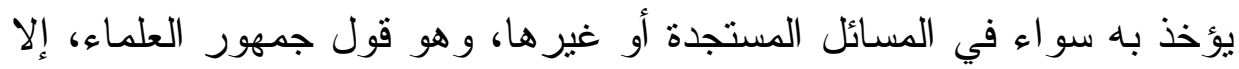

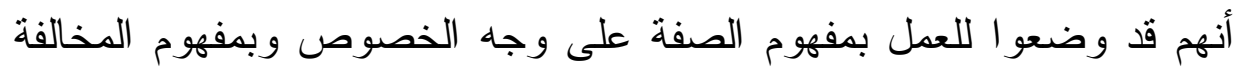

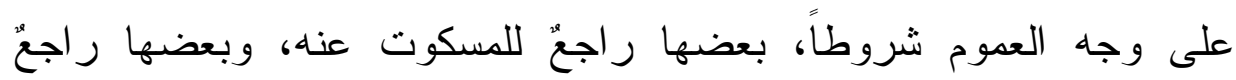
للمذكور ، فإليك هذه الثروط دفصلة:

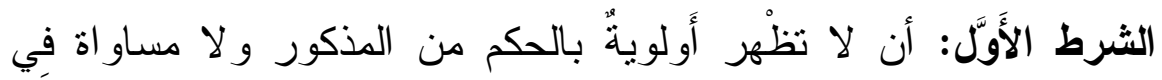

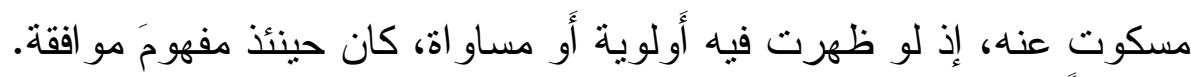

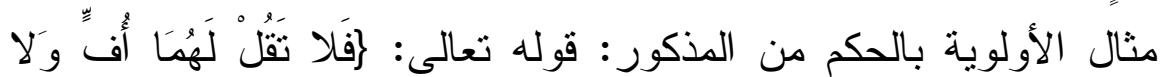

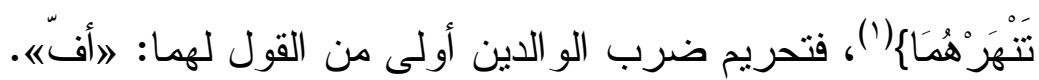

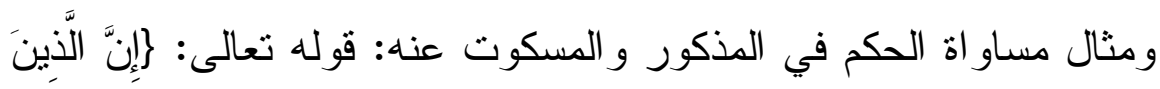

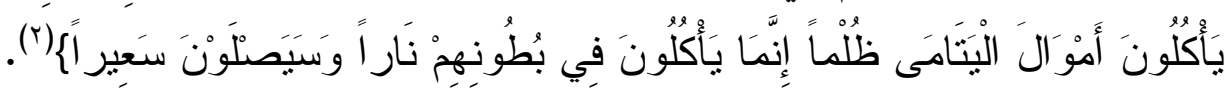

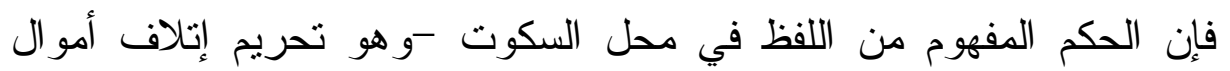
اليتامى - مو افق" للحكم الدفهوم في محل النطق وهو أكل أمو الهم.

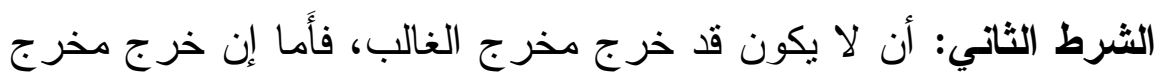

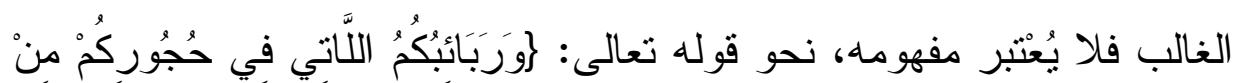

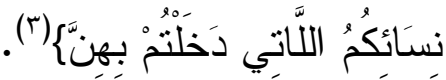

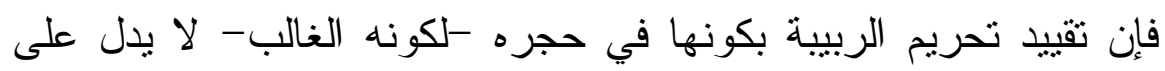
حلِ الربيبة التي ليست في حجره.

(1) سورة الإسر اء: من الآية:بr. (1)

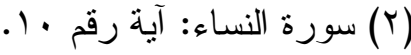

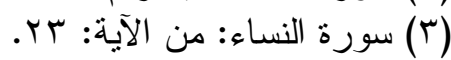




\section{مفهوم الصفة}

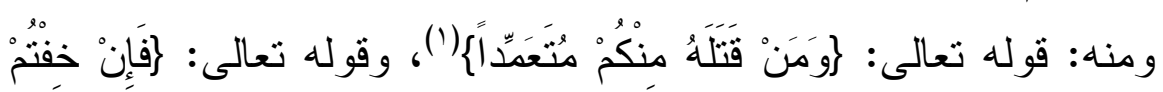

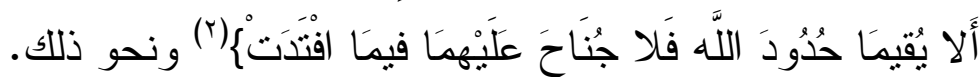

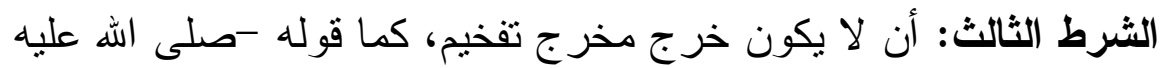

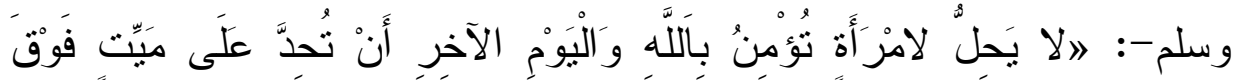

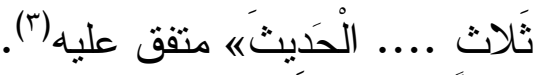

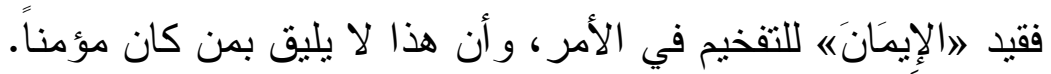

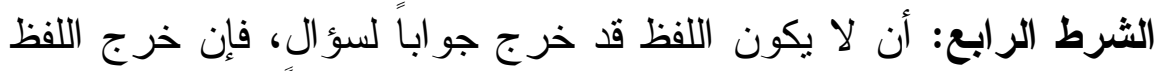
جو اباً لسؤ ال لم يعمل بمفهومه.

مثل أن يُسأل النبي -صلى الهُ عليه وسلم--: هل في الغنم السائمة زكاة؟ فلا يلزم من جواب السؤ ال عن إحدى الصفتين أن يكون الحكم على الضد في الأخرى، لظهور فائدة في الذكر غير الحكم بالضد.

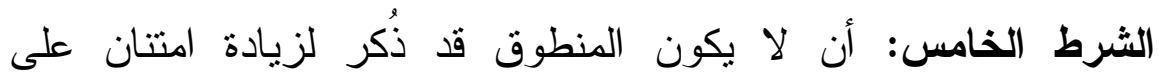

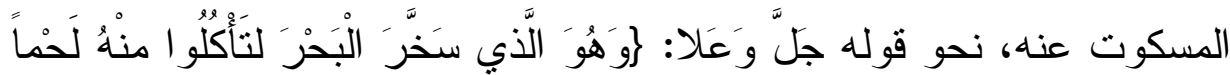

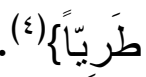
فلا يدل على منع القديد(0) من لحم ما يؤكل مما يخرج من البحر كغيره.

$$
\begin{aligned}
& \text { (1) سورة المائدة: من الآية: } 90 .
\end{aligned}
$$

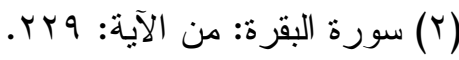

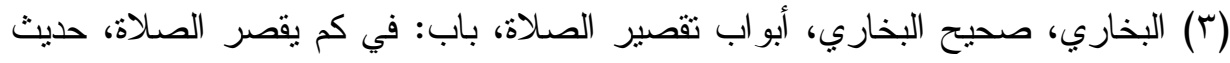

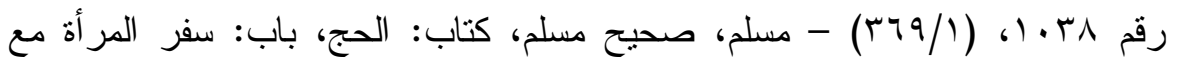

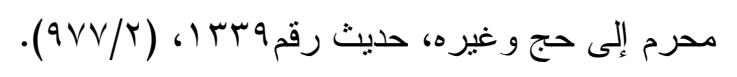

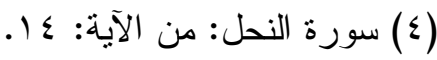

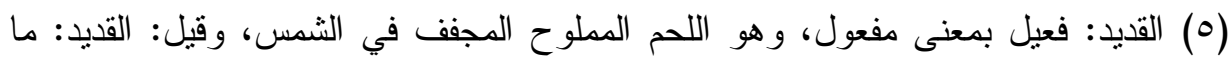

قطع من اللحم وشرر ، وقيل: هو ما قطع منه طو الأ. =

$$
-9 \leqslant-
$$




\section{د. • عبد الرحمن حمود المطيري}

الثرط السادس: أن لا يكون المنطوق قد خرج لبيان حكم حادثة اقتضت بيانَ الحكم في المذكور، كما روى سلمة بن الحبق -رضي الله عنه-: أَنَّ

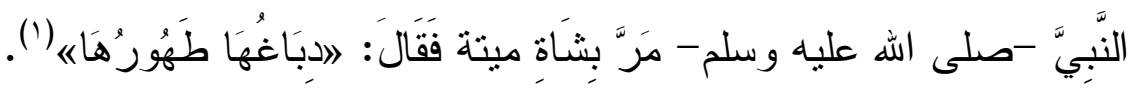
إذ القصد الحكم على تللك الحادثة، لا النفي عما عداها.

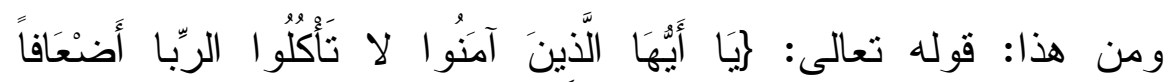

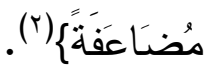

فإنه ورد على ما كانو ايتعاطونه في الآجال: أنه إذا حلَّ الدينُ يقولون للمديون: إما أن تعطي، و إما أن تزيد في الدين، فيتضاعف بذلك مضاعفة

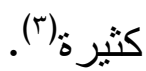
الشرط السابع: أن لا يكون المنطوق قد ذكر لتقدير جهل المخاطب به، دون جهله بالمسكوت عنه، كأن يكون المخاطب يعلم حكم المعلوفة ويجهل حكم السائمة، فيذكر له. الشرط الثامن: أن لا يكون المنطوق قد ذُكر لرفع خوف ونحوه عن المخاطب، كقولك لمن يخاف من نرك الصلاة الموسعة: تركُها في أول الوقت

فليس مفهومه عدم الجوازِ فِي باقي الوقت، وهكذا إلى أن يتضايق.

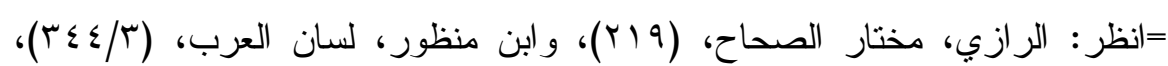

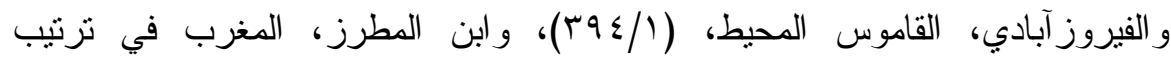

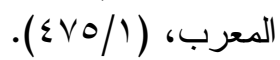

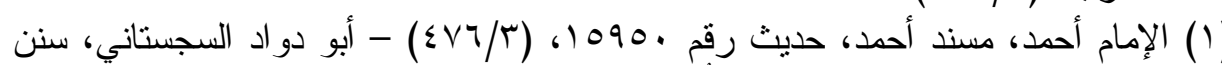

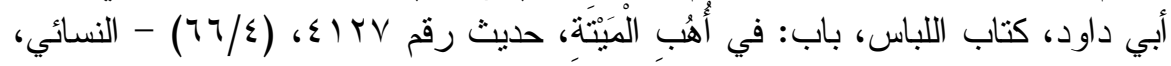
السنن الكبرى، حديث رقم

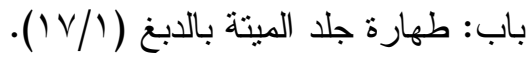

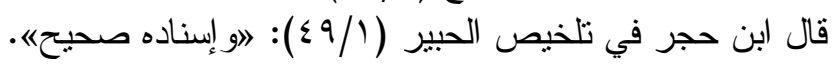

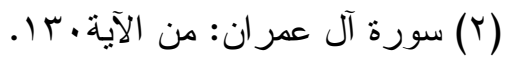

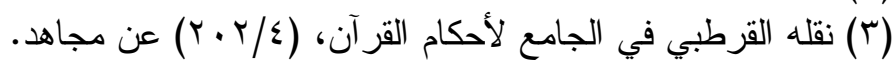




\section{=}

الثرط التاسع: أن لا يكون المنطوق قد عُلّق حكمه على صفة غير

مقصودة.

فإن كانت الصفة غير مقصودة فلا مفهوم، كقوله سبحانه وتعالى: 3لا

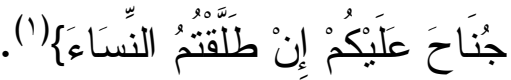

أر اد نفي الحرج عمن طلق ولم يمس، و إيجاب المتعة تبعاً.

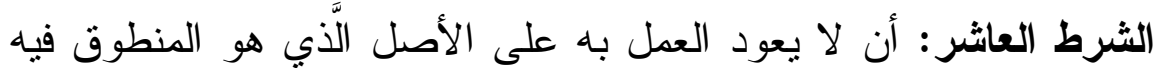

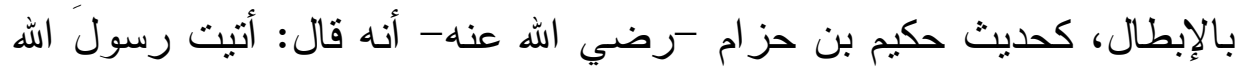

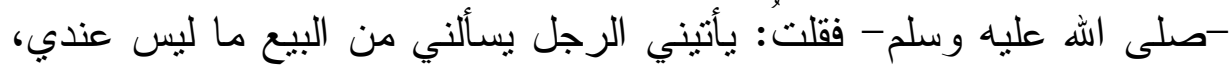

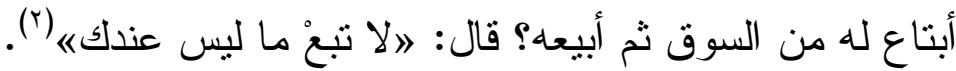

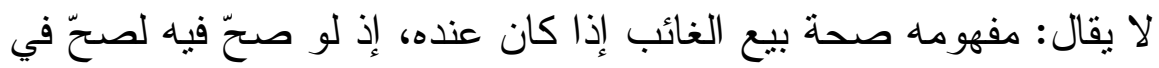

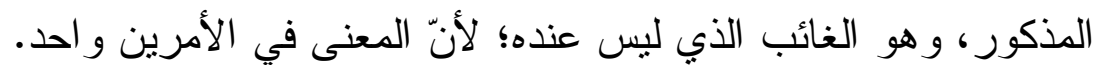

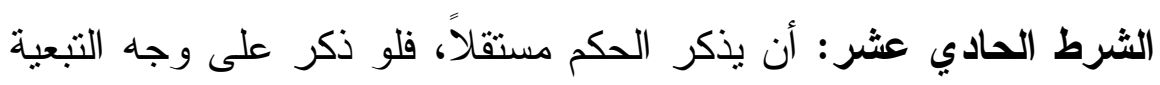

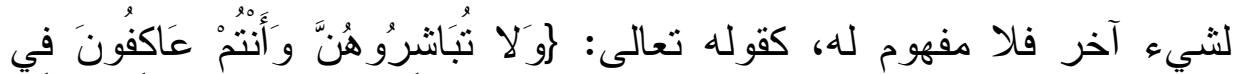
الْمَسَاجد

$$
\text { (1) (1) سورة البقرة: من الآية: بسזr. }
$$

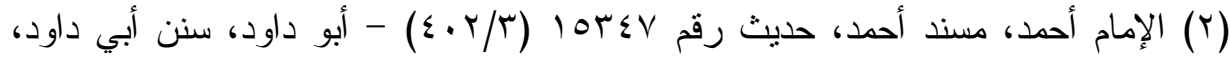

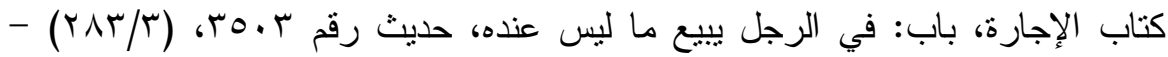

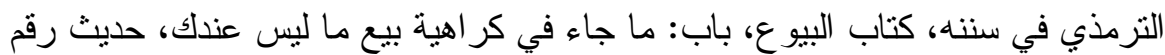

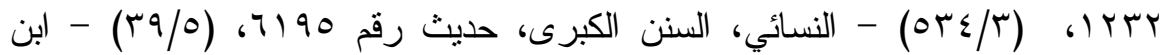

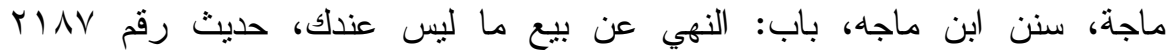
(VTr/T)

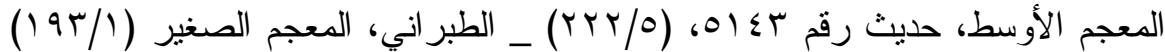

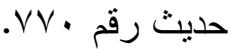

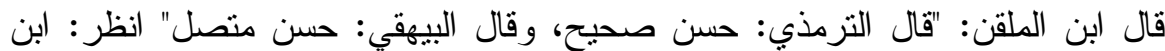

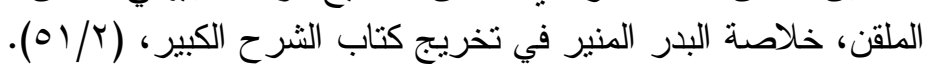

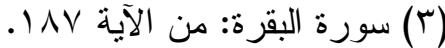




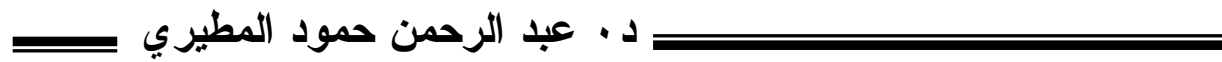

فإن قوله: (فِي الْمَسَاجدئ لا مفهوم له؛ لأن المعتكف ممنوع من المباشرة مطلقا.

الشرط الثاني عشر: أن لا يظهر من السياق قصد التعميم، فإن ظهر فلا

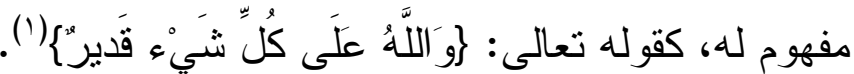
فالآية لا مفهوم لها؛ لأن الله سبحانه قادر على المعدوم و الممكن. والضابط لهذه الثروط وما في معناها والتي ذكرها علماء الأصول

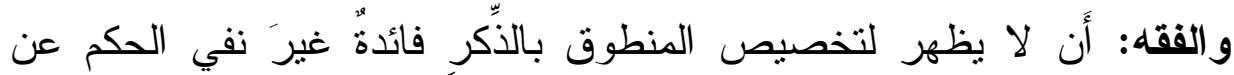

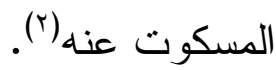

المطلب الثاني: صور 》مفهوم الصفة؛ ليس المر اد بالصفة عند الأصوليين (النعت) فقط - كما عند النحاة - بل أوسع من ذلك:

يقول الشوكاني: او المراد بالصفة عند الأصوليين: تقييد لفظ مشترك المعنى بلفظ آخر يختص ببعض معانيه، ليس بشرط و لا غاية. و لا يريدون به النعت فقط وهكذا عند أهل البيان، فإن المراد بالصفة عندهم هي المعنوية لا النعت، و إنما يخص الصفة بالنعت أهل النحو فقطه ().

(r) انظر تلك الثروط وشرحها ومزيد الأمتلة عليها: السبكي، الإبهاج في شرح المنهاج،

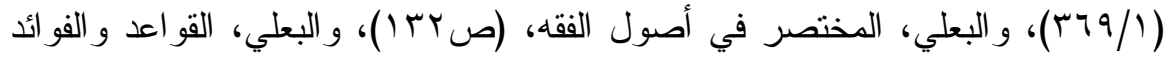

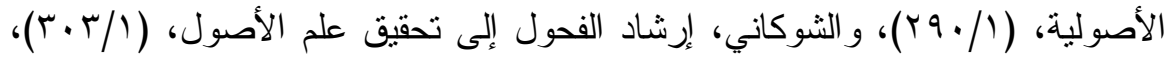
و ابن بدران، المدخل إلى مذهب الإمام أحمد بن حنبل، (صع Y F).

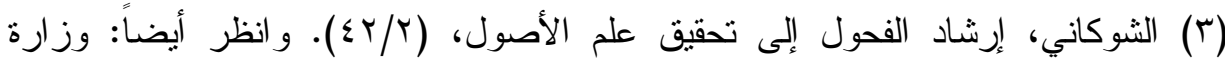

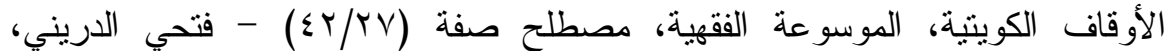

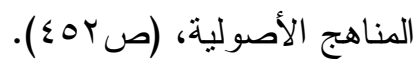




\section{مفهوم الصفة - م}

وقال الصنعاني: او اعلم أن حقيقة الصفة ما وضع ليدل على الذات التهات

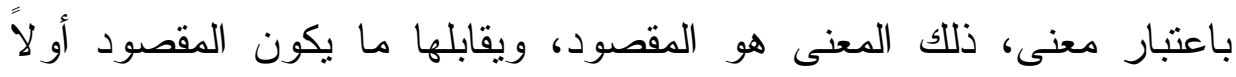

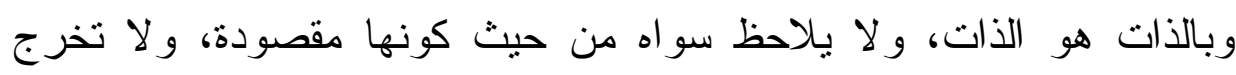

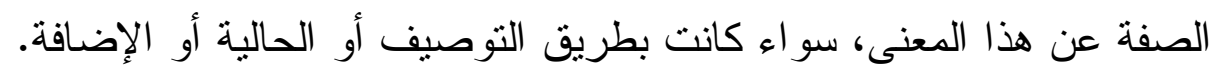

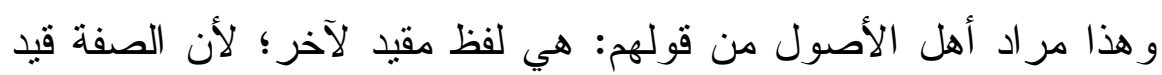

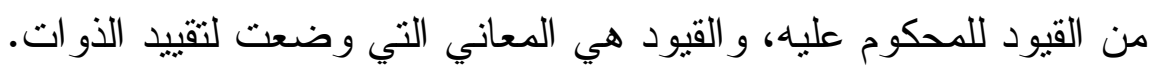

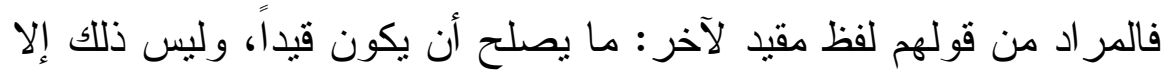
فيما يدل على الذات باعتبار معنى هو الدقصود.

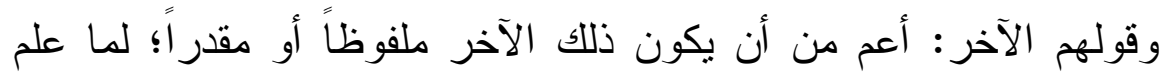

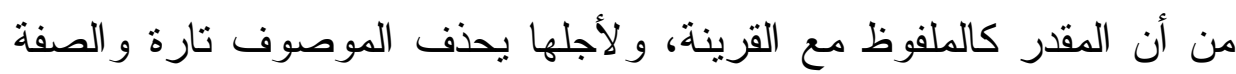

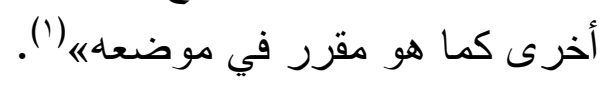

وفيما يلي صور مفهوم الصفة التي ذكر ها الأصوليون و الفقهاء، و التي لا لا تختص بالنعت فقط:

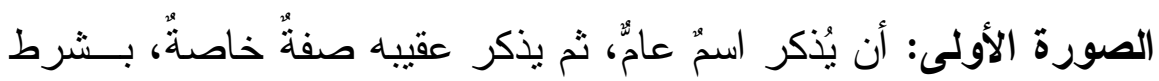
أن يكون ذللك في معرض الاستدر الك و البيان. مثاله: حديث أنس بن مالك -رضي الله عنه- عن رسول الله -صلى الله

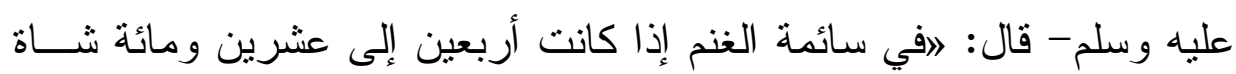

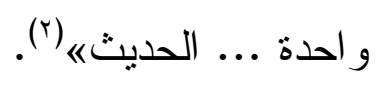

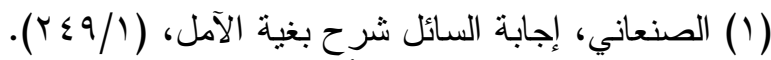

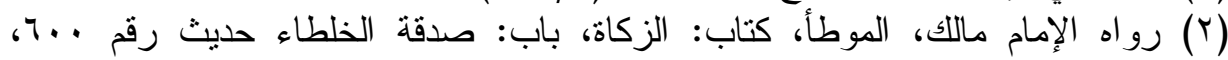

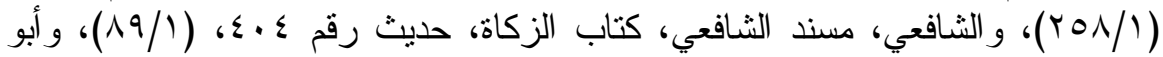

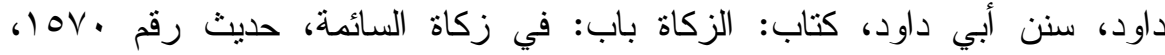

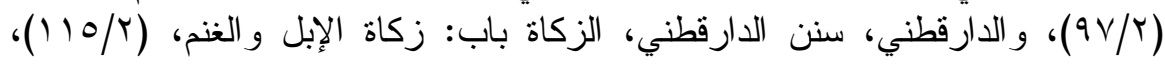

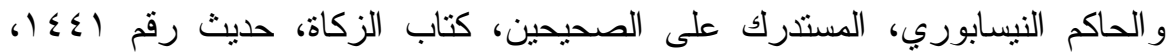
. (0 $0 \leqslant 1 / 1)$ قال الدارقطني: " إسناده صحيح وكلهم نقات ". انظر : الدارقطني، سنن الدارقطني، 


\section{د. • عبد الرحمن حمود المطيري}

فلفظ 》سائمةهُ عامٌ يشمل الغنم و البقر و الإبل، فاستدرك عموم ذلك بتقييد السائمة بإضافتها إلى الغنم، فقال: 》في سائمة الغنمه، وبين أن ذلك هو المر اد

$$
\text { من عموم السائمة. }
$$

الصورة الثانية: تعليق الحكم على صفة لا تستقر، بــلـ تطـــر أ أحيانــاً،

$$
\text { وتزول أحياناً أخرى. }
$$

مثاله: حديث ابن عباس -رضي الله عنهما-، أن النبي -صلى الله عليه

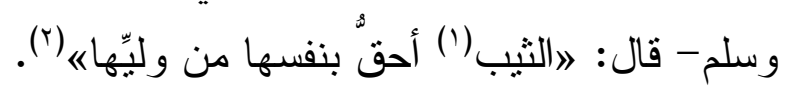

فهنا اقترن الحكم -وهو كون المرأة أحق بنفسها من وليها- بوصف وهو وهو

$$
\text { الثيوبة، وهو وصف طارئ على المر أة. }
$$

الصورة الثالثة: أن يذكر قسمان، ويذكر حكمُ أحد القسمين، فإن هذا يدل

على انتقاء ذلك عن القسم الآخر ، وهو الذي بسمى لمفهوم التقبيمهـ.

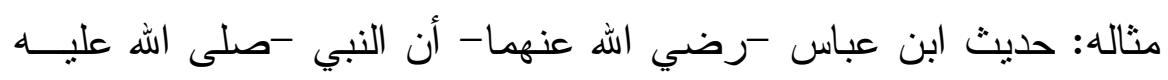

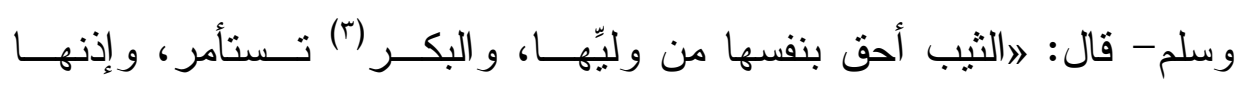

$$
\text { سكوتهاه (§) }
$$

(1) الثيب منٍ النساء: هي من انفضت بكارتها، وقد يُطلق على البالغة و إن كانت بكراً مجازاً

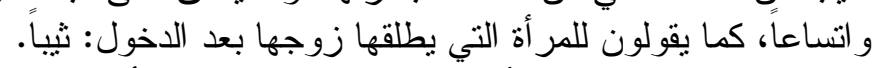

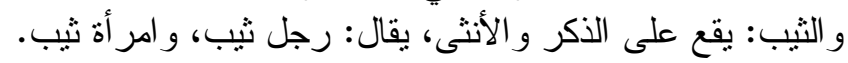

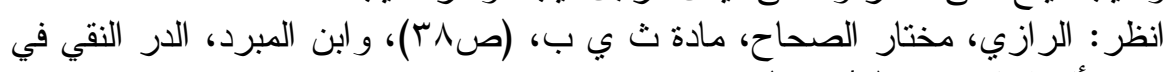

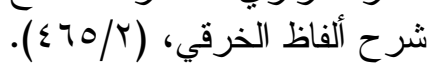

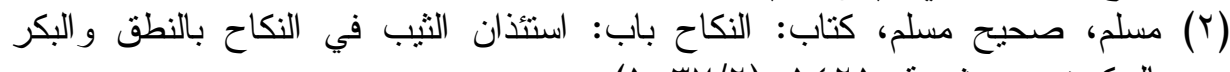

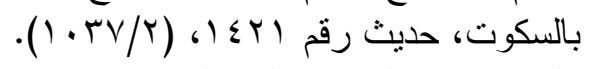

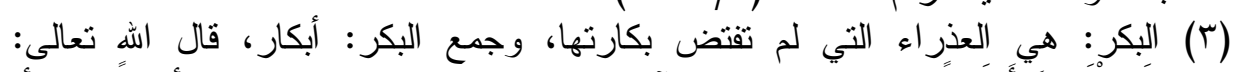

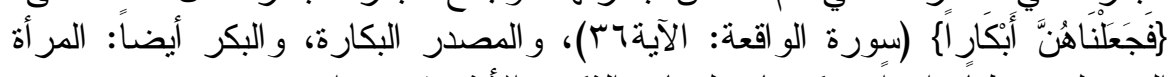

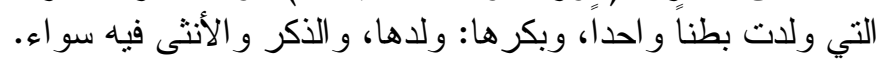

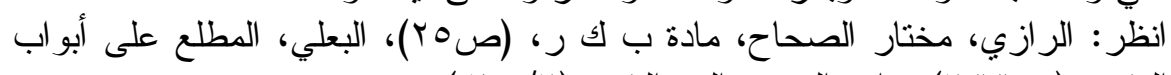

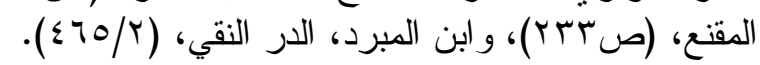

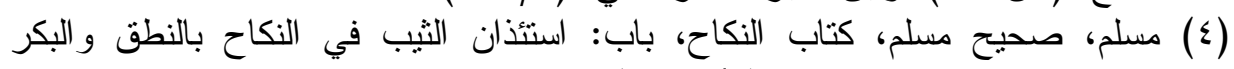

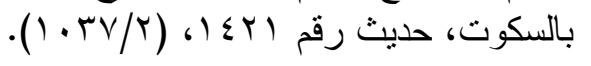




\section{مفهوم الصفة}

فهنا قسَّم المر أة إلى قسمين:

الثيب: وهي التي فارقت زوجها، و البكر : و هي التي لم تنزوج. فتخصيص الأيم بأنها أحق بنفسها يدل على نفيه للبكر ، وتخصيص ولكر البكي البكر بالاستئذان يدل على نفيه للأيم.

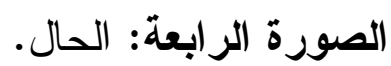

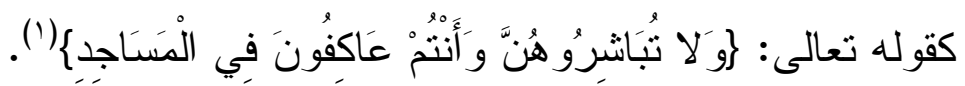
أي: لا تباشرو ا نسائكم حال كونكم معتكفين. الصورة الخامسة: ظرف الزانة الزمان.

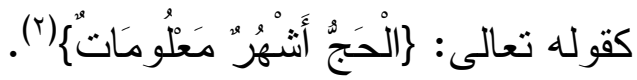
الصورة السادسة: ظرف المكان.

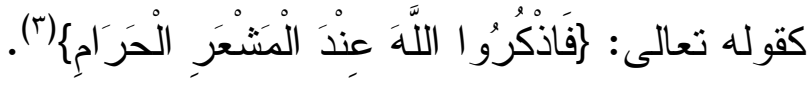
الصورة السابعة: مفهوم العلة. مثل: " إحرمت الخمر لثدتها《. فيدل على أن ما لا شدة فيه لا يحرم (ई).

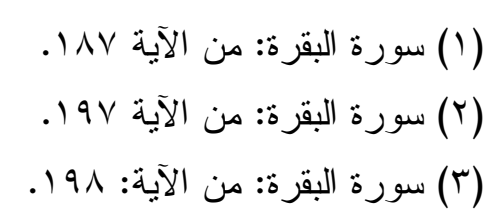

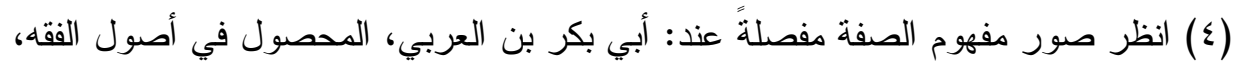

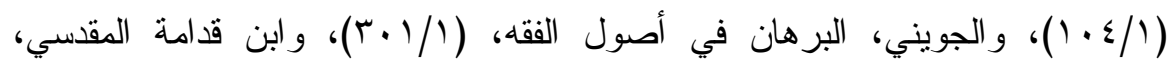

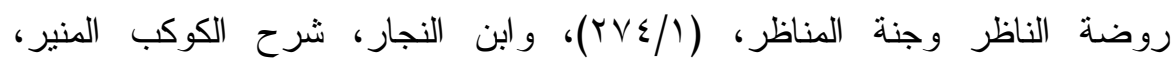

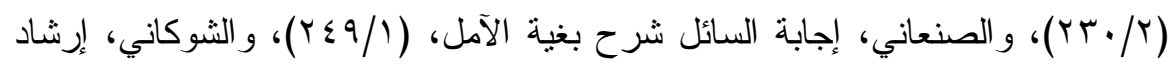

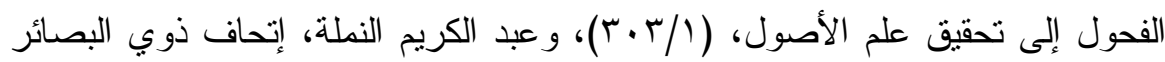

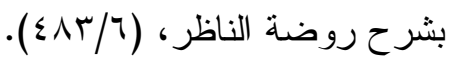




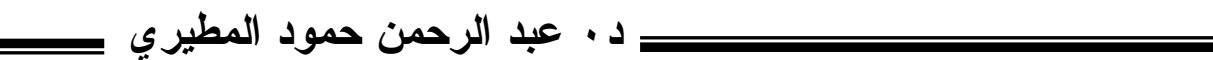

المبحث الثالث

الآثار الفقهية المبنية على الاختلاف

\section{في تطبيق 》مفهوم الصفةة}

لقد كان لاختلاف أنظار الأصوليين إلى مفهوم الصفة، من حيث اعتباره

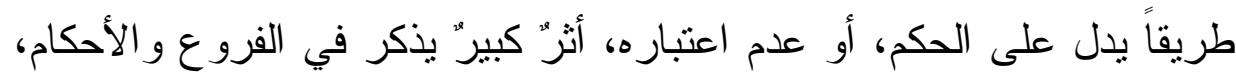

ولقد يقع للمتتبع لأبو اب الفقه على كثير من النماذج التي يطول استقصاؤها.

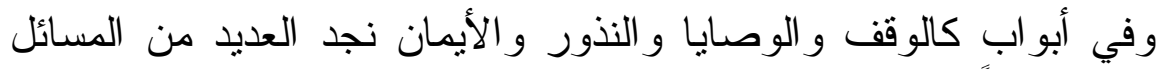
التي جرى الاختلاف فيها بين مختلف المذاهب الفقهية؛ بناءً على اختلافهم في الأخذ بمفهوم الصفة، ما بين الآخذين و الر افضين؛ وبناءً على اختلافهم في تنزيل شروط الأخذ بمفهوم الصفة -ممن بأخذون بمفهوم الصفة- على بعض الصض

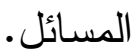

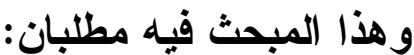

المطلب الأول: في مسائل فقهية قديمة، جرى الاختلاف في حكمها بين الفقهاء، وكان من أسباب ذلك الاختلاف استخلالهم بمفهوم الصفة من عدمه.

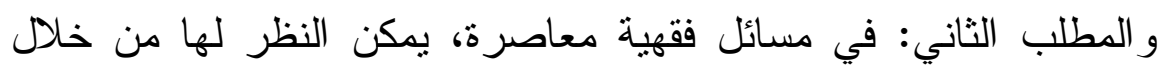
تطبيق مفهوم الصفة، مما يُظهر أهمية هذا الهنحى الأصولي في مسائل

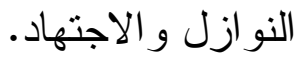




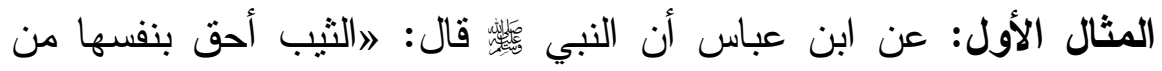

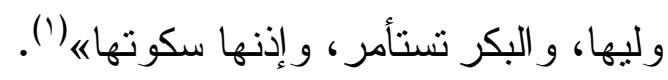

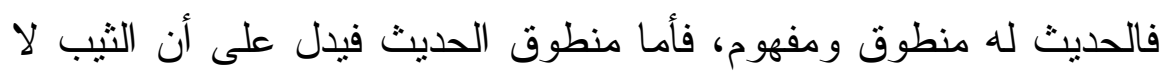

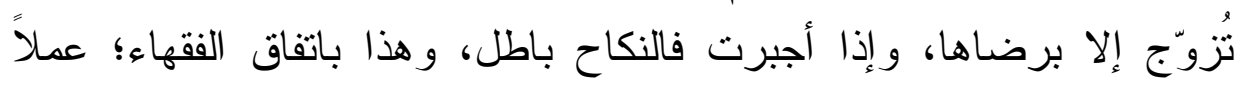

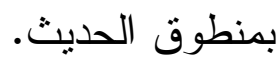

و أما مفهوم الحديث فيدل على أن للأب إجبار ابنته البكر البالغة على

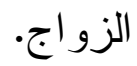

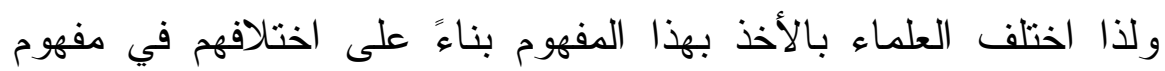

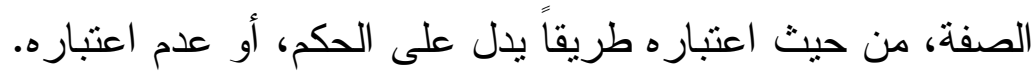

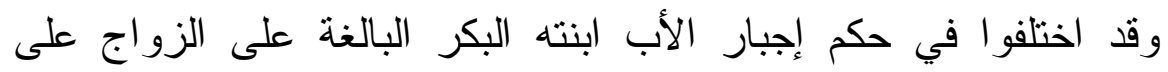

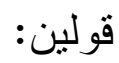

القول الأول: أنه يجوز للأب إجبار ابنته البكر البالغة على الزواج، وبهذا

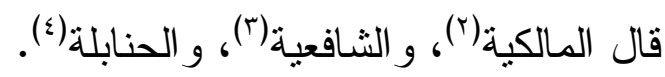

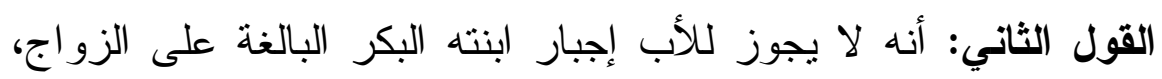

وبهذا قال الحنفية( ).

وسبب اختلافهم يعود لاختلاف نظرهم إلى مفهوم الصفة، من حيث

اعتباره طريقاً يدل على الحكم، أو عدم اعتباره.

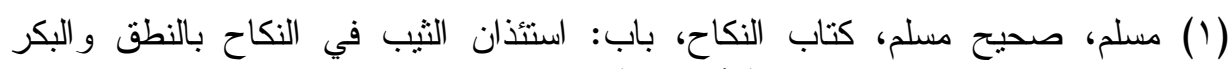

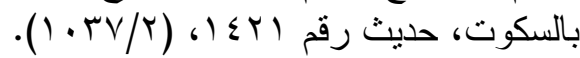

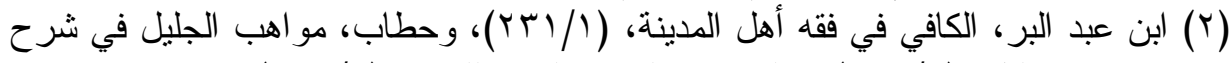

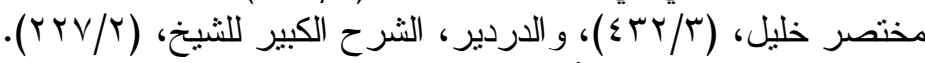

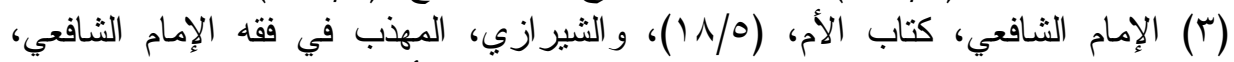

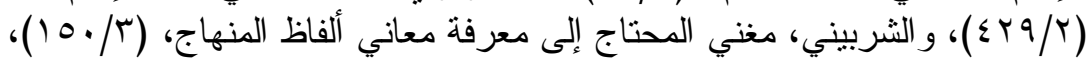

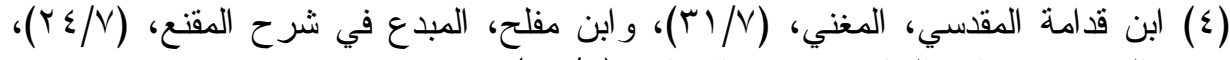

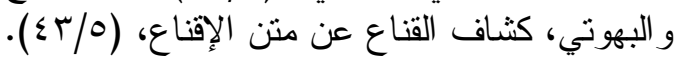

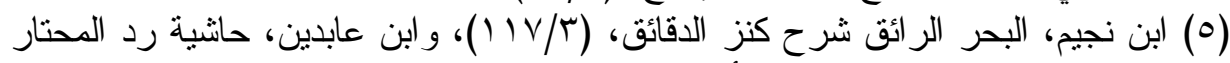

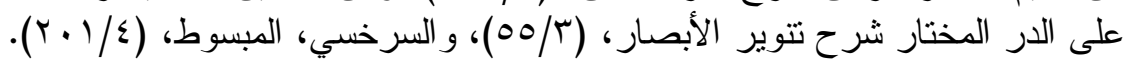




\section{د د إن عبد الرحمن حمود المطيري}

فالحنفية لم يأخذو ا بمفهوم الحديث؛ لأنهم لا يرون بمفهوم الصفة، وأما لرحن

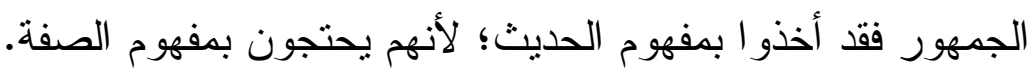

قال الثافعي -رحمه الله-: اويشبه في دلالة سنة رسول اله -صلى الله

عليه وسلم- إذ فرّق بين البكر و الثيب، فجعل الثيب أحقّ بنفسها من وليها،

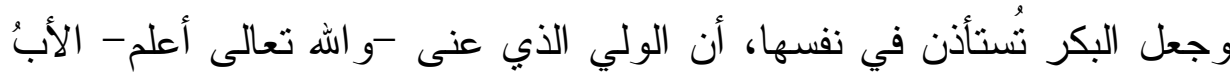

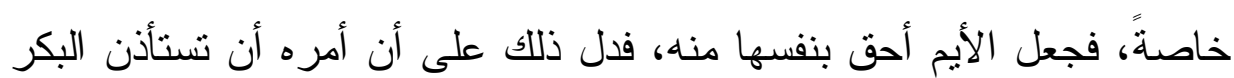

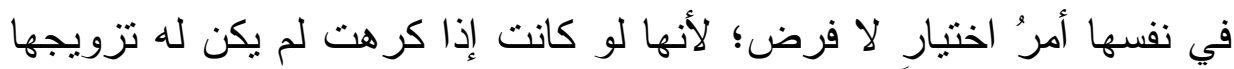

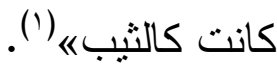

وقال البهوتي: اوللأب تزويج بناته الأبكار ولو بعد البلوغ؛ لحديث ابن

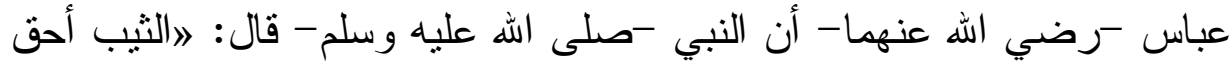
بنفسها من وليها، و البكر تستأمر، و إذنها سكوتهاه، فلما قسم النساء قسمين، و أثبت الحق لأحدهما، دل على نفيه عن الآخر ، وهي البكر، فيكون وليها أحق ونق

$$
\text { منها بهاه (r) }
$$

المثال الثاني: عن ابن عر -رضي الله عنهما-، أن رسول اله -صلى

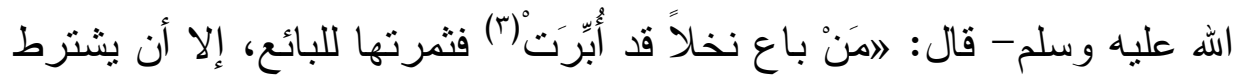
المبتاعه (๕)

$$
\text { (Y) (1) الإمام الثشافعي، كتاب الأم، (1) (1) (1). }
$$

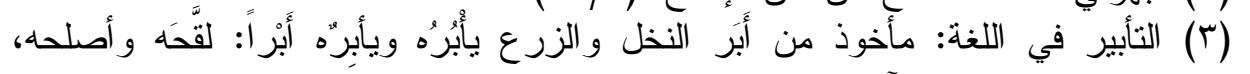

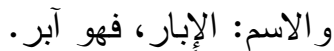

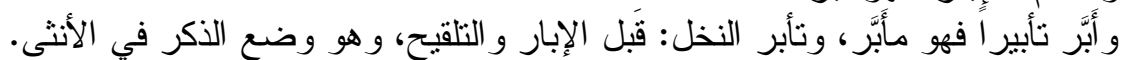

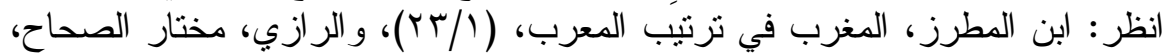

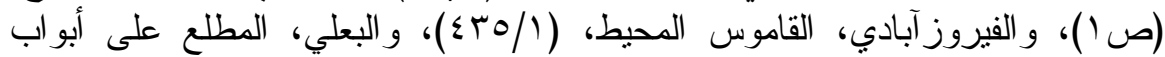

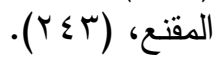

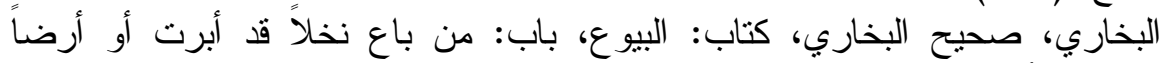

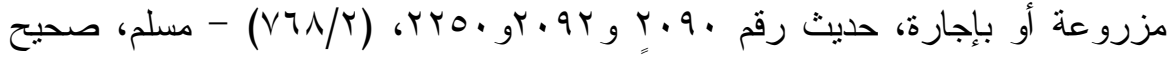

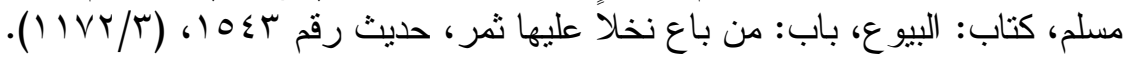




\section{مفهوم الصفة}

فالحديث له منطوق ومفهوم، فأما منطوق الحديث يدل على أن النخل إذا

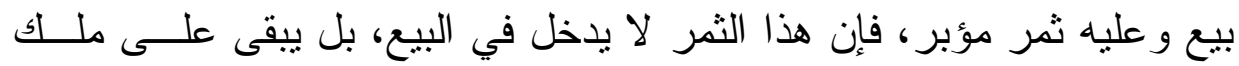
البائع إلا إذا اثترطه المشتري، وهذ هذا باتفاق العلماء عملاً بمنطوق الحديث.

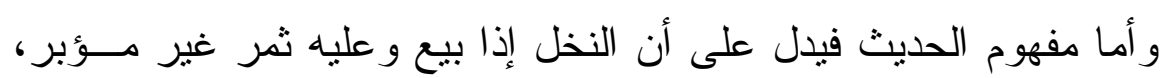
فإن هذا الثمر يدخل في البيع، ويكون ملكاً للمشتري.

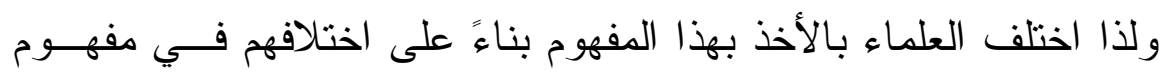

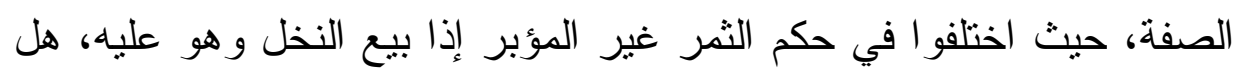

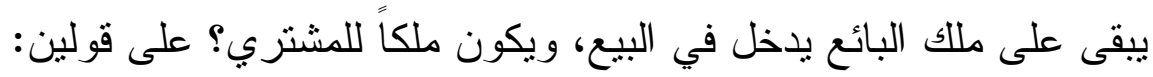

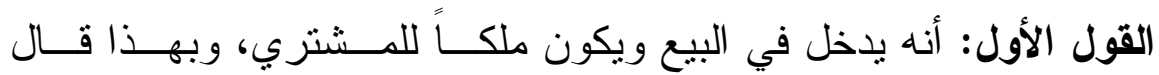

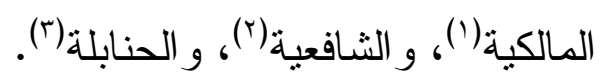

القول الثاني: أنه لا يدخل في البيع وييقى على ملك البائع، وبهــذا قـال الحنفية()

وسبب اختلافهم مبني على اختلاف أنظار هم إلى مفهوم الصفة، من حيث

اعتباره طريقاً يدل على الحكم، أو عدم اعتباره.

(') النفر اوي، الفو اكه الدواني على رسالة ابن أبي زيد القيرواني، (ب/ . (1)، والدسوقي،

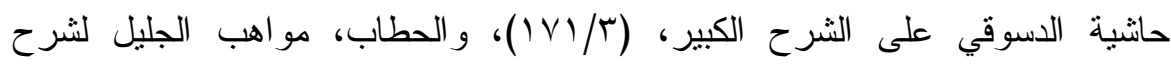

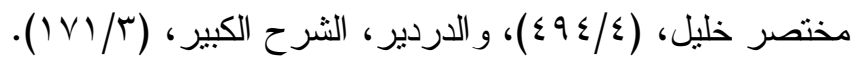

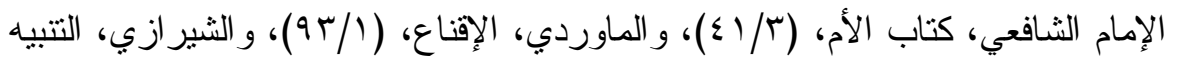

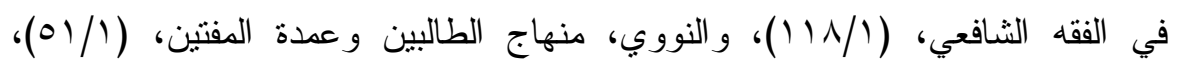

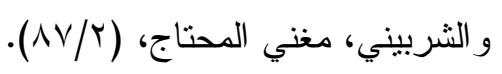

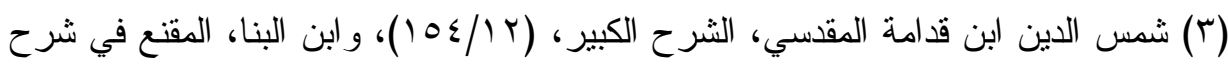

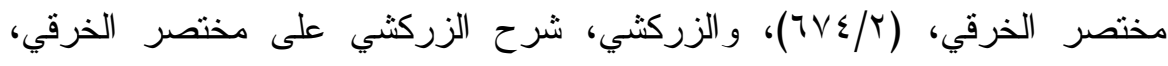

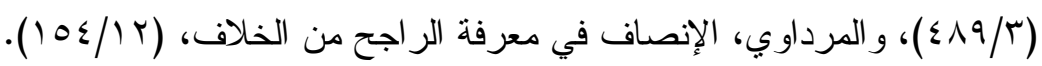

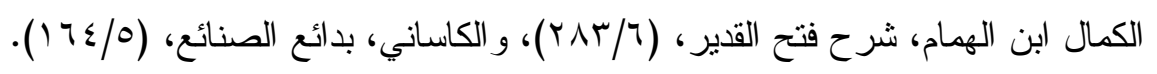


د. • عبد الرحمن حمود المطيري ــ

وقد أوضح ابن قدامة سبب الاختلاف؛ حيث قال: اللخبر الذي عليه مبنى

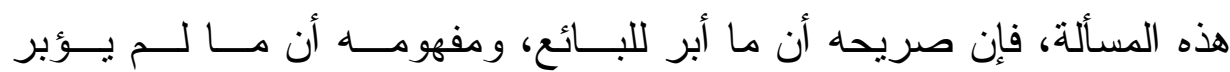
للمشتري《 (')

وقد أخذ الجمهور بمفهوم الحديث؛ لأنهم يأخذون بمفهوم الصفة، من حيث اعتباره طريقاً يدل على الحكم؛ حيث قال الثيرازي: الفدل على أنها إذا لــــ تكن مؤبرة فهي للمبتاعه (؟). و أما الحنفية فلم يأخذو ا بمفهوم الحديث؛ لأنهم لا يرون بمفهوم الصفة من حيث اعتباره طريقاً يدل على الحكم، حيث قال الكمال ابن الههــام الحنفــي: الوحاصله استدلال بمفهوم الصفة، فمن قال به يلزمه، وأهل المذهب ينفــون

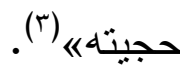
المثال الثالث: عن عمرو بن حزم -رضي الله عنه-، عن النبي -صلى الله عليه وسلم أنه قال: اوفي النفس المؤمنة مائة من الإبله|(ء). فالحديث له منطوق ومفهوم، فأما منطوق الحديث فإن دية النفس المؤمنة مائة من الإبل، و هذا باتفاق العلماء عملاً بمنطوق الحديث. و أما مفهوم الحديث فيدل على أن النفس غير المؤمنة ديتُها لبست مائـــة

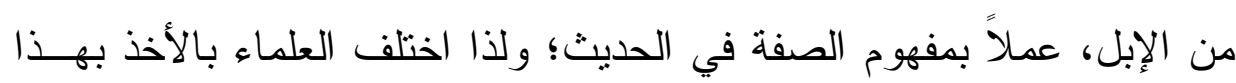
المفهوم بناءً على اختلافهم في مفهوم الصفة. فذهب الجمهور -ممن يُعمل مفهوم الــصفة- إلــى أن غيــر المؤمنـــة بخلافها.

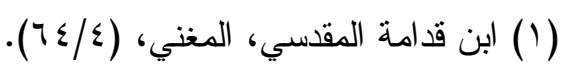

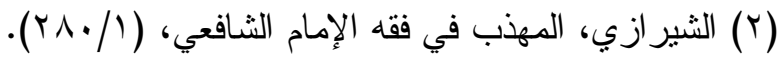$$
\text { (r) (بن الهمام، شرح فتح القدير ، (T/T). }
$$

(ع) الحديث بهذا اللفظ عند البيهقي: سنن البيهقي الكبرى، كتاب: جُمَّاعُ أَبْوَابِ الديّاتِاتِ فِيمًا

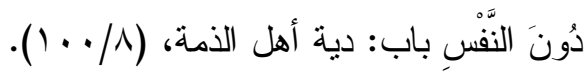




\section{=}

ثم ذهب المالكية(1) و الحنابلة(؟) إلى أن دية أهل الذمة على النصف مــن

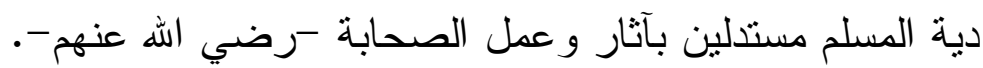

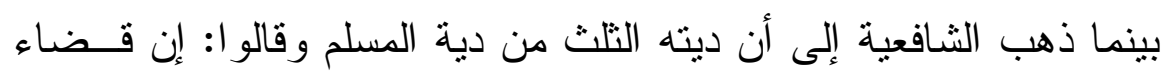

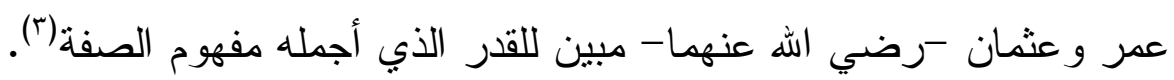

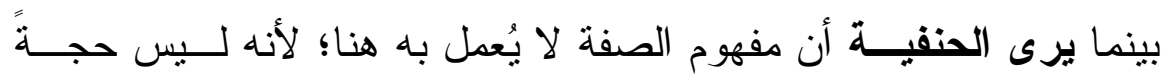

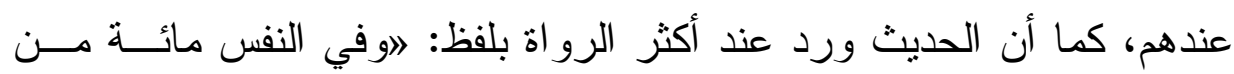

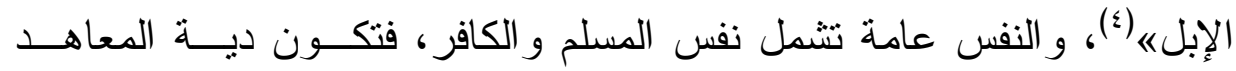

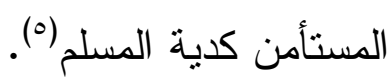

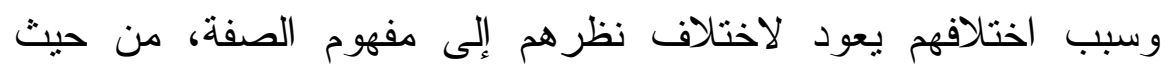
اعتباره طريقاً يدل على الحكم، أو عدم اعتباره. المثال الرابع: مفهوم الصفة في ألفاظ الو اقف: أفي اعثاره

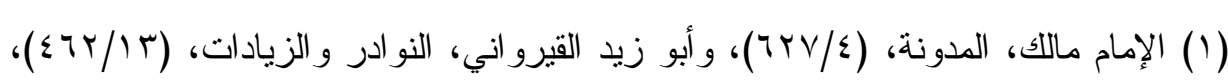

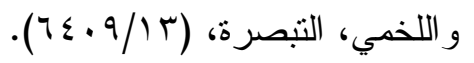

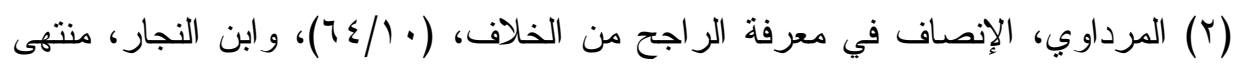

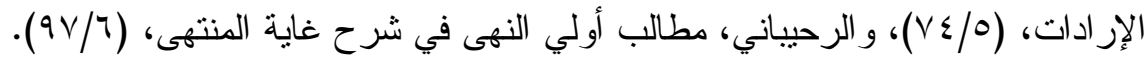

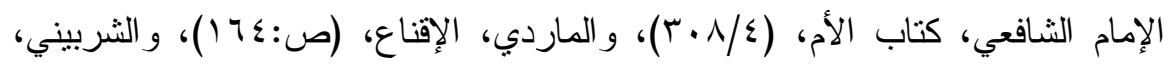

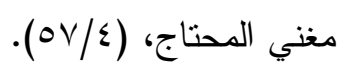

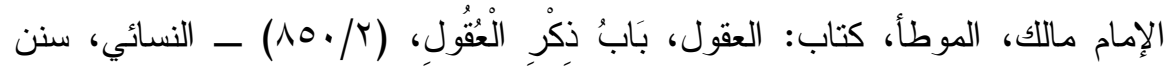

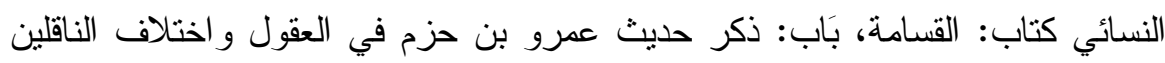

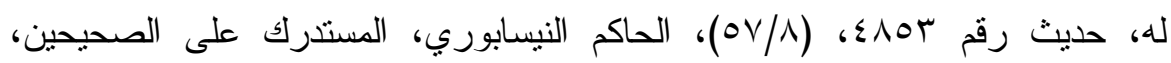

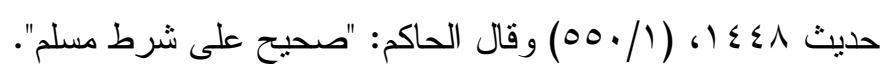

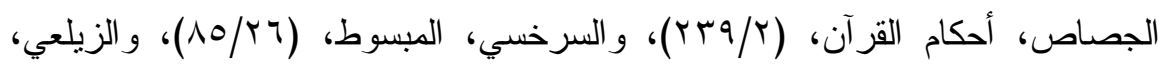

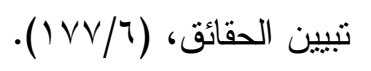




\section{د. • عبد الرحمن حمود المطيري}

من القو اعد المشهورة قاعدة الشرط الو اقف كنص الـشـارعه، و الفقهــاء متفقون على الأخذ بها في الجملة('(r)، لكنهم اختلفو ا في مدلولها ومداها؛ بناءً على خلافهم في الأخذ بمفهوم الصفة. فقال الحنفية: قولهم: الشرط الواقف كنص الـشـارعه أي: فــي الفهـــ و الدلالة ووجوب العمل به، قال ابن عابدين: 》أما المفهوم عندنا فغير معتبــر في النصوص و المر اد به مفهوم المخالفة المسمى دليل الخطاب، وهو أقـسام مفهوم الصفة، و الثرط، و الغاية، و العدد، و اللقب .... وفي البيــري: نحــن لا

(1) الحصفكي، الدر المختار على تتوير الأبصار ، (ع/rr؟)، و الطحاوي، حاثشية الطحاوي

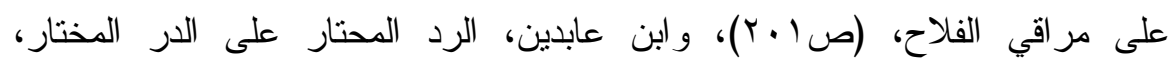

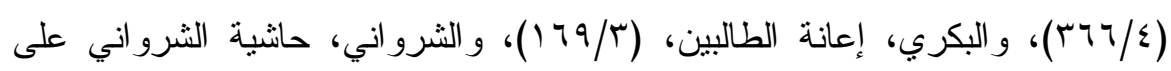

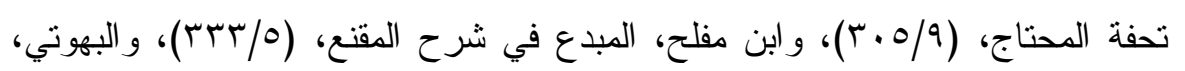

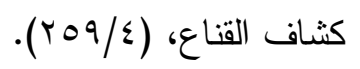

(Y) المر اد بكون شروط الو اقف كنصوص الثار ع في الفهم و الدلالة، وتقييد مطلقها بمقيدها،

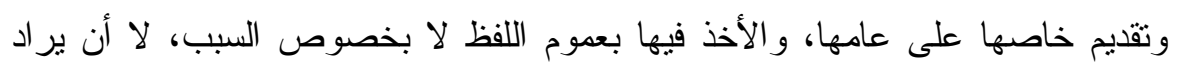

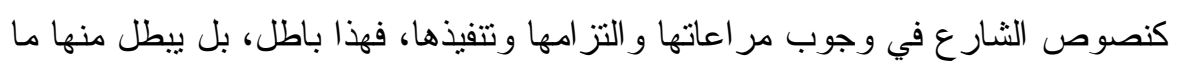

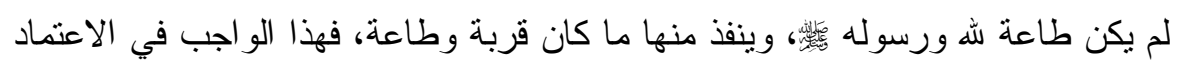

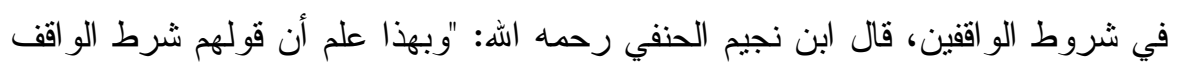

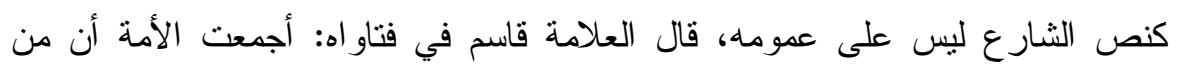

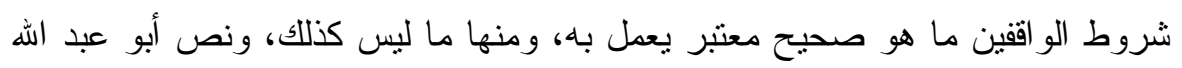

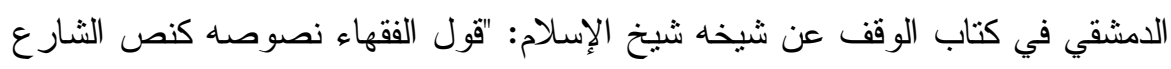
يعني في الفهر والدلالة، لا في وجوب العمل، مع أن التحقيق أن لفظه ولفظ الموصي

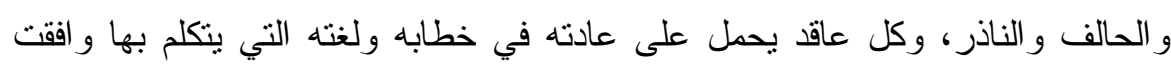

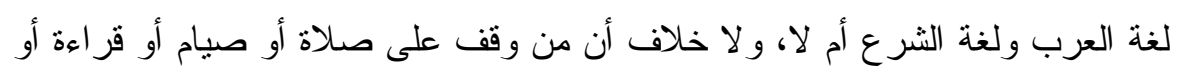

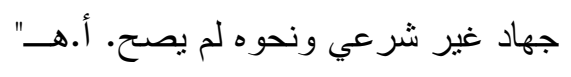

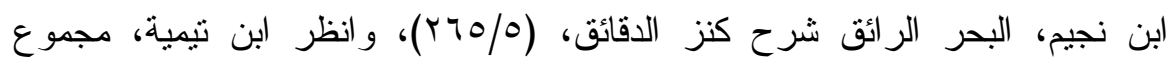

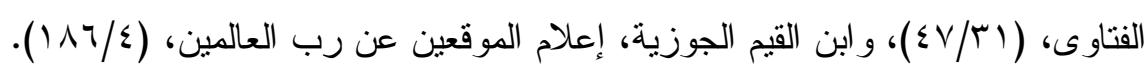




\section{مفهوم الصفة}

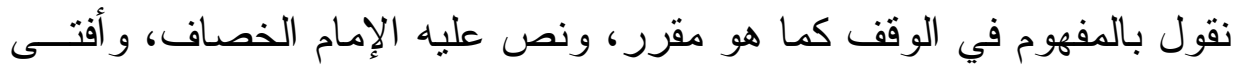

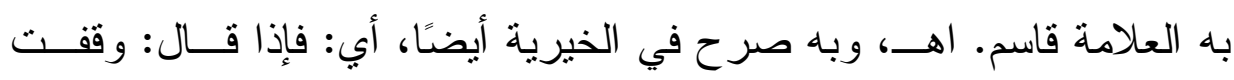

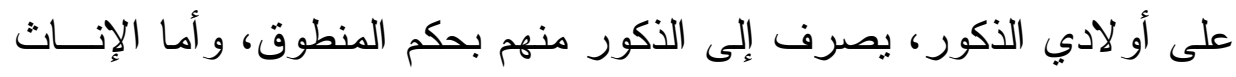

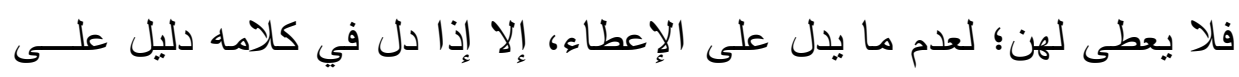

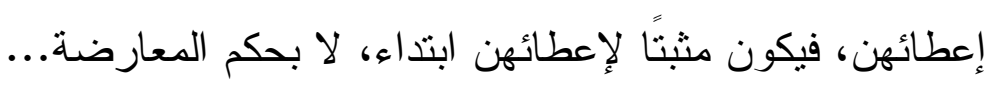

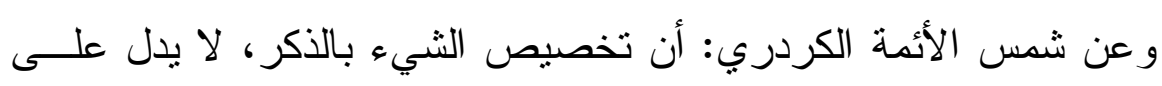

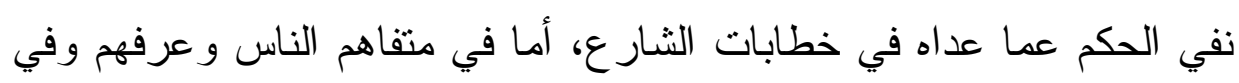

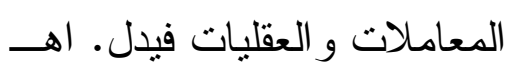

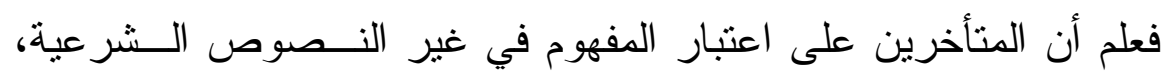

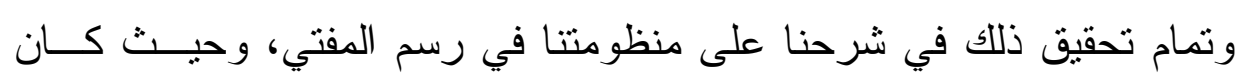

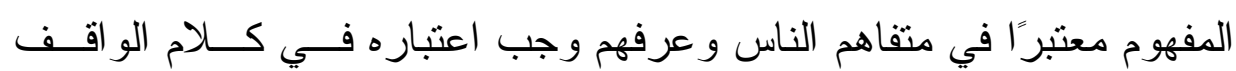

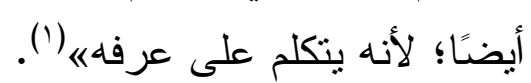

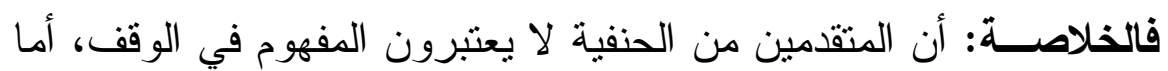

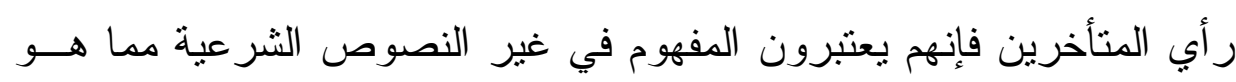
في متفاهم الناس وعرفهم وفي المعاملات و العقليات. وقد جرت و واقعة بُني الحكم فيها على هذا الخلاف عند الحنفية، فقد ذكر النهات

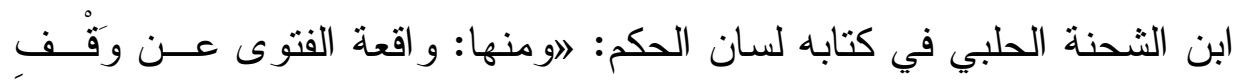

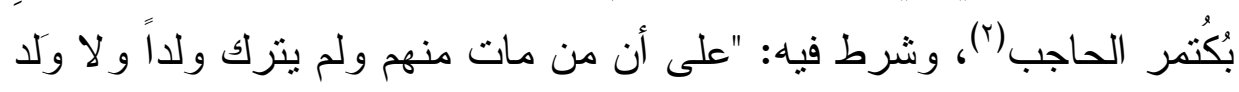

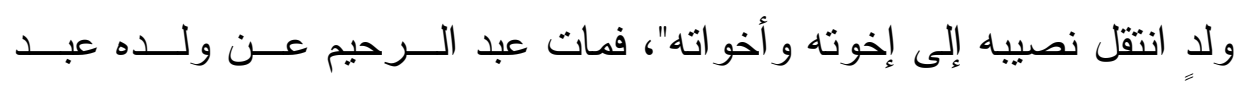

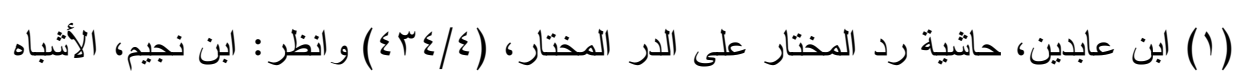

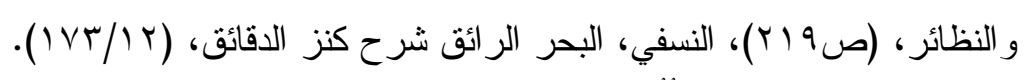

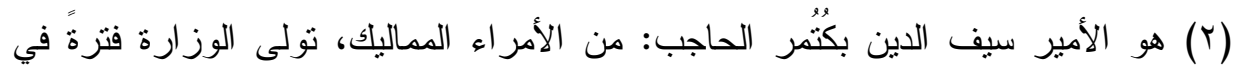

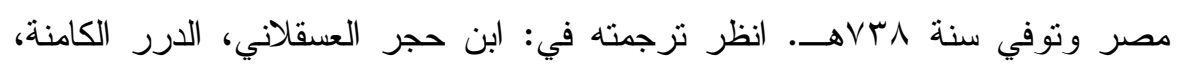

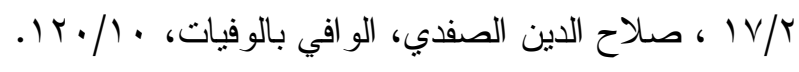

$$
\text { -1.人- }
$$




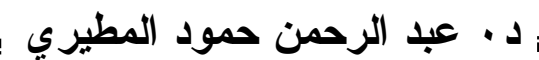

الرحمن، فأجاب بعض المفتين باستحقاق عبد الرحمن نــصيب أبيـــه عمـلاً بمفهوم الصفة.

و أجاب العلامة الثيخ شرف الدين قاسم بأن هذا باطل نقلاً و عقلاً.

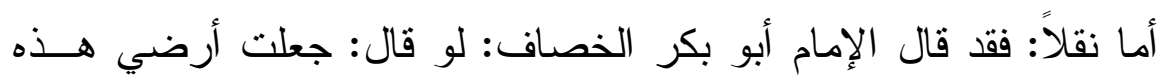

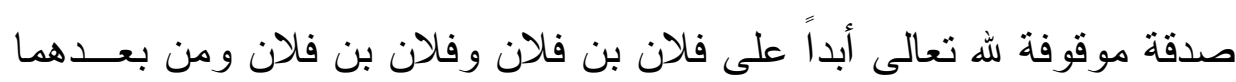

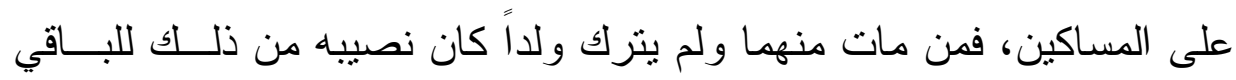

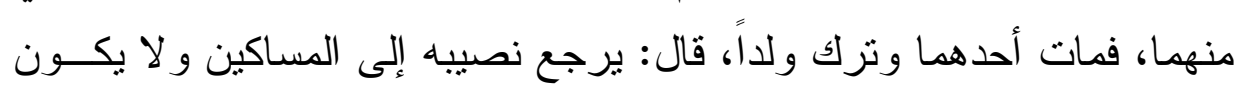
ذلك للباقي منهما؛ من قبل أن الو اقف إنما اشترط أن يرجع نصيب الذي يموت منهما إلى الباقي إذا لم يترك الميت وارثاً وهذا قد ترك و ارثاً وهو ولده. قلت فلم لا تجعل نصيب الميت منهما لولده؟! قال: من قبل أن الو اقف لم يجعل ذللك لولا الميت، إنما قال: مــن مــات

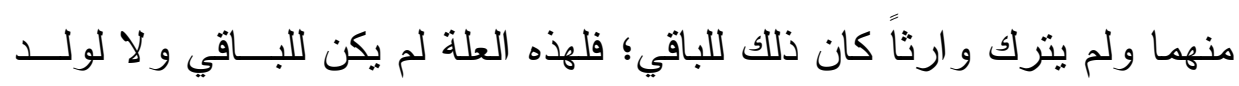
الميت من ذلك شيء. و أمـا عقلاً: فلأن المفهوم ليس من المدلول اللغوي و إنما يكون باعتبــار التفاوت النفسي إليه، و هذا لا يعلم من الواقف فلا يصح العمل بهی('). بينما ذهب الجمهور من المالكية و الثافعية و الحنابلة إلى الاعتداد بمفهوم الصفة في شرط الو اقف، فيوجبون العمل به، وهو الوصف الوارد في شرطه الو اقف، فيُعملون مفهوم الصفة في شرطه.

فلو اشترط تخصيصَ لأهل مذهب من المذاهب الأربعة، أو بتدريس فئة في مدرسته أو بتخصيص إمام في مسجده، أو تخصيص ناظر ، اتبع شرطه(ب).

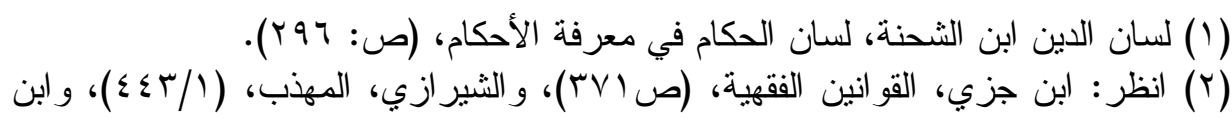

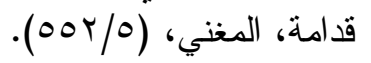




\section{=}

المطلب الثاني: مسائل فقهية معاصرة

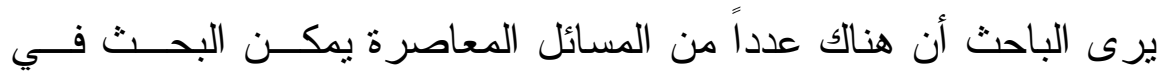

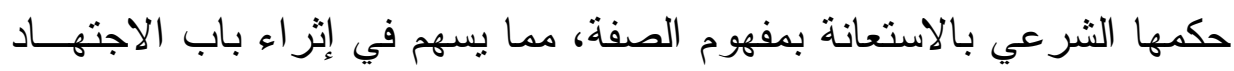

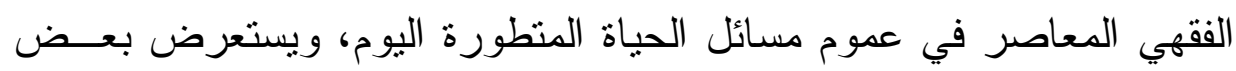

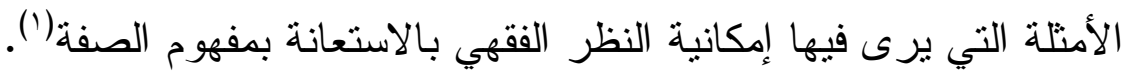

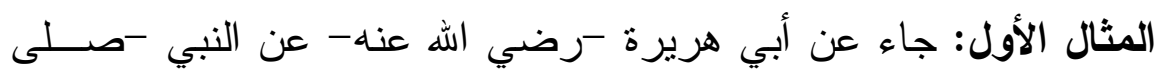

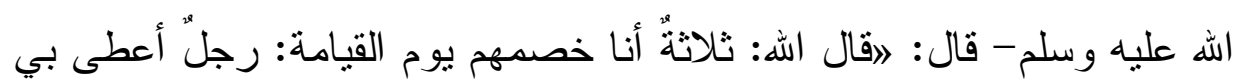

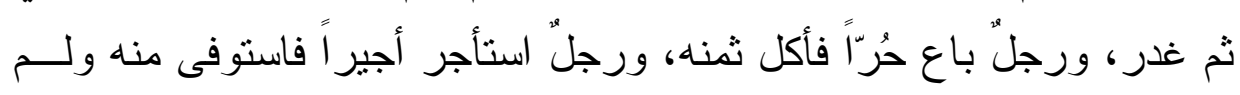
يعطه أجرها (r).

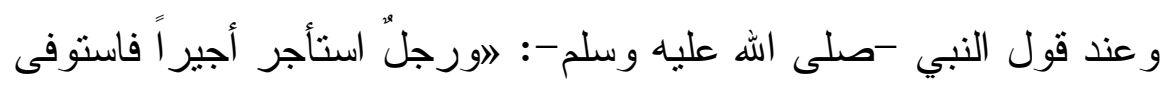

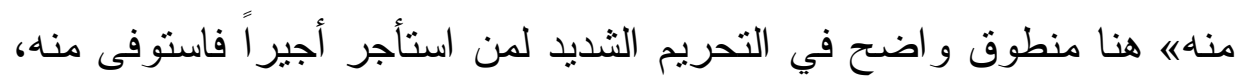
العمل، ثم قصرّ معه في أجرته المتفق عليها.

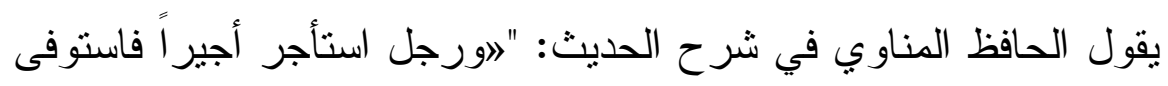

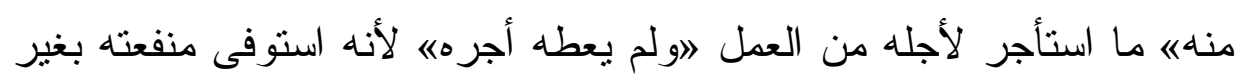
عوض، و استخدمه بغير أجرة، فكأنه استعبده"("). و الوصف الو ارد بالحديث 》فاستوفى منهاه يمكن إعمال مفهوم الصفة فيه

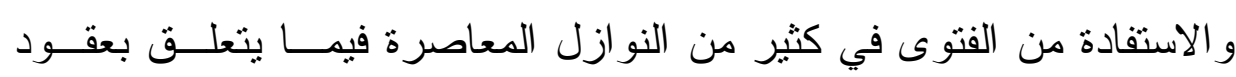
التشغيل وعقود التأجير وما شابهها.

(1) ليس المقصود من البحث بيان الحكم الشرعي لهذه النوازل المعاصرة، و إنما المقصود

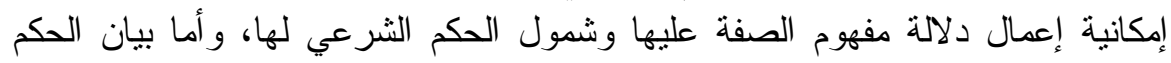

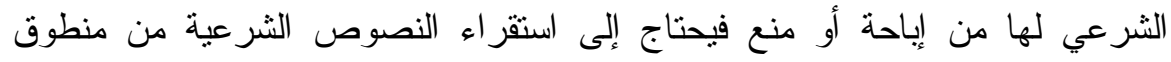

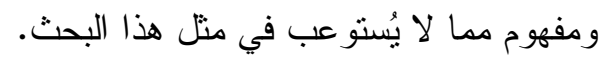

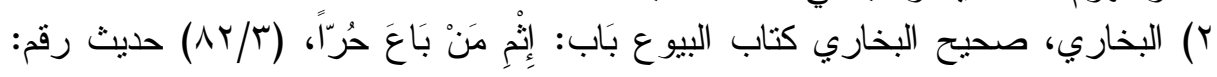




\section{د د · عبد الرحمن حمود المطيري}

حيث يكون هناك خلل" في التنفيذ، أو في تخلّف بعض شروط العقد، فهنا

$$
\text { لا يتم استيفاء ما تم الاتفاق عليه في العقد. }
$$

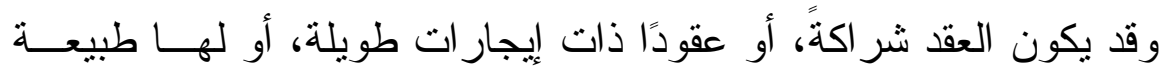

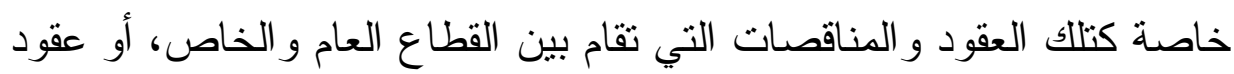

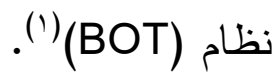

مصطلح (B.O.T). اختصار لثلاث كلمات باللغة الإنجليزية هي: البناء Build، النتغيل

Transfer Operate

وعرف نصار مصطلح مشروعات (BOT) بأنه: المشروع الذي تعهد الحكومة ببنائه إلى إحدى الثركات، وذللك لإنثاء مرفق عام ونتغيله لحسابها مدة من الزمن، ثم نقل ملكيته

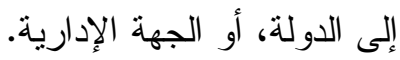

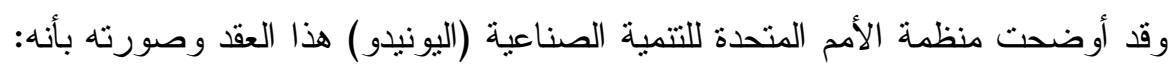
اتفاق تعاقدي ينولى بمقتضاه أحد أثنخاص القطاع الخاص إنثاء أحد المر افق الأساسية

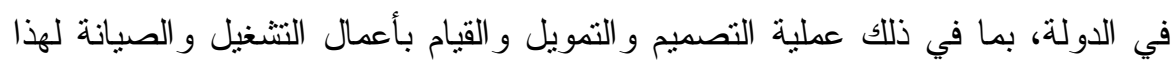

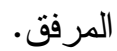

وتقوم هذه الثخصية الخاصة بإدارة وتثغيل المرفق خلال فترة زمنية محددة، بسمح لها

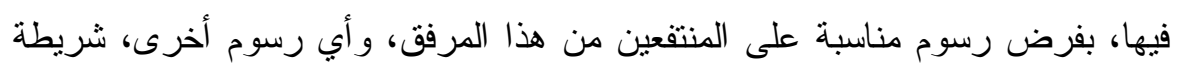
ألاً تزيد على السعر المتفق عليه سلفًا.

و القصد من ذلك أن تسترجع الثركة الأمو ال التي استثرنها، و المصاريف التي أنفقتها وتتفقها في النتغيل و الصيانة، بالإضافة إلى نحقيق العائد المناسب لإنتثمار ها.

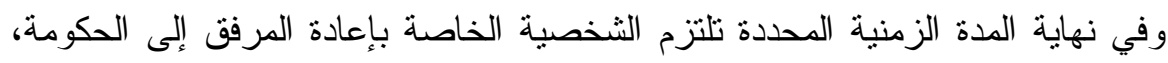

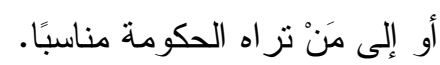

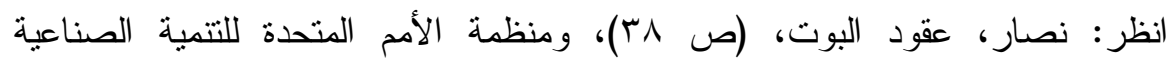

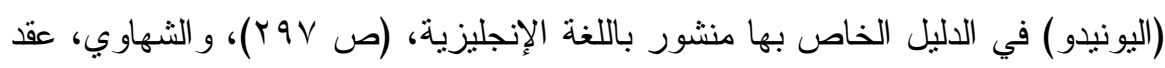

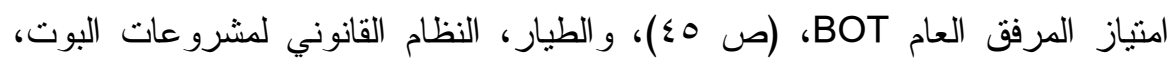

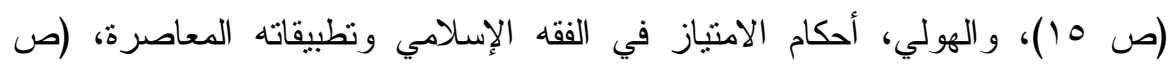

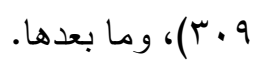




\section{=

$$
\text { يُعطى أبداً }
$$

ثم سيبرز سؤال فقهي آخر : هل يُعطى بقدر الجهد الذي تمَّ ناقــصاً أو لا

و هذه مسائل معاصرة يمكن الاستتباط فيها من خلال النظر فـــ مفهـوم

$$
\text { الصفة في أصل النص الثرعي وتفريعاتها. }
$$

المثال الثاني: عن أبي هريرة - رضي الله عنه- قال: إنهى رسولُ الله

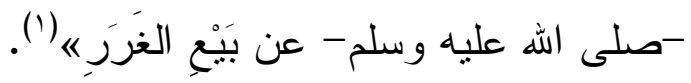

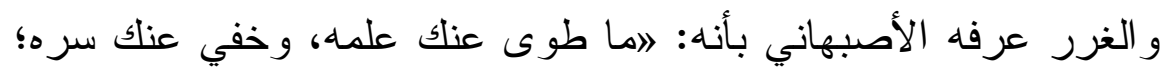

$$
\text { من قولهم: طويت الثوب على غرةها (r). }
$$

وفسره القاضي أبو يعلى وجماعة: لها تردد بين أمرين لــيس أحسدهما

$$
\text { أظهر } 1)^{(r)}
$$

و النهي عن الغرر أحد قو اعد الثريعة الإسلامية في بـاب المعـاملات

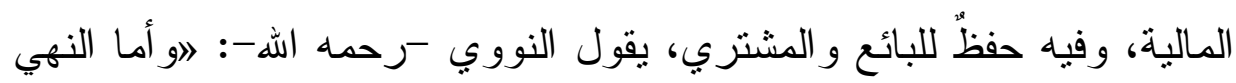

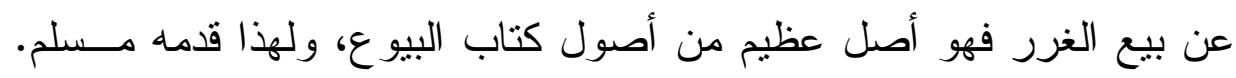

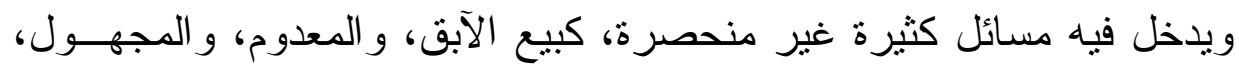

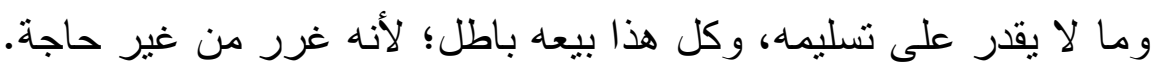

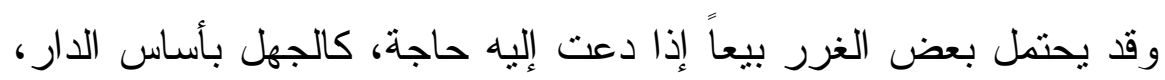

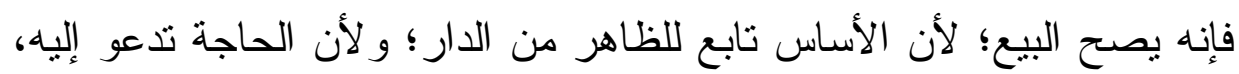

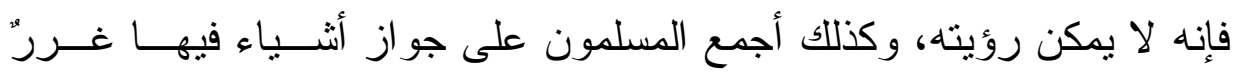

(1) مسلم، صحيح مسلم، كتاب: البيوع، باب: بطلان بيع الحصاة والبيع الذي فيه غرر،

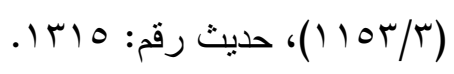

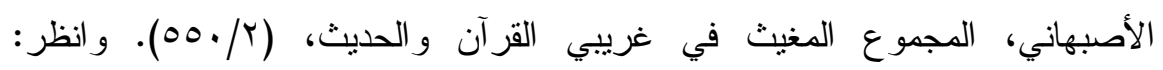

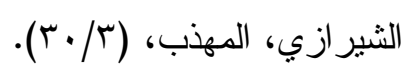

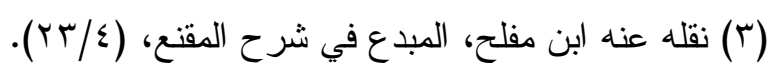




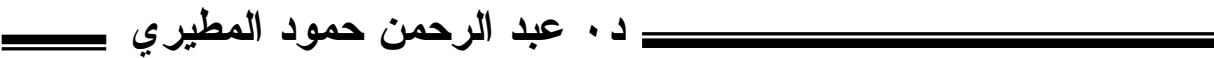
حقير"، منها: أنهم أجمعو ا على صحة بيع الجبة المحشوة و إن لم ير حـشوها، ولو بيع حشو ها بانفر اده لم يجز •

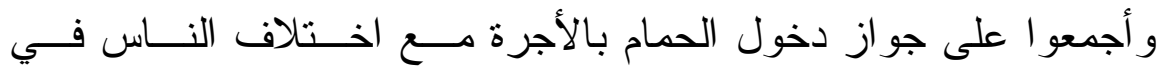
استعمالهم الماء، وفي قدر مكثهم" ('). بل لا يكاد يخلو عقد بيع من الغرر (؟)؛ ولهذا نقل عدد من العلماء الإجماع على أن بسير الغرر مغتفر (r). كما بيّن العلماء أن ضابط الغرر غير المؤثر: هو اليسير، أو الذي تدعو

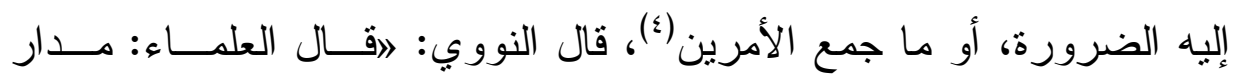
البطلان بسبب الغرر و الصحة مع وجوده على ما ذكرناه، وهو أنه إن دعــت حاجة إلى ارتكاب الغرر و لا يمكن الاحتر از عنه إلا بمشقة وكان الغرر حقيراً جاز البيع، و إلا فلاه" (०). فالحديث النبوي نهى عن العقد الموصوف بالغرر و الجهالة، فهنـــا فـي النص النبوي مفهوم صفة؛ إذ مؤداها: أن كل عقد لا غرر فيه فهو غير منهي عنه، وبما أن العلماء مجمعون على أنه لا يكاد عقد يخلو من غرر، فلا بد من تقييد الغرر المنهي عنه بضو ابط أهمها: الكثرة، و عدم الحاجة لــه، و القــدرة على اجتتابه و التحرّز منه. و هنا يمكن معالجة الكثير من العقود المالية المعاصرة المستحدثة - و التي لا نصَّ فيها- عبر النظر فيها من مفهوم الصفة: هل هي ضمن الغرر المنهي عنه أو من الغرر المتسامح فيه؟

$$
\begin{aligned}
& \text { (1) النووي، شرح النووي على صحيح مسلم، ( ( (107/(1))، مختصرًا. }
\end{aligned}
$$

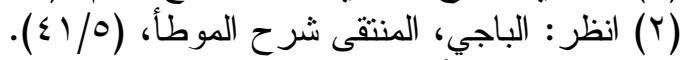

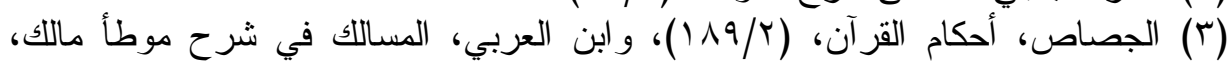

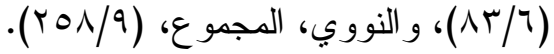

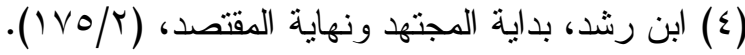

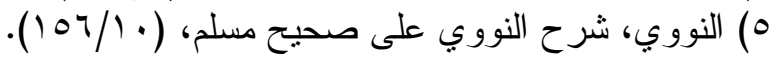




\section{=}

فمثُلاً: التأجير المنتهي بالتمليك|('): عقد معاصر فيه جانب من الغرر في

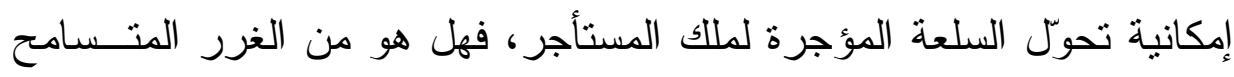

بـد ومثثلا: الكفالات المقدمة على الأجهزة الكهربائية و الإلكترونية: هل هـي هي

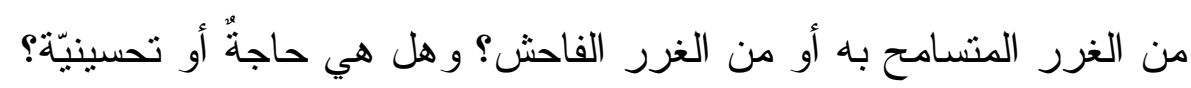

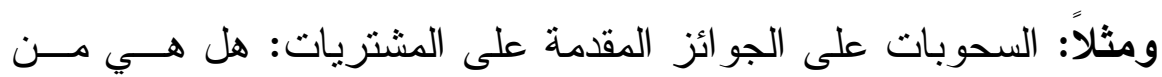

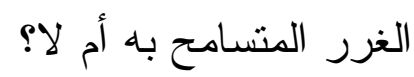

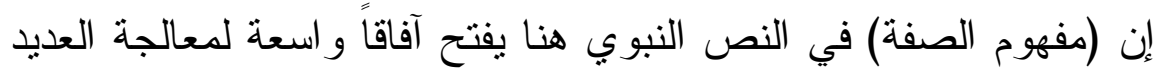
من العقود المعاصرة المستحدثة.

المثال الثالث: عن أبي هريرة -رضي الله عنه- قال: قال رسول اله -

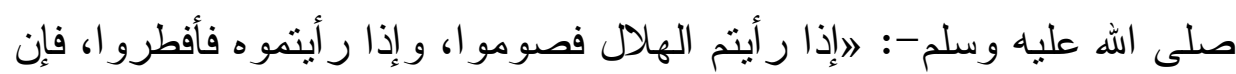

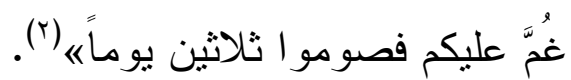

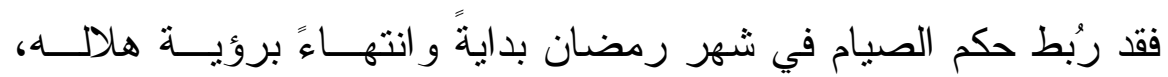

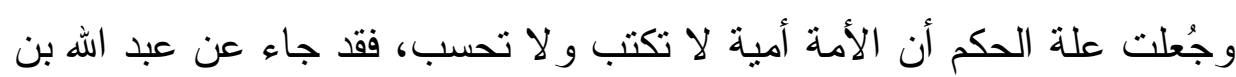

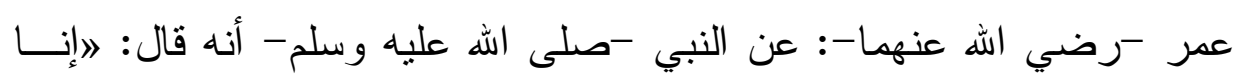

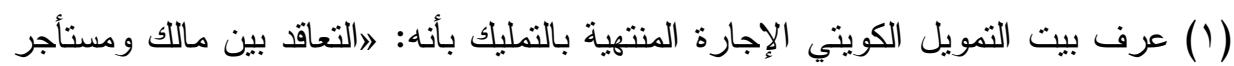

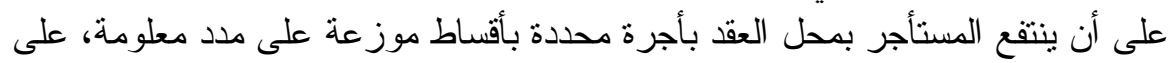

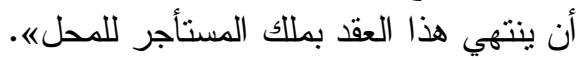

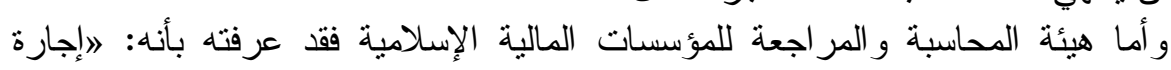

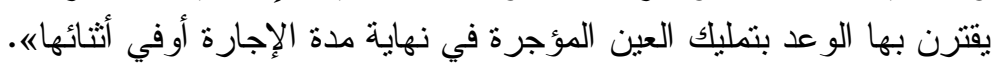

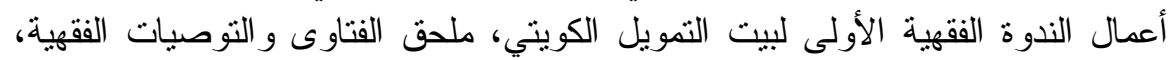

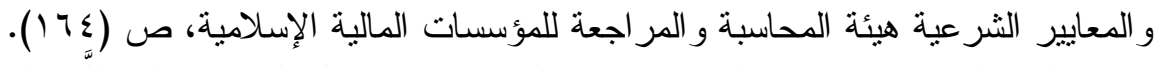

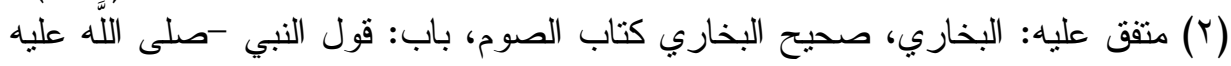

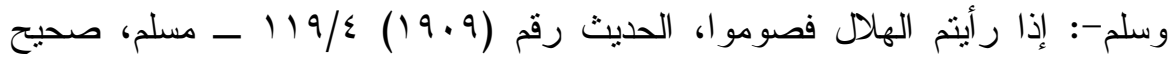

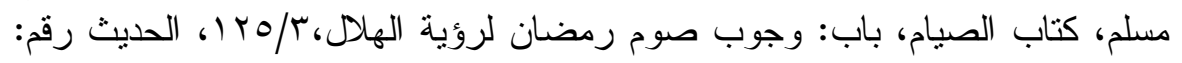




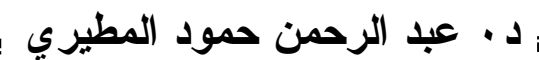

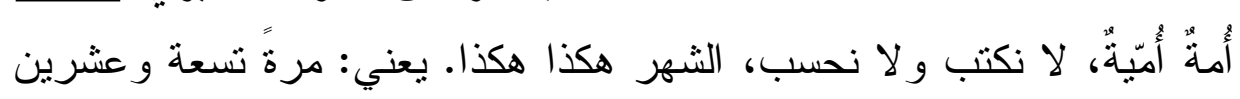

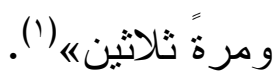

و الصفة هنا في الحديث: 》أمة أميةه، فمنطوق الحــديث: إننا أميــون لا له

نكتب و لا نحسب فاعتمادنا في معرفة دخــول الــشهر وخروجـــه بالرؤيـــة البصرية.

ومفهوم الحديث: أن الأمة إذا تحولت لأمة متعلمة فالحكم قد يختلف عند من يأخذ بمفهوم الصفة، ومثله أيضاً: 》لا نكتب ولا نحسبش، فهي أيضاً في حكم الصفة، لها منطوق ومفهوم، فإذا أصبحنا نكتب ونحسب، فــإن مفهــوم الصفة ينبغي أن يكون حاضر اً هنا في النظر الفقهي لمن يعتبر به. يقول الحافظ ابن حجر في فتح الباري: "»لا نكتب و لا نحسب هوب و المــر اد أهل الإسلام الذين بحضرته عند تللك المقالة، وهو محمول على أكثتـرهم ... لأن الكتابة كانت فيهم قليلة نادرة. و المر اد بالحساب هنا حساب النجوم وتسبير ها، ولم يكونو ا يعرفون مــن ذلك أيضاً إلا النزر اليسير ، فعلَّق الحكم بالصوم وغيره بالرؤية؛ لرفع الحرج عنهم في معاناة حساب التسيير"(r). وكلام الحافظ ابن حجر و اضح في أن ربط الحكم بالرؤية البصرية سببه عدم المعرفة بالحساب وقلة انتشار العلوم (r).

(1) البخاري، صحيح البخاري كتاب: الصوم، باب: قول النبي صلى الله عليه وسلم: (لا

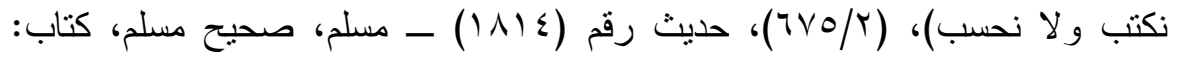

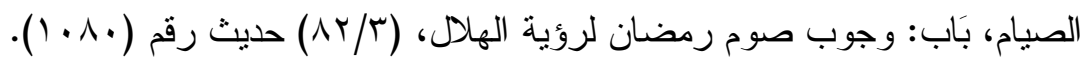

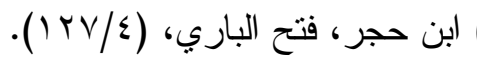

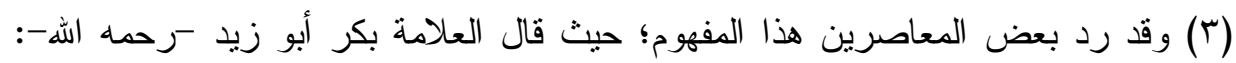

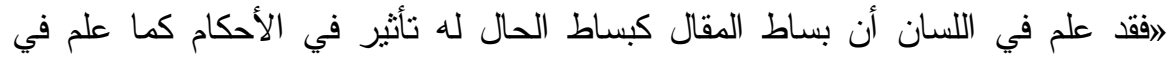

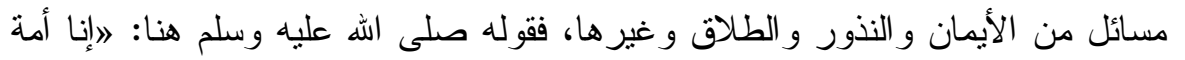

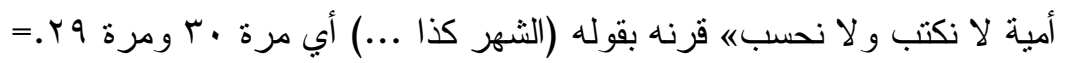




\section{مفهوم الصفة - م}

ومن أسباب رفض الفقهاء لموضوع الحساب و الفلك وحساب النجوم أنه

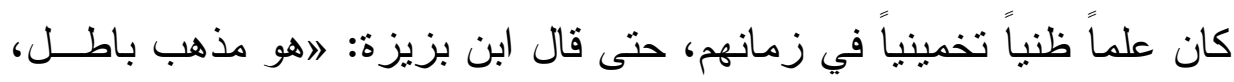

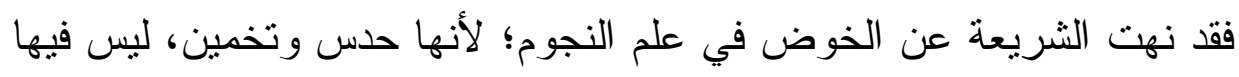

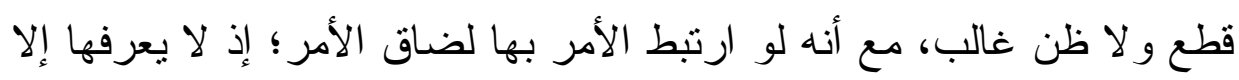
القليله (')

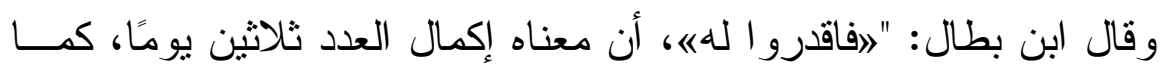

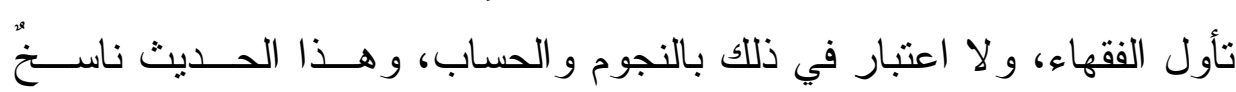

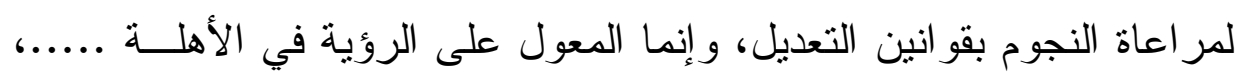

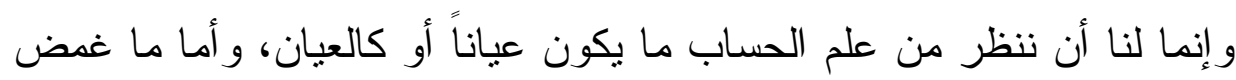

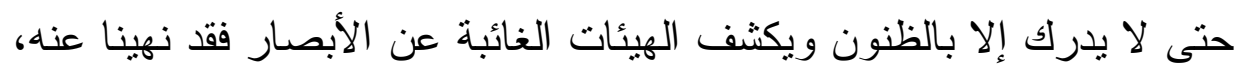
وعن تكلفه" (r).

وقال ابن تيمية -رحمه الله- في معرض احتجاجه لعدم جــواز اعتمــاد

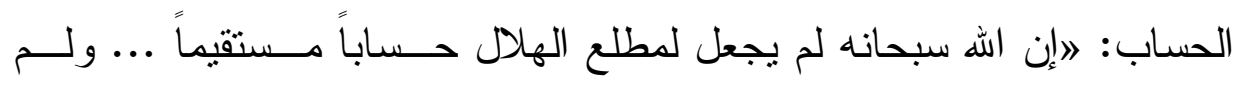
يضبطو اسيره إلا بالتعديل الذي يتفق الحساب على أنه غير مطرد، و إنما هو

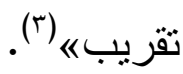

=لفهو محض خبر من النبي صلى الله عليه وسلم لأمته: أنها لا تحتاج في أمر الهال

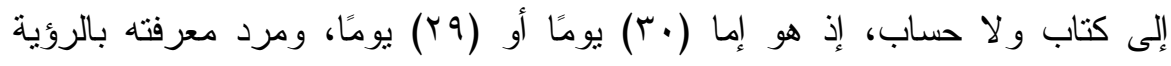

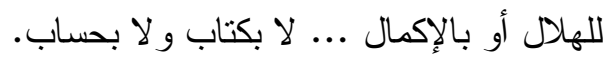

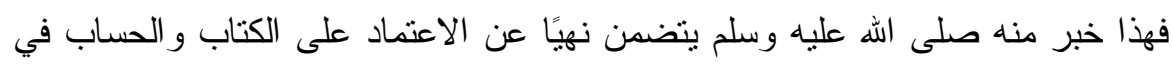

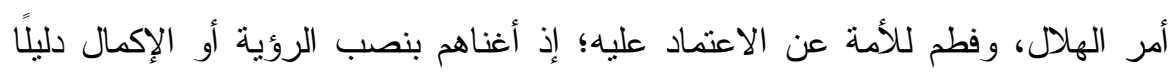

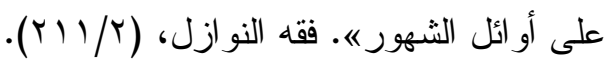

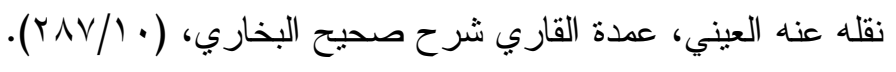

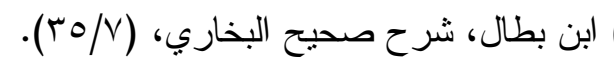

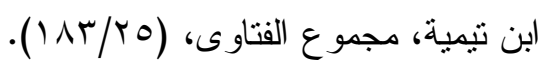




\section{د. • عبد الرحمن حمود المطيري}

و الأمر اليوم هل يحتاج لإعادة نظر بناءً على التقدم الهائل في علم الفلك و الرصد و المر اقبة، وهل يمكن أن نصل لمرحلة ينم فيها ضبط دخول الهلال

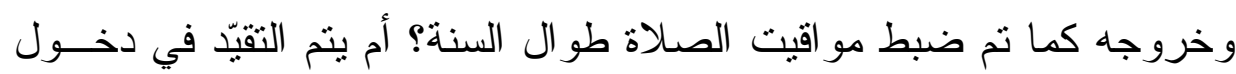

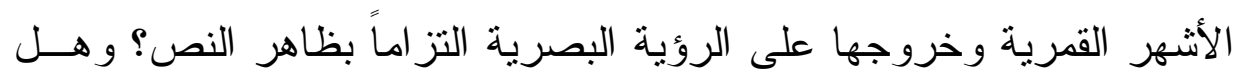
يمكن هنا إعمال مفهوم الصفة أو ليس لله اعتبار؟ كل هذا يحتاج للنظر الفقهي الأصولي في مثن هذه النو ازل.

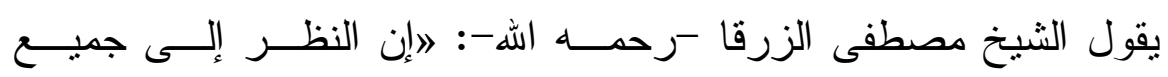

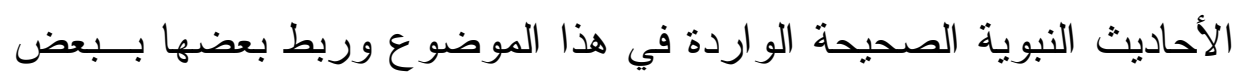
وكلها واردة في الصوم و الإفطار يبرز العلة السببية في أمر الرسول -صلى ولى لادئ

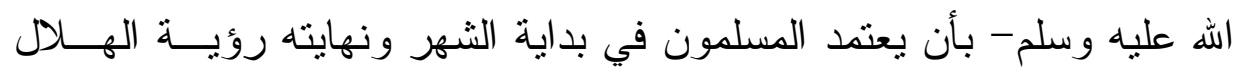

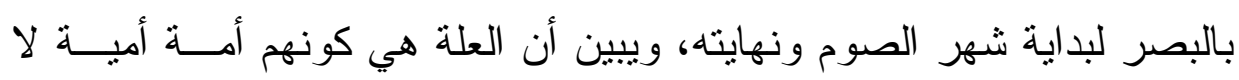
تكتب و لا تحسب، أي: ليس لايهم علم وحساب يعرفون متى يبدأ الثهر ومتى ونه ينتهي، ما دام الثهر القمري يكون تارة تسعة وعشرين يومًا وتارة ثثلاثين.

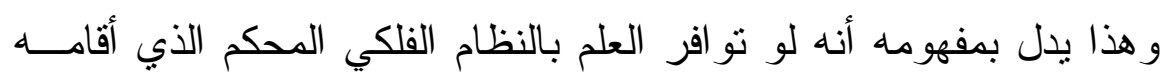
الله تعالى بصورة لا تختلف و لا تتخلف، و أصبح هذا العلم يوصلنا إلى معرفة بولى يقينية بمو اعيد ميلاد الهلال في كل شهر ، وفي أي وقت تمكن رؤيته بــالعين الباصرة السليمة إذا انتفت العوارض الجوية التي قد تحجب الرؤية، فحينئذ لا لهائل يوجد مانع شرعي من اعتماد هذا الحساب و الخروج بالمسلمين مــن مــشكلة إثبات الهلال، ومن الفوضى التي أصبحت مخجلة بل مذهلة، حيث يبلغ فرق

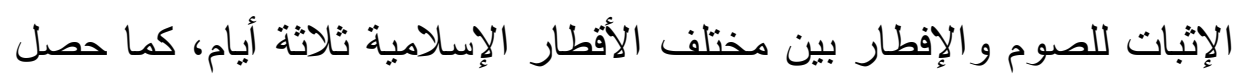
في هذا العام، وفي معظم الأعو ام الماضيةه (')(؟).

(1) الثيخ مصطفى الزرقا رحمه الله - في بحثة المقدم و المنشور في مجلة مجمع الفقه

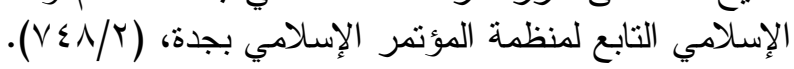

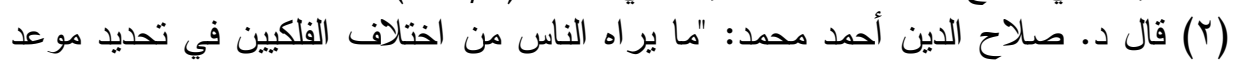

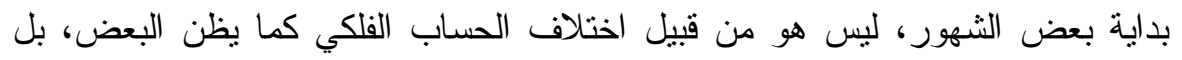

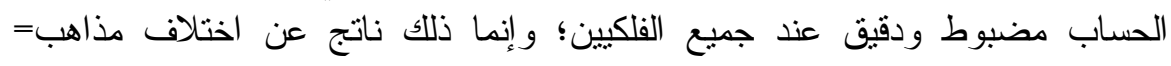




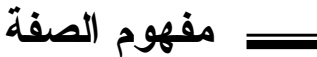

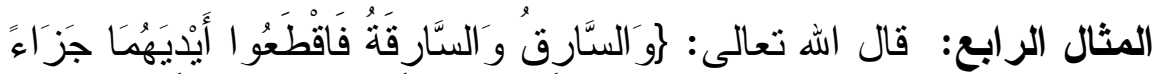

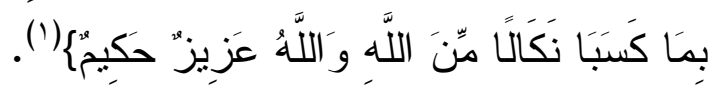

$=$

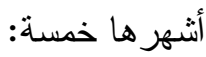

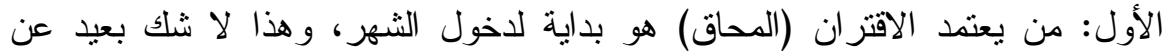
النص، لأن الله ربطنا في كتابه ورسولنا صلى الله عليه وسلم في سنته بالهلال ورؤيته لأله

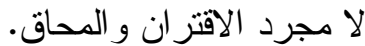

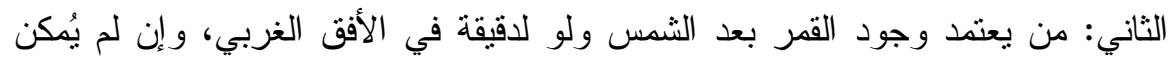

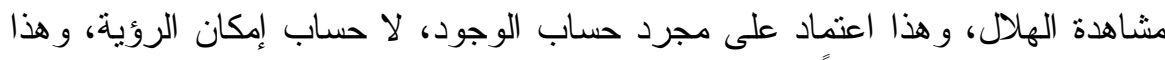
المذهب أهمل الرؤية تماماً.

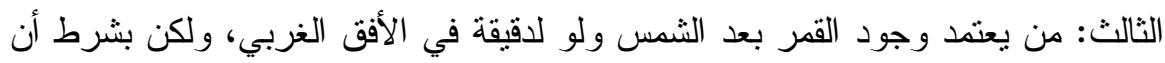

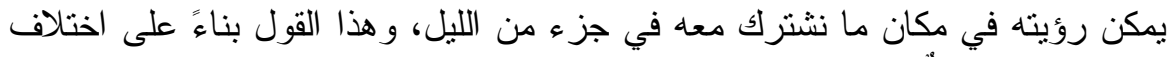

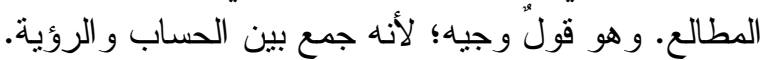

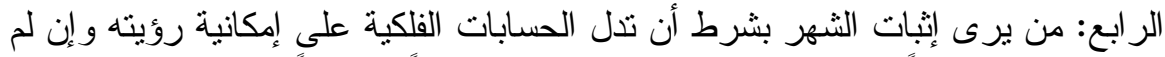

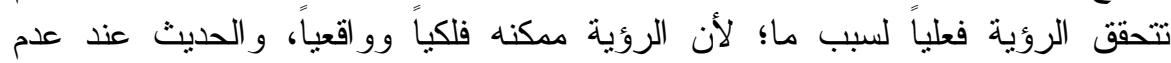

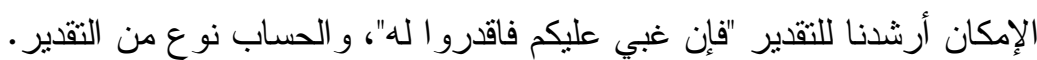

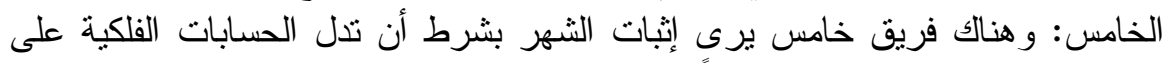

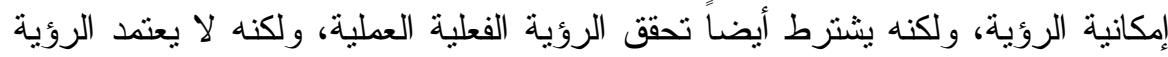

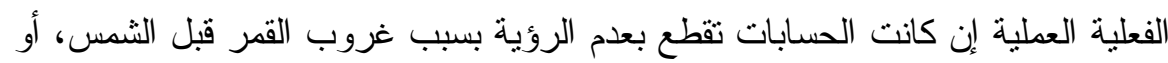
عدم حدوث الاقتران قبل الغروب، وهذا القوات القول هو ما أقره كثير من الفقهاء المعاصرين وهو اعتماد الحسابات في النفي لا الإثبات.

هذه هي أثنهر مذاهب الفككيين في إثنات الثهر العربي، وكل هذا الاختلاف لا يعني

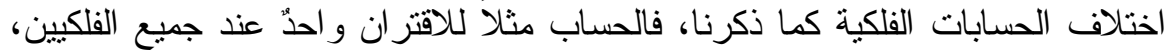

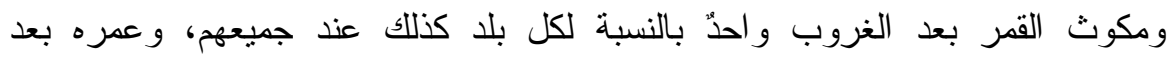
الاقتر ان متفق عليه كذلك، و هذه هي الحسابات التي لا يختلف عليها فلكيان البنة، و التي هي أساسات الحسابات الفلكية. ومن هنا تعرف غلط بعض الفقهاء في الاستخلال باختلاف مذاهب الفكلكيين على بطلان

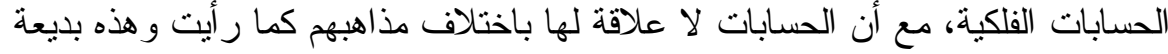
فتأملها!". د. صلاح الدين أحمد محمد عامر . علم المو القيت القات القبلة و الأهلة من الناحيتين

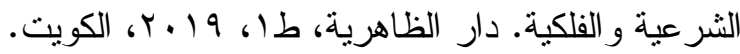

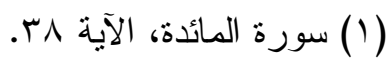


وتعريف السرقة كما جاء في القاموس المحيط: السرق منه الثيء يسرق

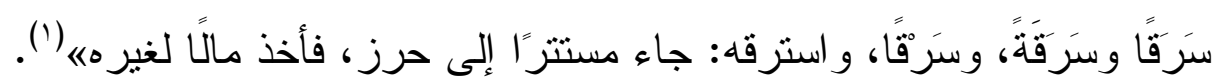

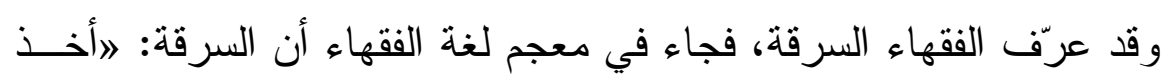

ما هو مملوك للغير خفية، و السرقة الموجبة للقطع: هي أخذ المكلف نــصاءًا

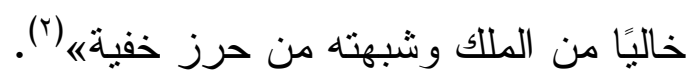

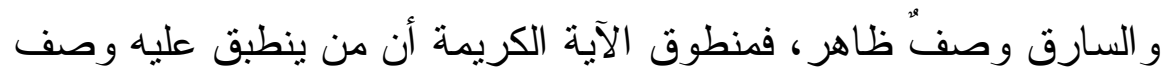

السارق فيجب إقامة الحد الثرعي عليه، ومفهوم الصفة هنا أن غير الـسارق لا يقام عليه الحد الثرعي بالقطع، ووصف السرقة ضبطه الفقهــاء بـشروط مفصلة في كتبهم الفقهية، مما يجعل بعض مسائل السرقة المعاصــرة مجـــالاً للبحث الأصولي الفقهي: هل هي مما ينطبق عليه وصف السرقة أم هي مدــا

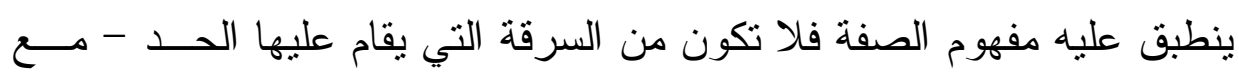
التسليم بالنهي عموماً عن أخذ أمو ال الناس بالباطل بأي طريقة كانت-؟ عن فمثناً:

حقوق الملكية الفكرية، وحقوق التأليف، و العلامات التجاريـــة، وســرقة المعلومات الإلكترونية.

هل يكون التعدي عليها من ضمن معنى السرقة التي يقام عليها الحد؟ أو

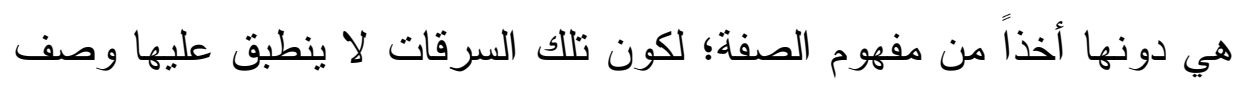
السارق بالمعنى الثرعي؟

ومعلومُ أنها تُعتبر اليوم قيمةً ماليةً اعتبارية، وهذه من المسائل المعاصرة

المستحدثة.

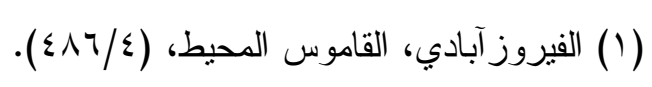

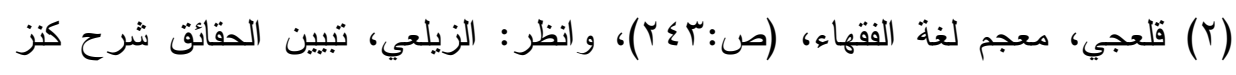

الدقائق، (Y/Y)

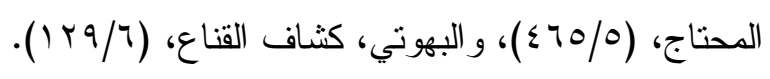




\section{=}

وقد ذهبت بعض المجامع الفقهية إلى كونها حقوقًا وأمو الاً، فجاء في قرار

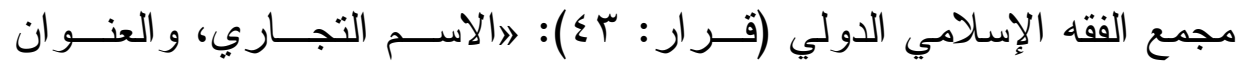

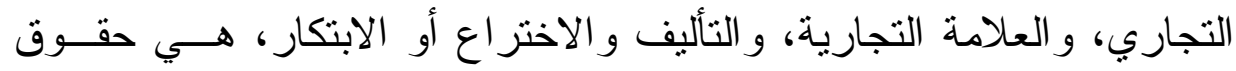

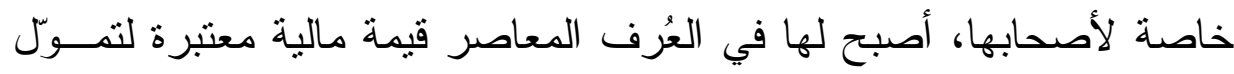
الناس لها، و هذه الحقوق يعتد بها شرعًا فلا يجوز الاعتداء عليهاه.

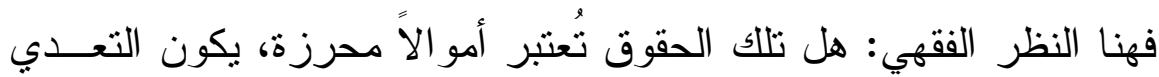

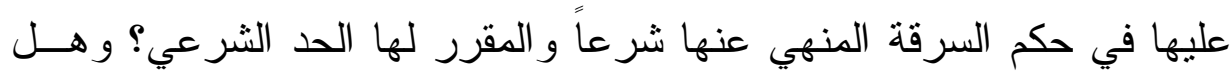

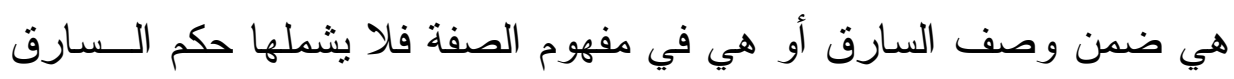

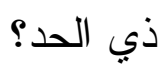

المثال الخامس: تطبيق مفهوم الصفة من بعض الفتاوي القديمة جزئيًّا أو كليَّا في النوازل المعاصرة: فمعرفة الفتاوى السابقة تعطي صورة عن النازلة في عهدها السابق وتطورها الذي جد في الوقت اللاحق، و الفقبه حينما يطالع مسالك الفقهاء في تقعيد حكم المسألة الفقهي يسهل عليه بحث النازلة، فربما أنزل حكم المتقدم

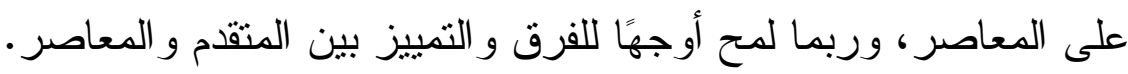

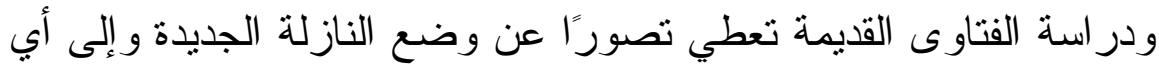
مدى يمكن اعتبارها نازلة من كل وجه، وهذا قد يفيد في تكييفها، ومن ثم استتباط الحكم المناسب لها. وفي التراث الفقهي المذهبي القديم ما يشير بجاء إلهاء إلى مآخذ أحكام

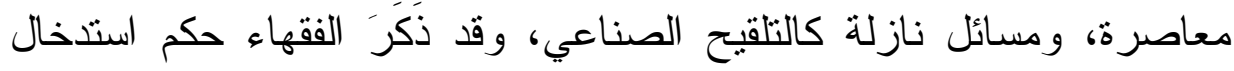

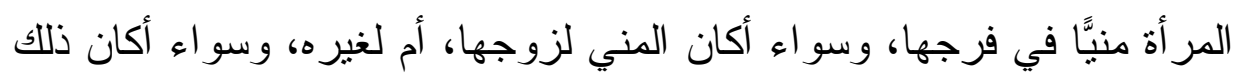




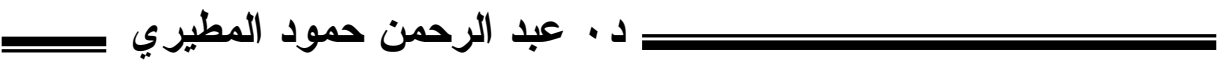
لشهوة، أم لا؟ وسواء أكان ذلك عن قصد، أم لا؟ بما يمكن أن يكوَّن أمار ات ترشد إلى حكم التلقيح المجهري و الصناعي اليوم ('). وفي التراث الفقهي المذهبي ما يتتاول حكم الوفاة الدماغية، وما يثرتب عليها؛ فقد تتاول الفقهاء حكم من جرح فلم تبق فيه إلا منل حركة المذبوح بحيث يعمل قلبه و أعضاؤه تتحرك حركة لا إر ادية؛ فهل بحكم له بالحياة، أم لا؟ وما حكم من جنى عليه في هذه الحالة، وهل يعد قاتنًا، أم لا؟(؟). يقول محمد يسري إبر اهيم عن منل هذه الفتاوى القديم: اوينبغي التتبه إلى أن دلالة تللك الفتاوي القديمة على النوازل المستجدة قد لا تكون بطريق المطابقة، وإنما بطريق التضمن أو اللزوم، وقد لا تكون بمفهوم الموافقة، و إنما قد تكون بمفهوم المخالفةه(r)، الذي أحد أنو اعه مفهوم الصفة.

(1) قال البهوتي: 》أو استخخلت المرأة منيه بقطنة أو نحوها، فلا تحرم بنتها عليه لعدم

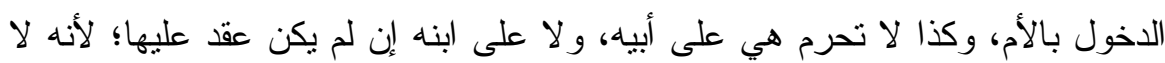
عقد ولا وطء، نقله في الإنصاف عن التعليق و اقتصر عليه، وهو مقتضى كلام التتقيح

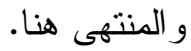
وقال في الرعاية: ولو استخخلت مني زوج أو أجنبي بشهوة ثبت النسب والعدة و المصاهرة، وتبعه في المنتهى في الصداقه، كثاف القناع عن منت الإقناع، (VT/0).

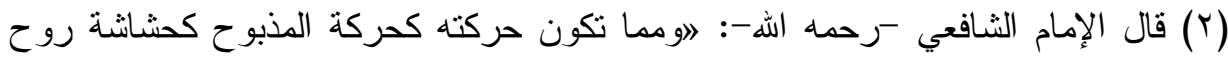
الحياة التي لم يتتام خروجه، فإن خرج إلى هذا فلا يضره ما أصابه؛ لأنه قد أصابه وهو

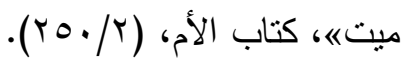

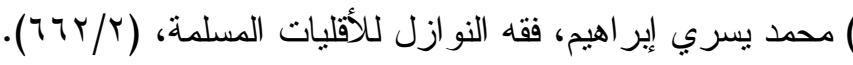




\section{مفهوم الصفة}

\section{الخاتمة}

بعد هذا التطو اف في كتابتي هذا البحث - و الذي يتتاول موضوعاً مهماً،

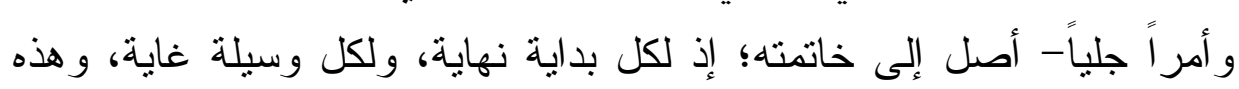

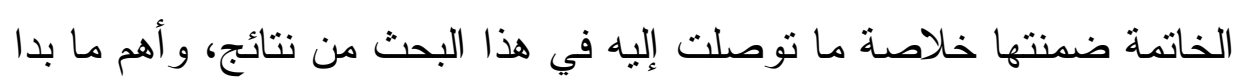
لي من فو ائد، عل الله أن ينفع بها المسلمين و المسلمات.

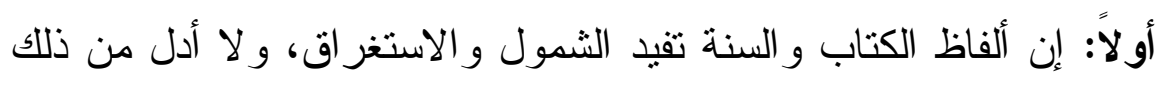

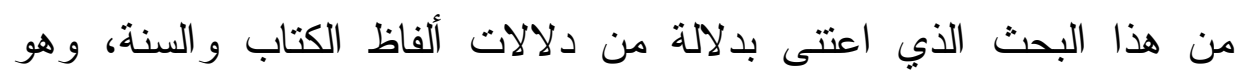

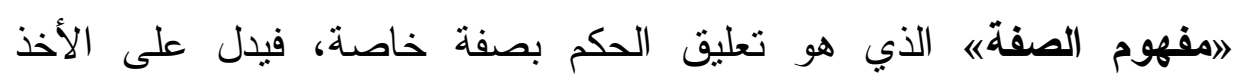

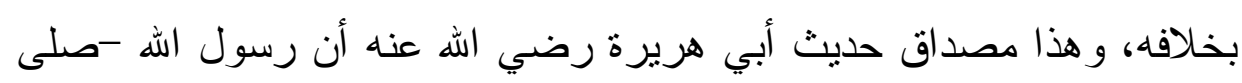

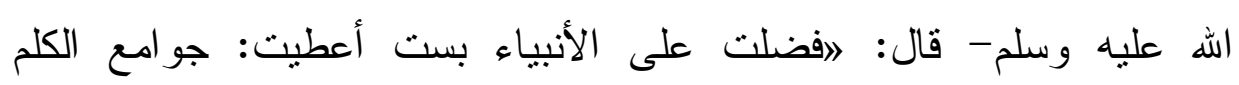

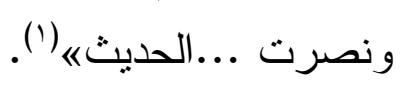

فال البخاري -رحمه الله- اوبلغني أن جوامع الكلم: أن الله يجمع

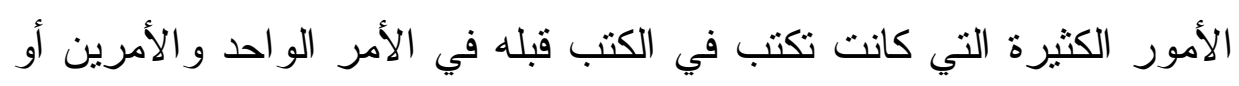

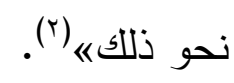
ثانياً: اتضح من هذا البحث كيف حرر العلماء دلالات ألفاظ الكتاب

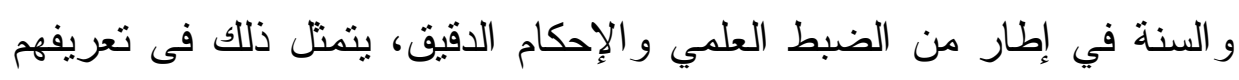

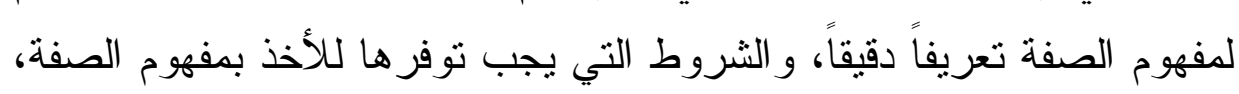

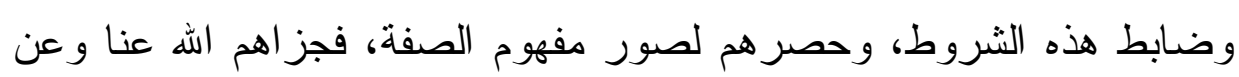

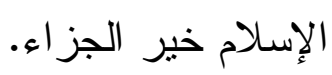

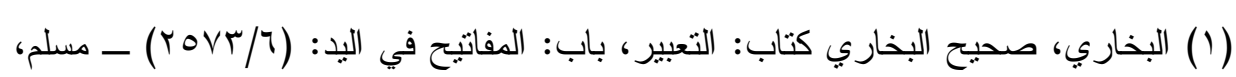

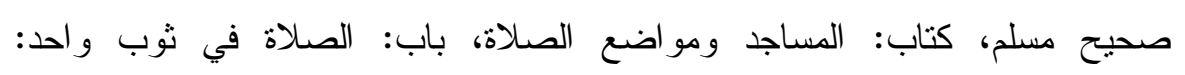

$$
\text { (r) صحيح البخاري: (rovr/T). }
$$




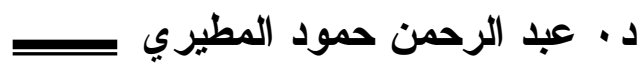

ثالثاً: إن التعريف المختار لمفهوم الصفة هو عبارة عن: التعليق الحكم بصفة خاصة فيدل على الأخذ بخلافهـ.

و إن المر اد بالصفة عند الأصوليين: اتقييد لفظ مشترك المعنى بلفظ آخر

$$
\text { يختص ببعض معانيه ليس بشرط و لا غايةه. }
$$

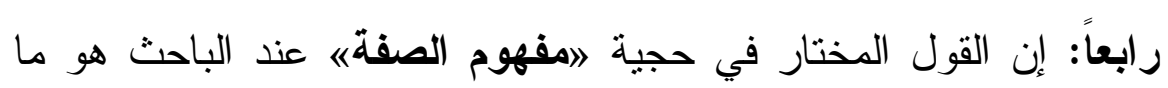
ذهب إليه الأئمة مالك والثافعي وأحمد بن حنبل وجماعة من الفقهاء و المتكلمين وجماعة من أهل العربية، وهو أن مفهوم الصفة حجة، أي: يدل على نفي الحكم عند انتفاء الصفة، و إنه لا بد من التأصيل عليه والأخذ به

$$
\text { سو اء في المسائل المستحدثة أو غير ها. }
$$

خامساً: للعمل بمفهوم الصفة على وجه الخصوص وبمفهوم المخالفة على وجه العموم شروط، بعضها راجع للمسكوت عنه، وبعضها راجع للمذكور، و الضابط لهذه الثروط وما في معناها: ألا بظهر لتخصيص المنطوق بالذِّرِ

$$
\text { فائدة غير نفي الحكم عن المسكوت عنه. }
$$

سادساً: إن مفهوم الصفة محصور في سبعة صور ، وهي ذكر الصفة الخاصة بعد اسم عام، أو تعليق الحكم على صفة لا تستقر، أو ذكر قسمين مع

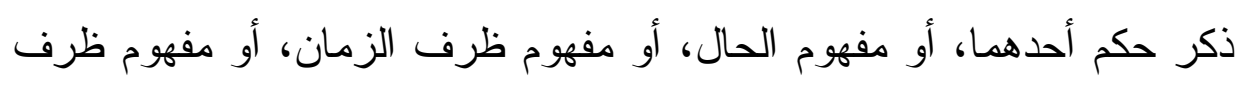
المكان، أو مفهوم العلة.

سابعاً: لقد كان لاختلاف أنظار الأصوليين إلى „مفهوم الصفةها، من

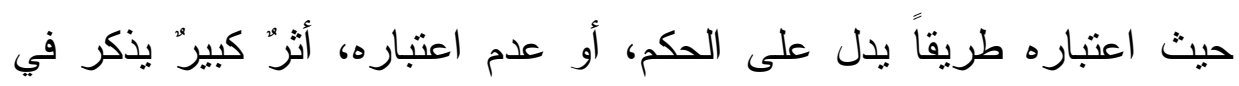
الفروع و الأحكام، وقد ثم استعر اض العديد من الأمثلة في هذا البحث. ثامناً: يمكن لتطبيق 》مفهوم الصفةه بضوابطه وشروطه أن يفيد في الاستتباط لعدد من المسائل المعاصرة المستحدثة، مما يسهم في تجدد حركة الاجتهاد الفقهي و النظر الاستدلالي فيما يستجد من مسائل وقضايا معاصرة. 
تاسعًا: الفقيه سوم اءًا كان قاضيًا أم لا - لا يقتصر في الحكم على الأثشياء

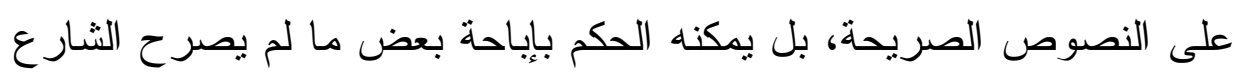

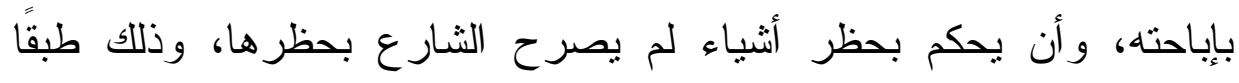
لمفهوم الصفة و غيره من دلالات الألفاظ.

و هذا مما امتاز به فقهاء الثريعة على فقهاء القانون في مجال التهات التجريم

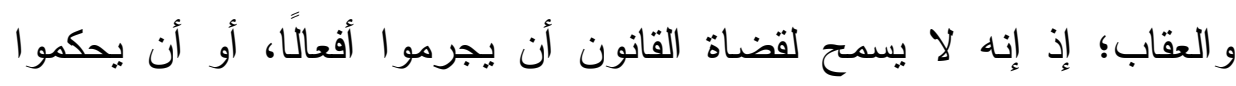

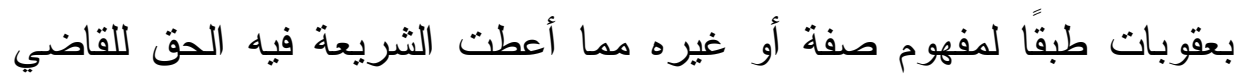
بالاجتهاد فيه. 
בـ الرحمن حمود المطيري

\section{التوصيات}

أوثًا: هناك حاجة ملحة لإتقان اللغة العربية فيما يخص باب دلالات

الألفاظ؛ إذ فيه ثزوة عظيمة تعين على فهم القر آن الكريم و السنة الثريفة.

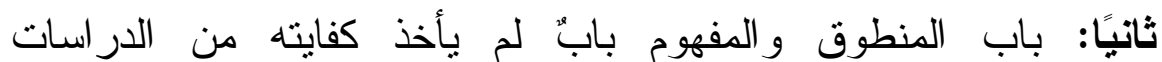
المتخصصة و الواسعة، ويرى الباحث أن على مختلف الكليات و المعاهد المتخصصة توجيه الطلبة للتوسع في هذين البابين.

ثالثًا: لا يز ال 》مفهوم الصفةه لم يأخذ حقه الكامل من الدر اسة و البحث، ويرى الباحث أن هناك حاجة ملحة لتوجيه الأنظار إلى هذا المبحث الأصولي؛ إذ له تعلق كبير بالاستتباط الفقهي لدى مختلف المدارس الفقهية السنية. رابعًا: يدعو الباحث مجامع الفتوى ومجامع الفقه للاستعانة بمبحث ״فهوم الصفةه في استتباط الأحكام الثرعية للمسائل المعاصرة المستجدة؛ حيث استقر أت كثيرًا من الأبحاث في النوازل الفقهية المعاصرة فلم أجد من استخل بمفهوم الصفة إلا نادرًا! خامسًا: يدعو الباحث المؤلفين و الكُّاب في مجال أصول الفقه عموماً ومجال دلالات الألفاظ خصوصاً إلى التطرق لأمثلة جديدة في باب لإمفهوم الصفةها، إذ هناك أمثلة ثناث أو أربع، تتكرر في أغلب الكتب القديمة

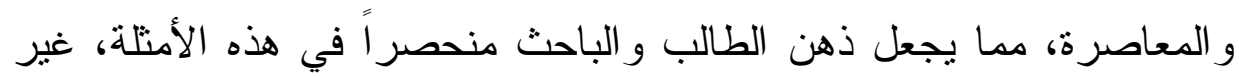
قادر على الغوص أكثر في تطبيقات هذا الباب 》مفهوم الصفةه في مسائل الفقه قديماً وحديثًا.

سادسًا: يدعو الباحث إلى تظافر الجهود وتكثيفها في سبيل خدمة الثريعة الإسلامية وخدمة أصولها الذي هو الباب الرئيسي للاستتباط و الاجتهاد، مما يزيد من العناية بالإسلام كمصدر تشريع متجدد، ويظهر مواضع الجمال في هذا التشريع الرباني العظيم. 


\section{=}

وفي الختام أسأل اله الكريم أن يغفر لنا ما جرى وما يجري منا من

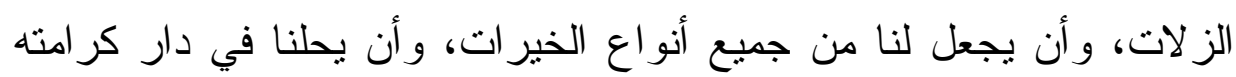

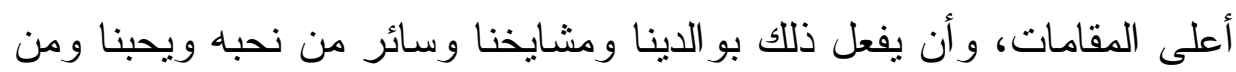

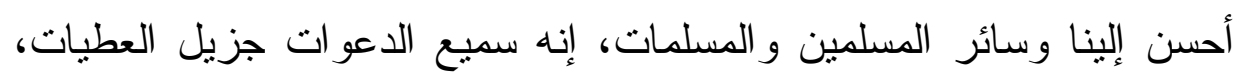

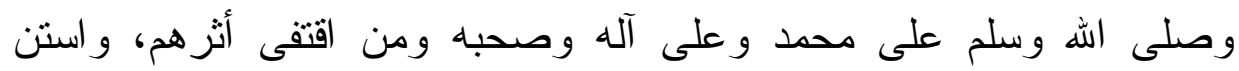
بسنتهم إلى يوم الدين، و آخر دعو انا أن الحمد لله رب العي العالمين. 
د. • عبد الرحمن حمود المطيري حس

$$
\text { فهرس أهم المصادر والمراجع لهمن المعود }
$$

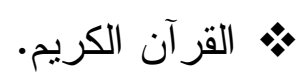

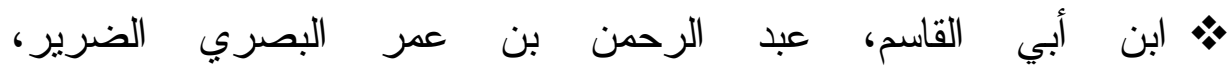

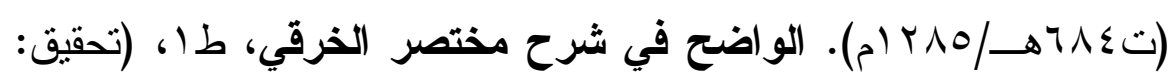

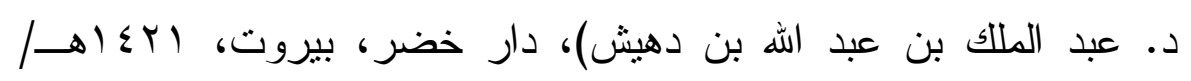

$$
\cdot \text {. }
$$

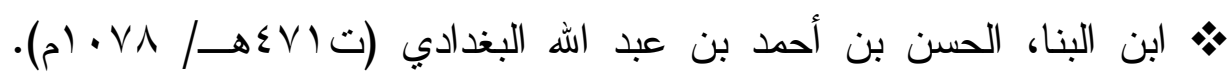
المقتع في شرح مختصر الخرقي، طب، (تحقيق: د. عبد العزيز بن سليمان

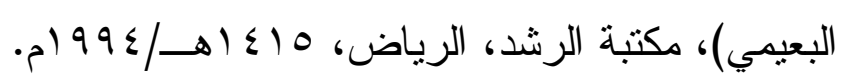

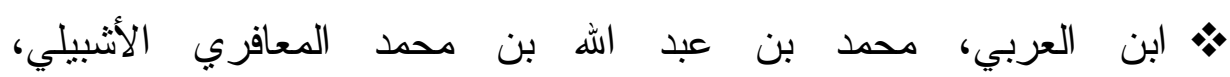

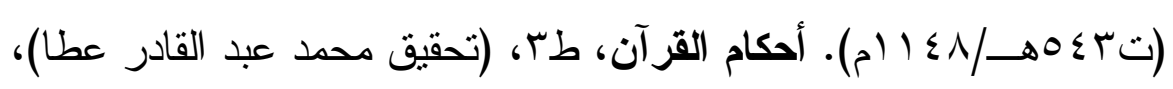

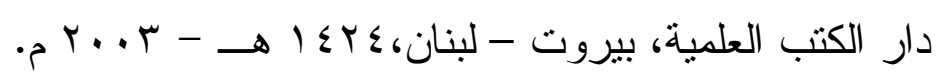

• ابن العربي، محمد بن عبد الله بن محمد المعافري الأشبيلي،

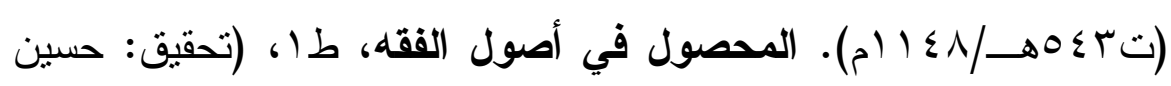

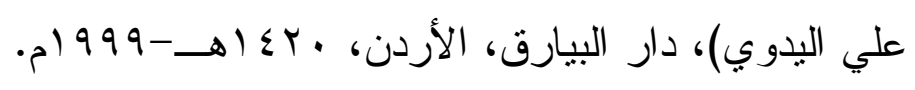

• ابن العربي، محمد بن عبد الله بن محمد المعافري الأشبيلي،

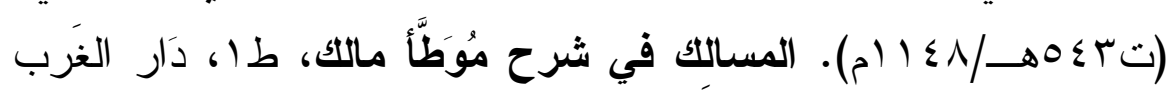

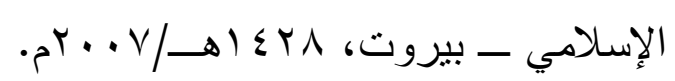

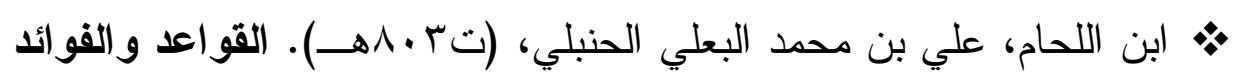
الأصولية وما يتعلق بها من الأحكام، (تحقيق: محمد حامد الفقي)، مطبعة

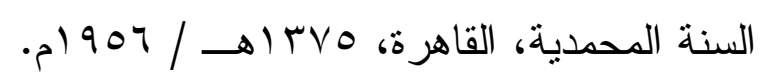

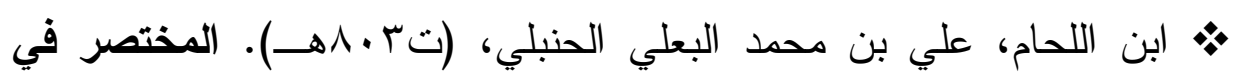
أصول الفقه على مذهب الإمام أحمد بن حنبل، (تحقيق: د. محمد مظهر بقا)، جامعة الملك عبد العزيز، مكة المكرمة. 


\section{=}

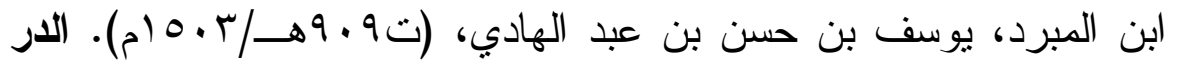

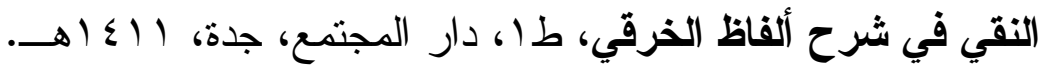

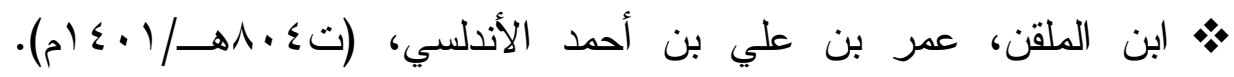
خلاصة البلر المنير في تخريج كتاب الثرح الكبير للرافعي، طا ـأ (تحقيق:

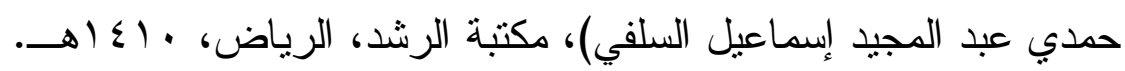

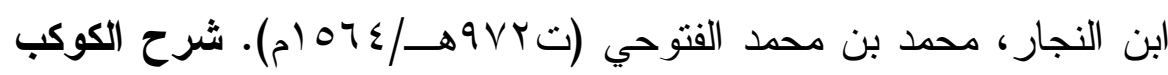

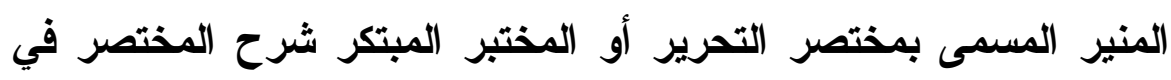

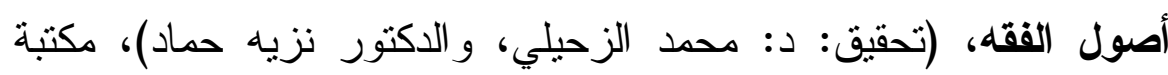

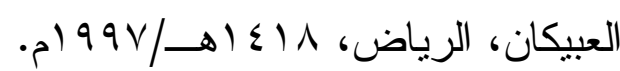

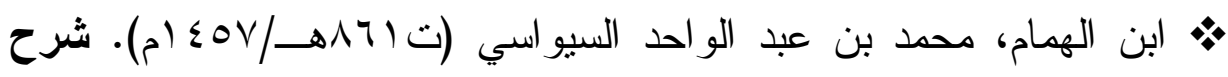

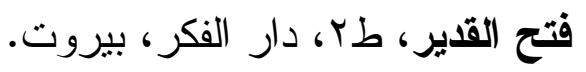

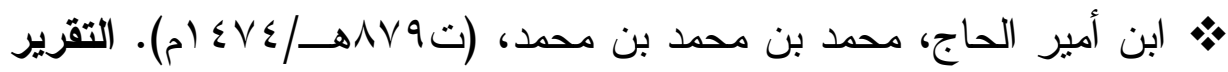

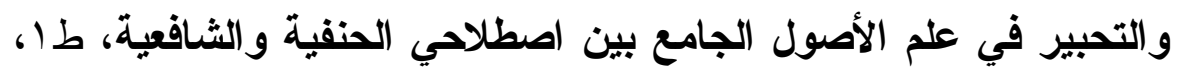
(تحقيق: مكتب البحوث و الدر اسات)، دار الفكر ، بيروت،

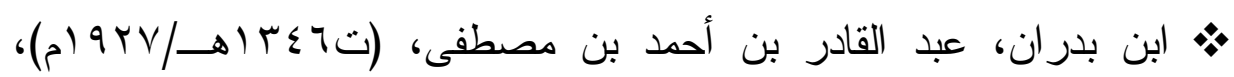

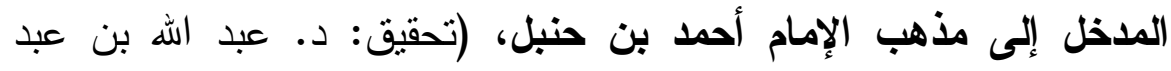

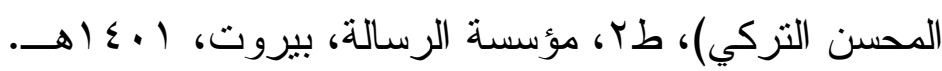

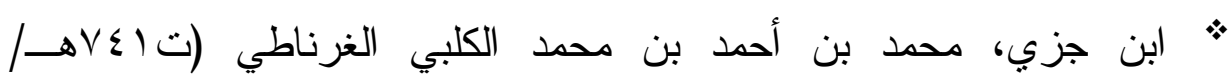

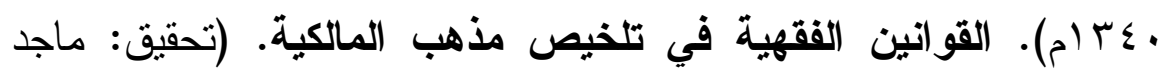

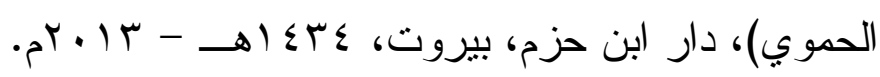

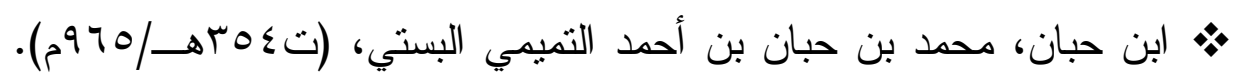
صحيح ابن حبان بترتيب ابن بلبان، طب، (تحقيق: شعيب الأرنؤوط)،

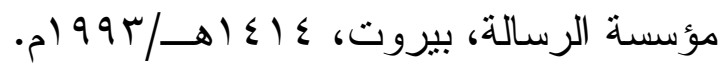


בد د عبد الرحمن حمود المطيري

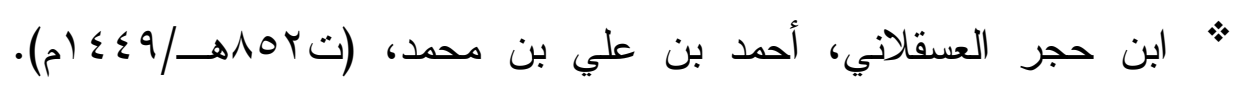

التلخيص الحبيز في أحاديث الرافعي الكبيز، طا، دار الكتب العلمية ــ

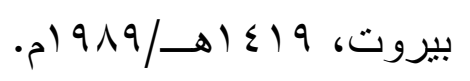

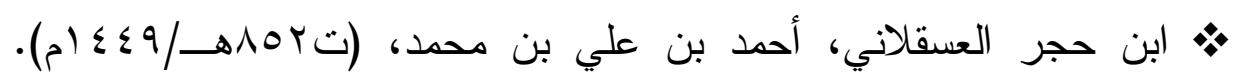

الارر الكامنة في أعيان المائة الثامنة، (تحقيق: محمد عبد المعيد ضان)،

الناشر : مجلس دائرة المعارف العثمانية، مكان النشر: حيدر آباد/ الهند،

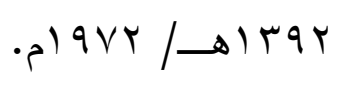

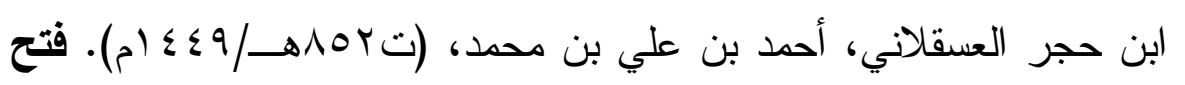
الباري شرح صحيح البخاري، (تحقيق: محمد فؤاد عبد الباقي - محب

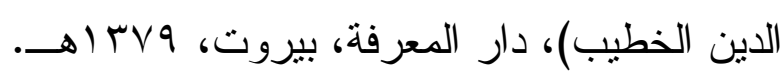

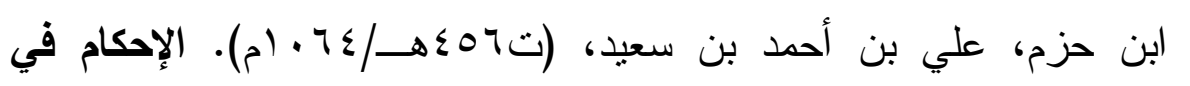

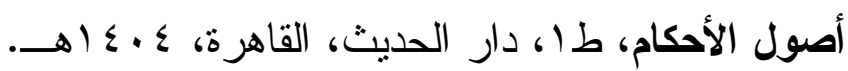

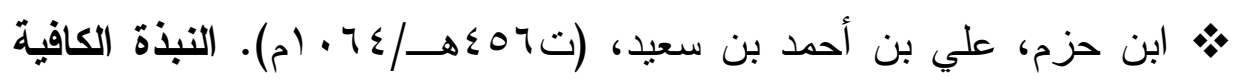
في أحكام أصول الاين، طا. (تحقيق: محمد أحمد عبد العزيز)، دار

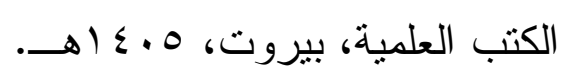

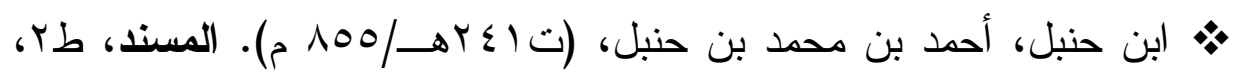

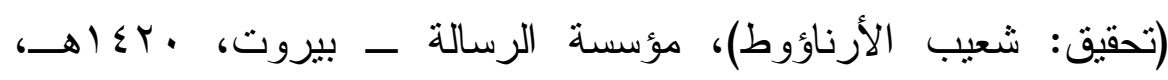
. $) 999$

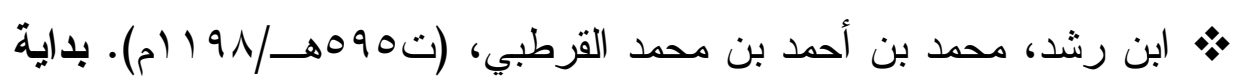

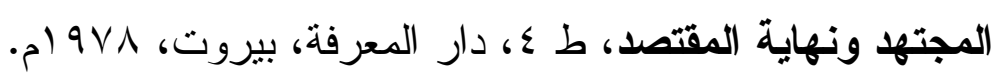

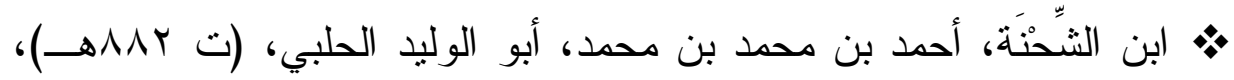
لسان الحكام في معرفة الأحكام، طب، الناثر : البابي الحلبي - القاهرة -

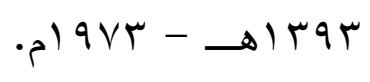




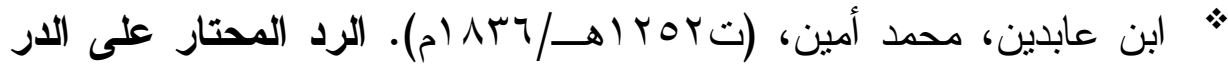
المختار المعروف " بحاثية ابن عابدين "، ط؟، دار الفكر، بيروت.

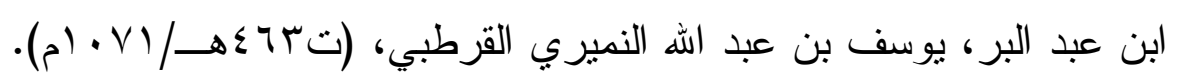

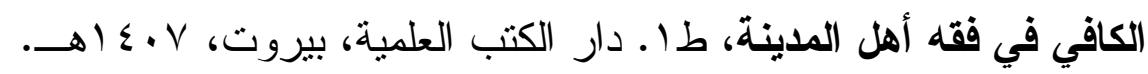

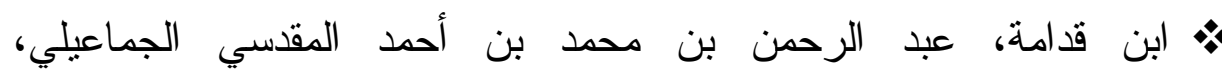

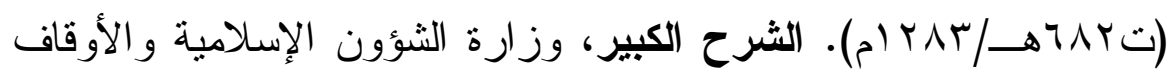

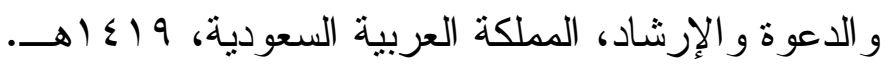

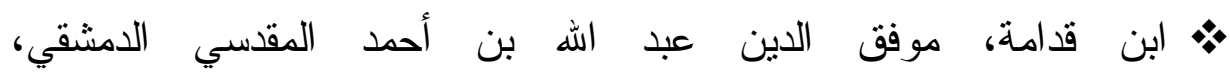

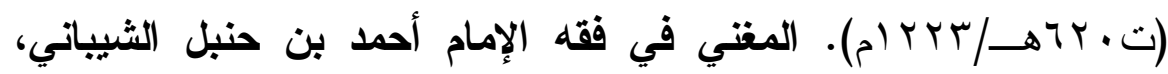
طا، دار الفكر، بيروت، 0.

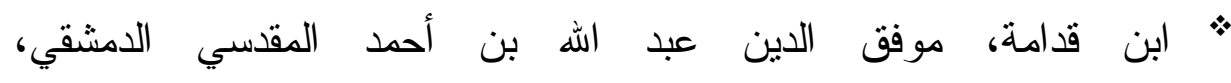

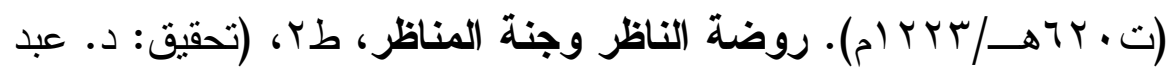

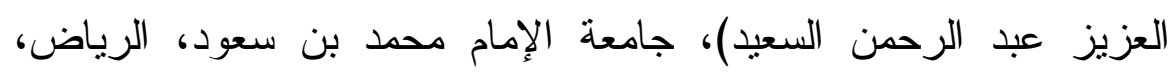

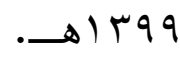

* " ابن قدامة، موفق الدين عبد اله بن أحمد المقدسي الدمثقي،

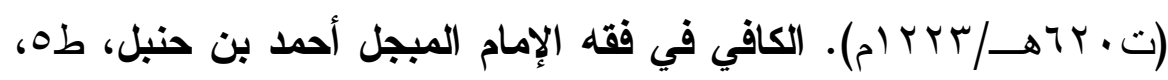

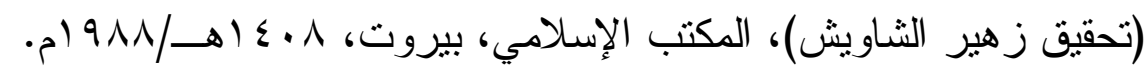

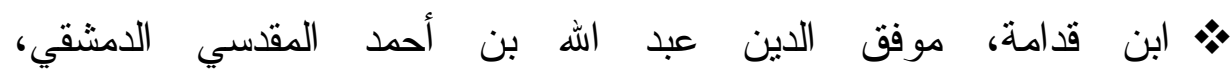

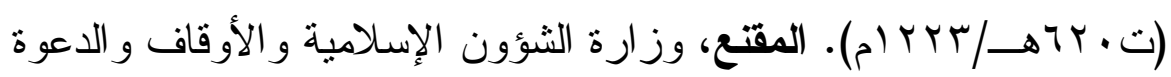

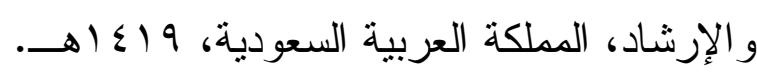

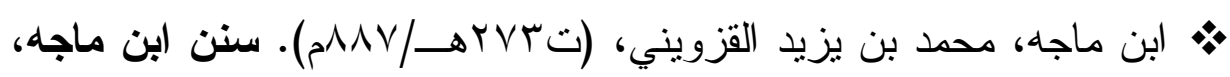

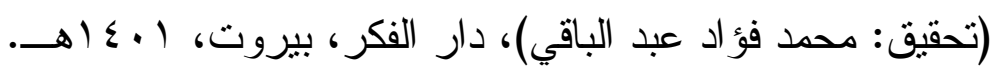

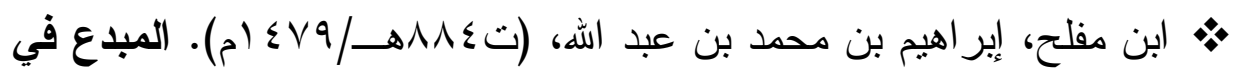

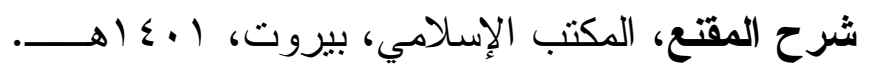


בد د عبد الرحمن حمود المطيري

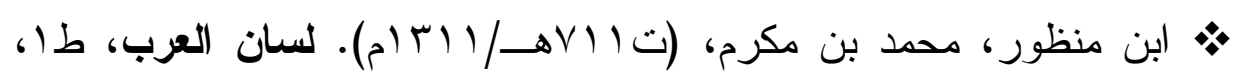
دار صادر ، بيروت. - مان.

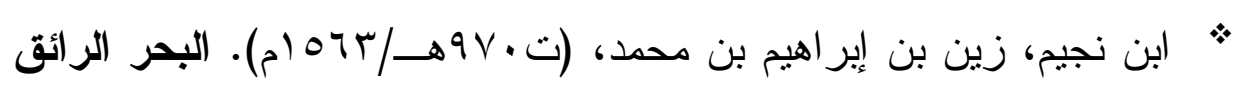
شرح كنز الاقائق، دار المعرفة، بيروت.

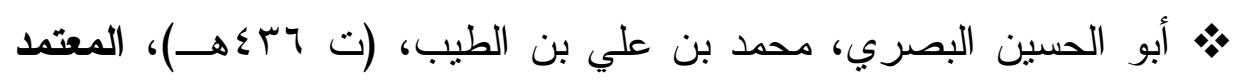
في أصول الفقه، ط ا، (تحقيق: خليل الميس)، دار الكتب العلمية،

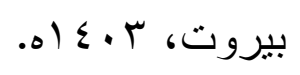
• أبو داود، سليمان بن الأشعث بن إسحاق بن بشير الأزدي الستِِّنْاني،

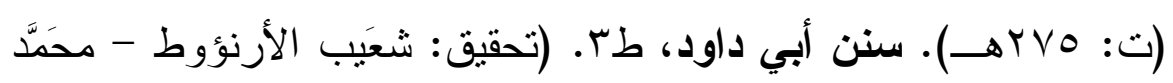

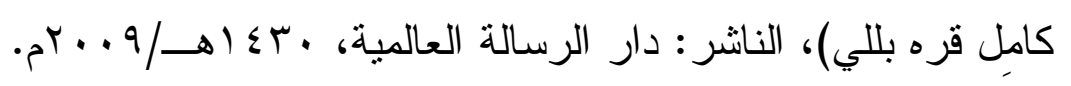

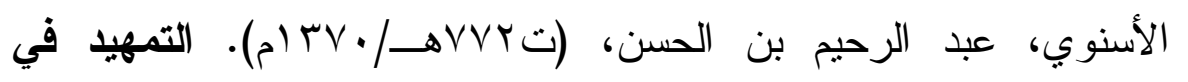
تخريج الفروع على الأصول، طا، (تحقيق: د. محمد حسن هيتو) مؤسسة

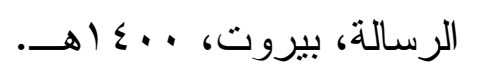

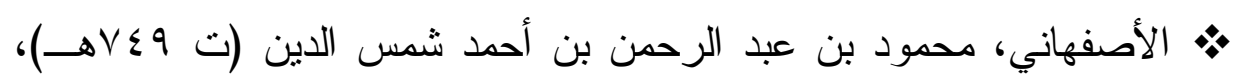
بيان المختصر شرح مختصر ابن الحاجب، طا ا، (تحقيق محمد مظهر بقا)،

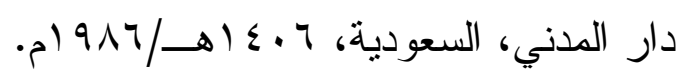

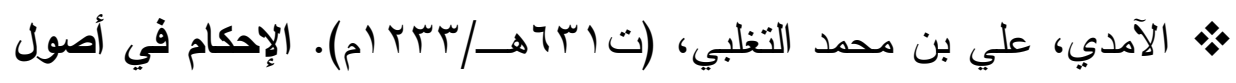
الأحكام، طا، (تحقيق: د. سيد الجميلي)، دار الكتاب العربي، بيروت،

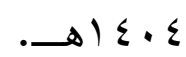

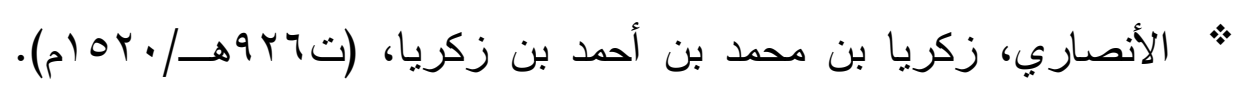

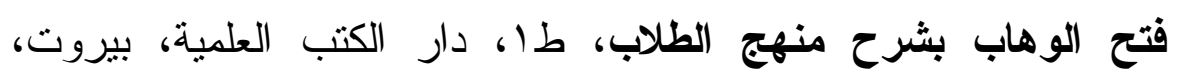
$\rightarrow 1 \leqslant$

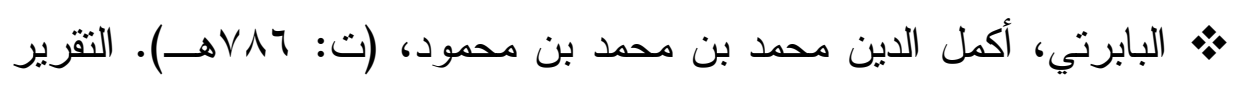
لأصول فخر الإسلام البزدوي، طا، (تحقيق: د. عبد السالم صبحي)،

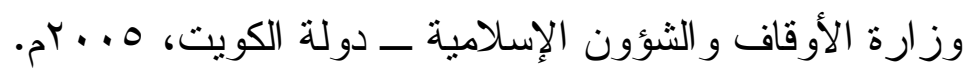




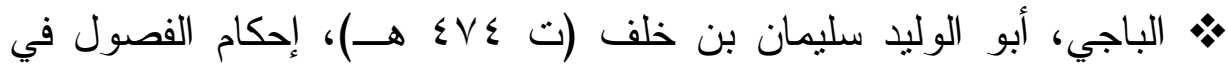

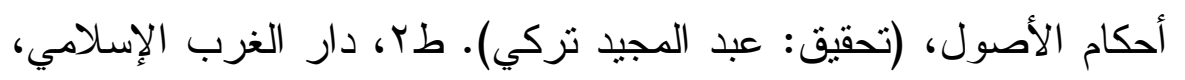

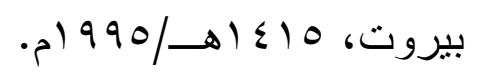

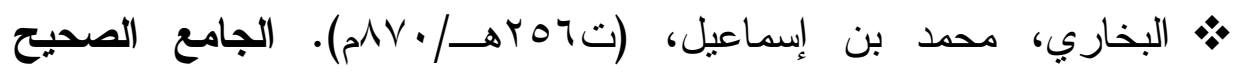

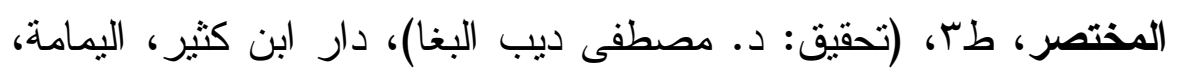

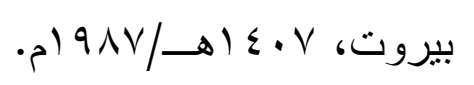

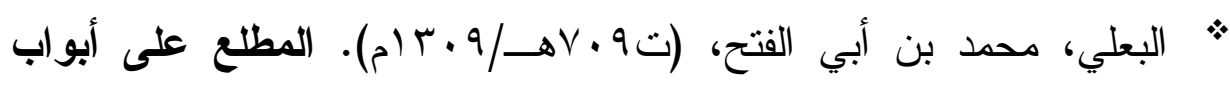

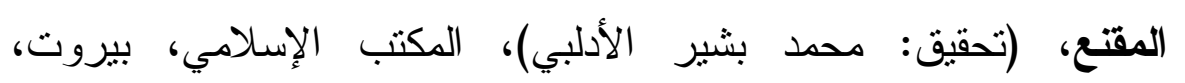

$$
\text { . }
$$

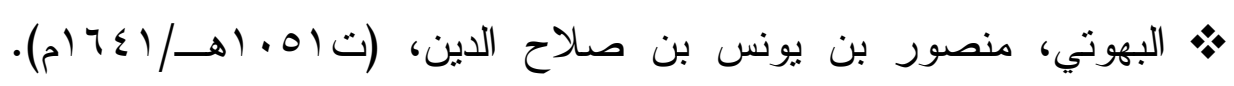

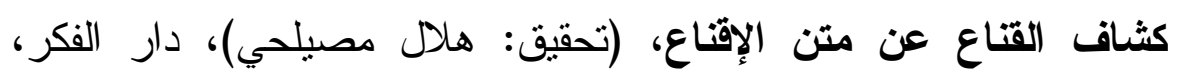

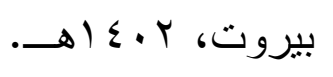

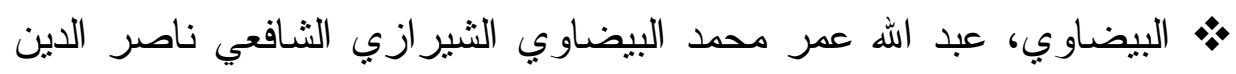

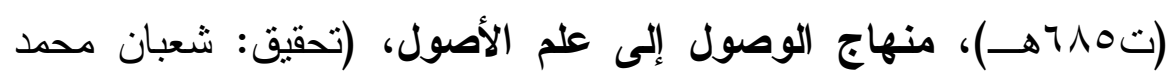

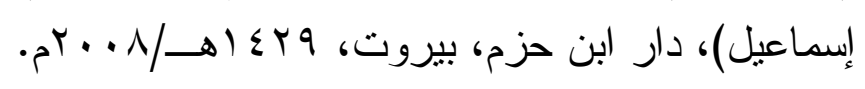

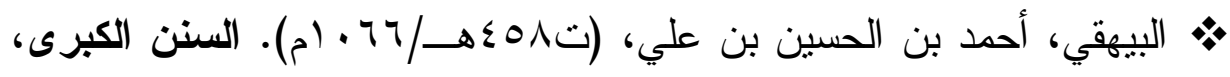

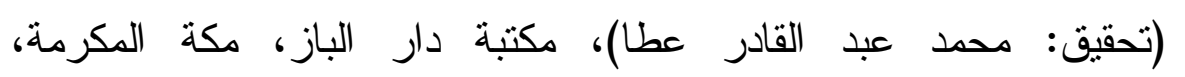

$$
\text { . } 99 \text { ( } 9 \text { (أ) }
$$

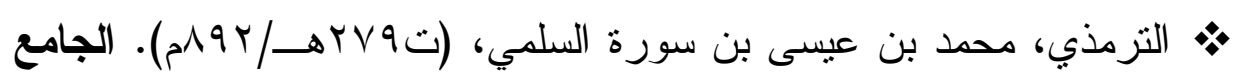

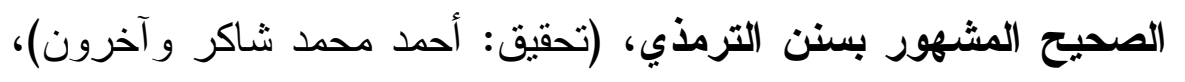
دار إحياء التزاث العربي، بيروت.

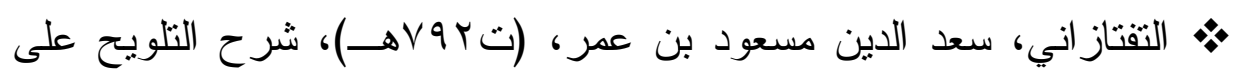

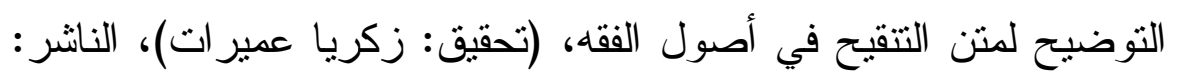

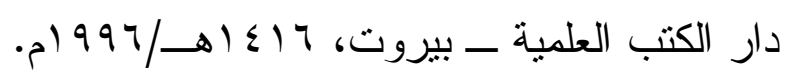




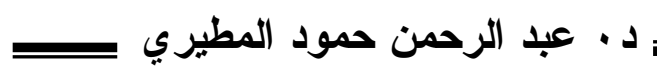

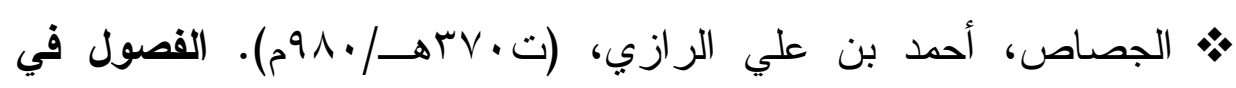
الأصول، طا، (تحقيق: د. عجيل جاسم النشمي) وزارة الأوقاف و الثئون

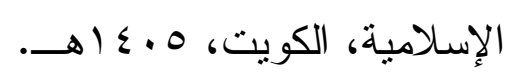

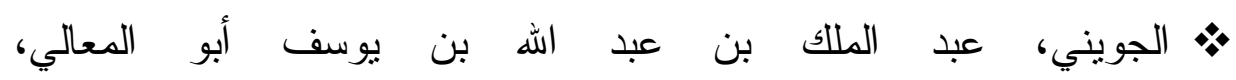

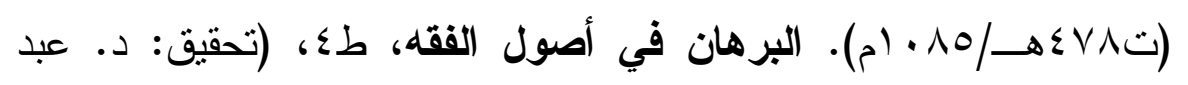

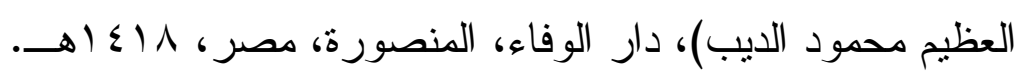

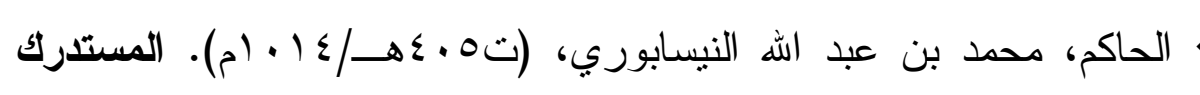
على الصحيحين، طا، (تحقيق: مصطفى عبد القادر عطا)، دار الكتب

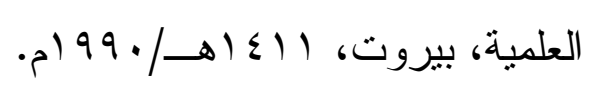

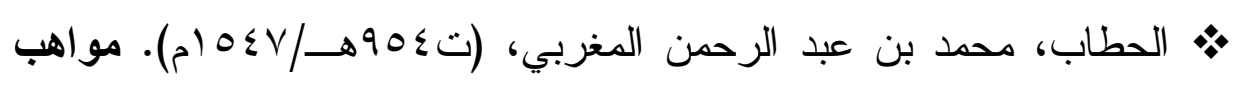
الجليل لشرح مختصر خليل، طب، دار الفكر، بيروت،

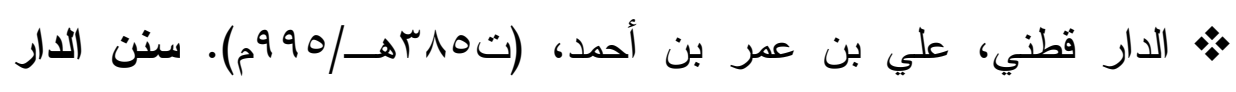

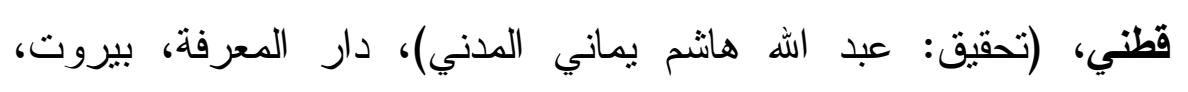

$$
\text { .م) } 977 / \text { ه إن }
$$

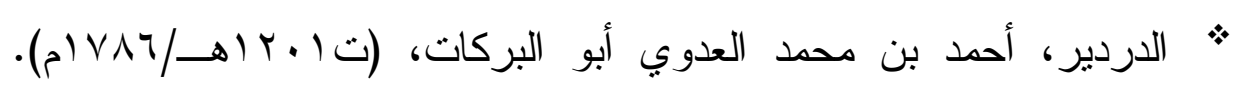
الشرح الكبير، (تحقيق: محمد عليش) دار الفكر، بيروت.

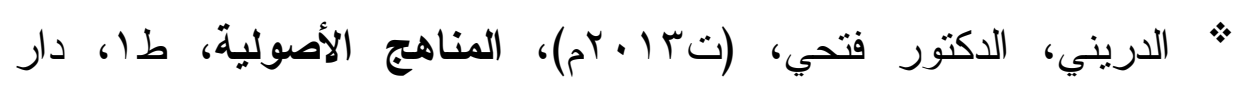

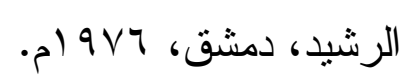

* الاسوقي، محمد بن أحمد بن عرفه، (ت.بr| هـ/10/1). الاسوقي على الشرح الكبير، (تحقيق: محمد عليش)، دار الفكر، بيروت.

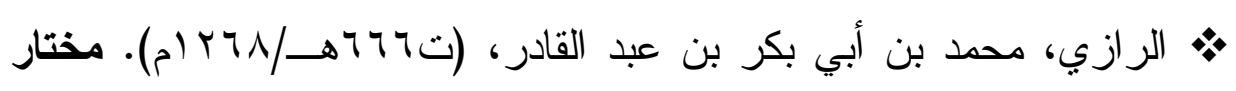
الصحاح، (تحقيق: محمود خاطر)، مكتبة لبنان ناشرون، بيروت، . $1990 / \rightarrow 1 \leqslant 10$ 


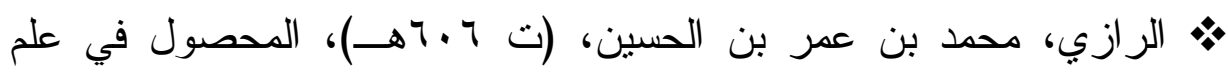

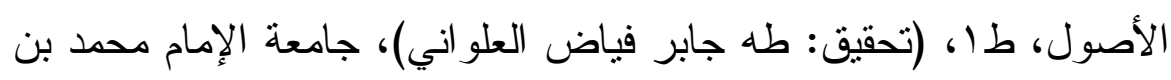

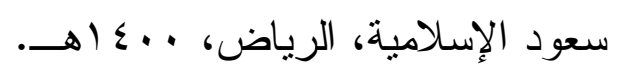

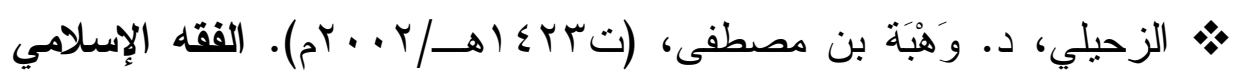

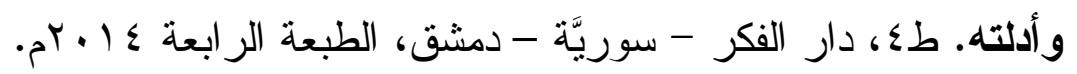

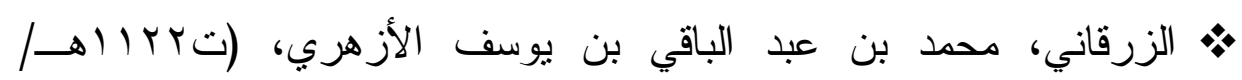
• بيروت، الإ اهـ.

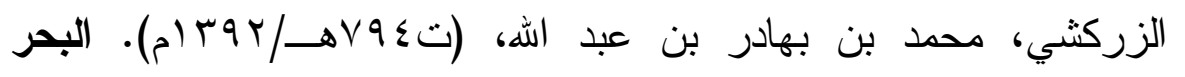

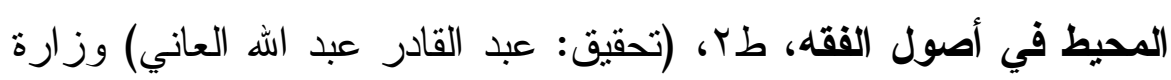

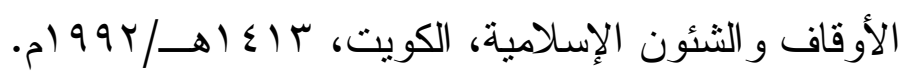

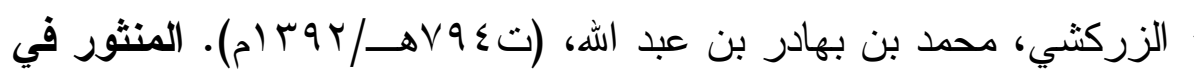

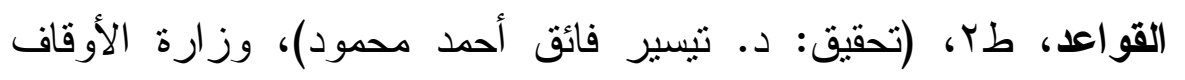

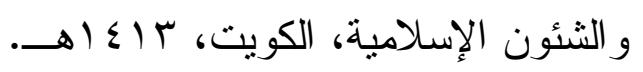

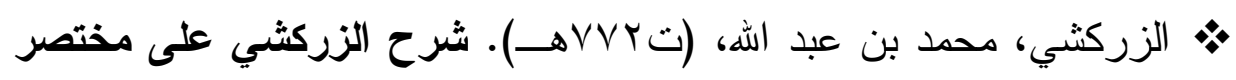
الخرقي في الفقه على مذهب الإمام أحمد بن حنبل، طا، (تحقيق: عبد الله

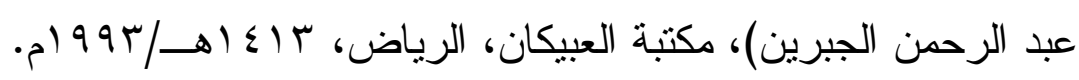

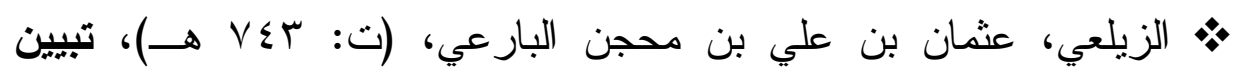

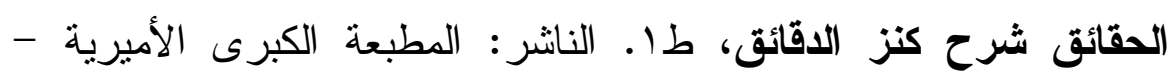

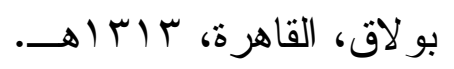

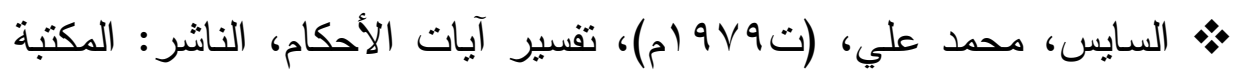

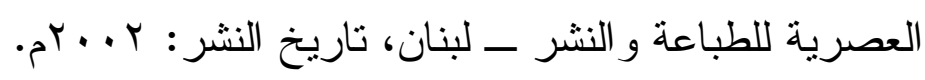




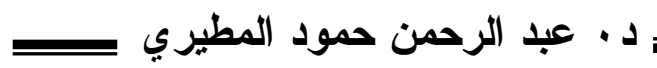

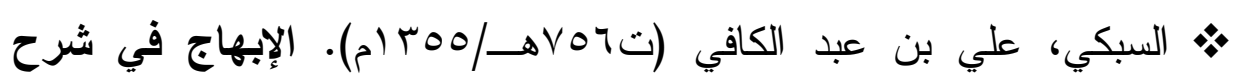
المنهاج على منهاج الوصول إلى علم الأصول للبيضاوي، طا، دار الكنب

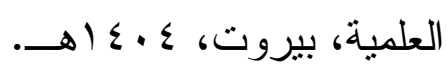

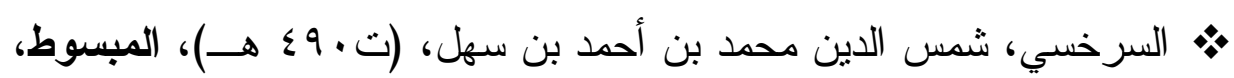
طا، (تحقيق: خليل محي الدين الميس)، دار الفكر للطباعة والنشر

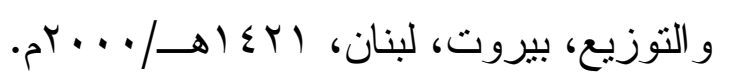

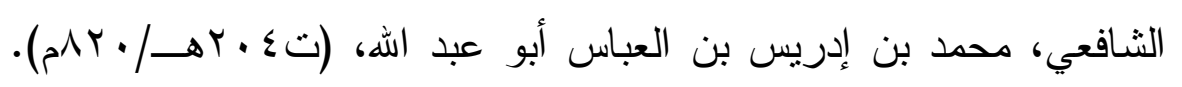

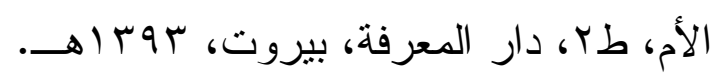

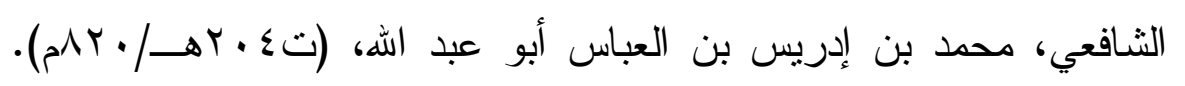

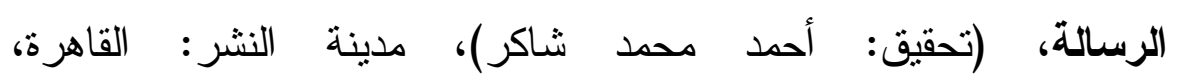
. $1949 / 3 \rightarrow 01$

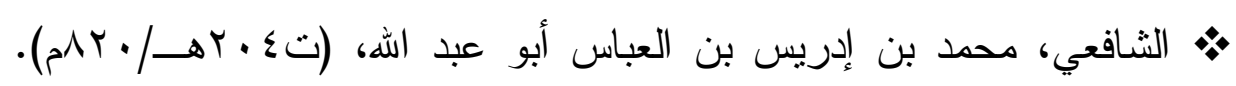
مسند الشافعي، دار الكتب العلمية، بيروت.

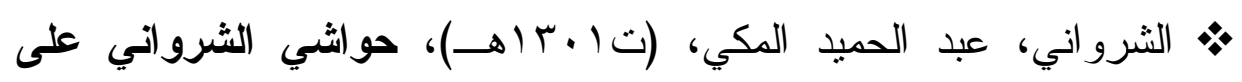
تحفة المحتاج بشرح المنهاج، الناشر : دار الفكر، بيروت.

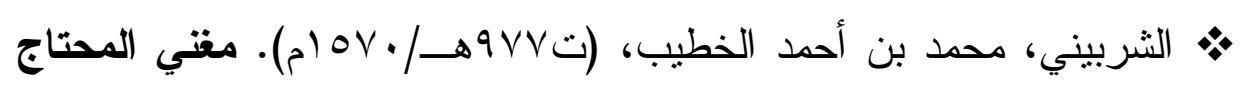
إلى معرفة معاني ألفاظ المنهاج، دار الفكر ، بيروت.

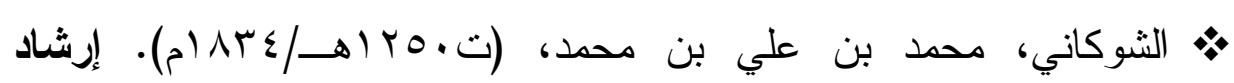
الفحول إلى تحقيق علم الأصول، طا، (تحقيق: محمد سعيد البدري)، دار

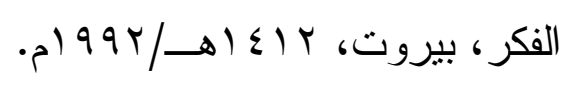

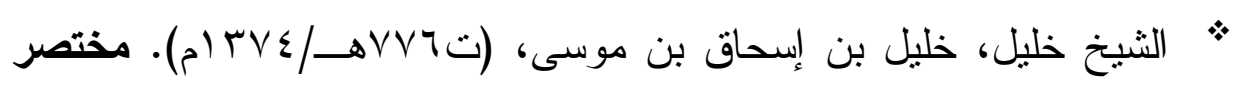

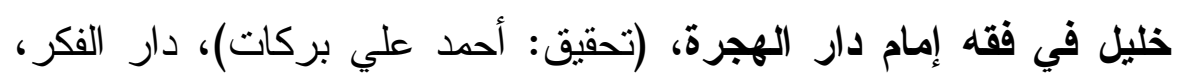
بيروت، أهي أهـ 


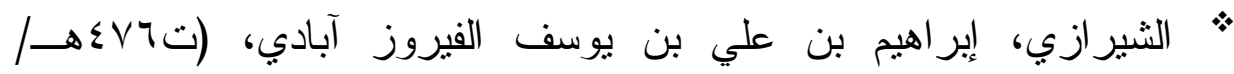

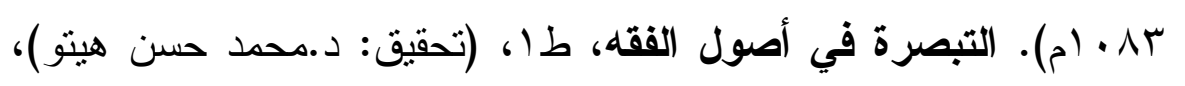

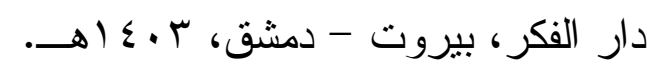

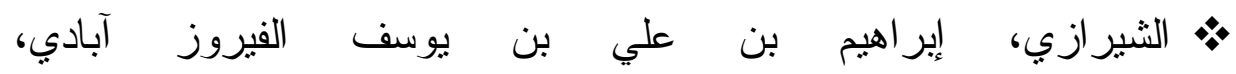

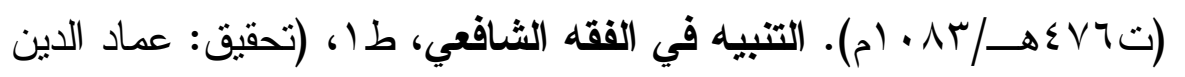

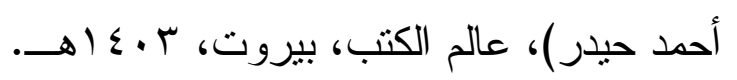

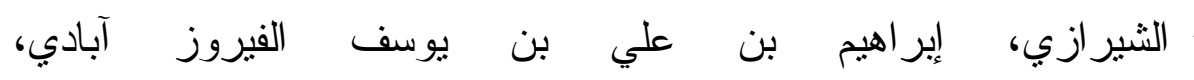

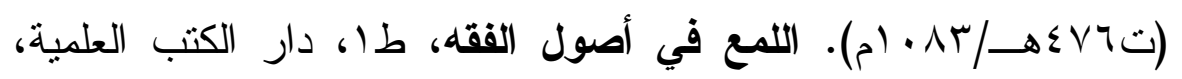

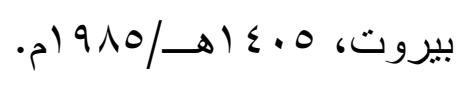

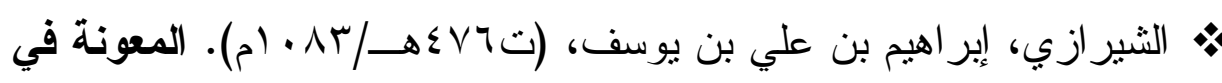

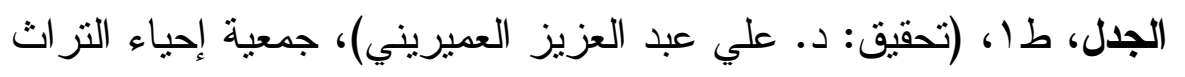

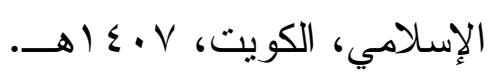

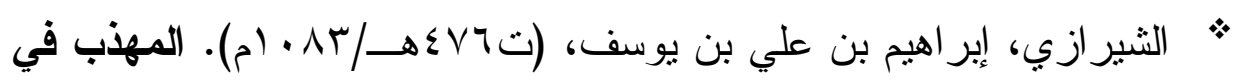

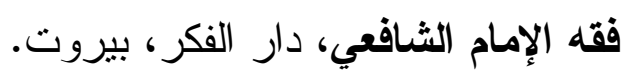

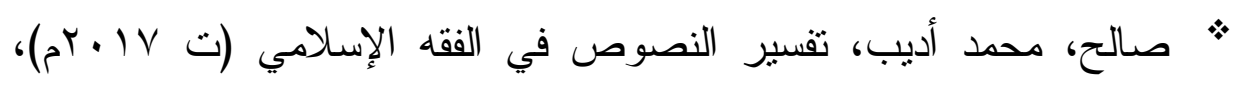

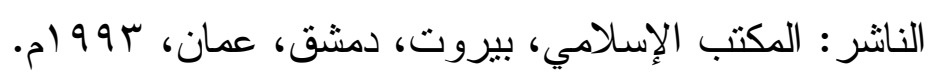

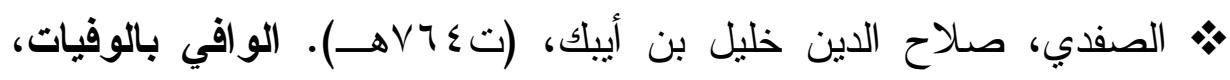

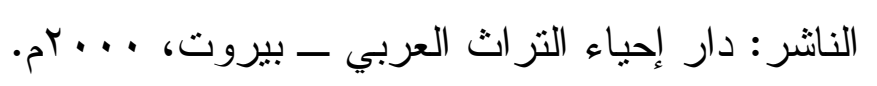

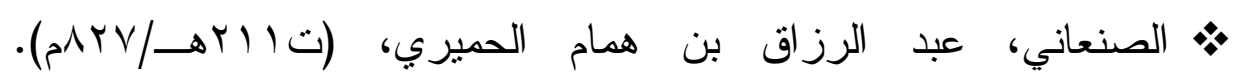

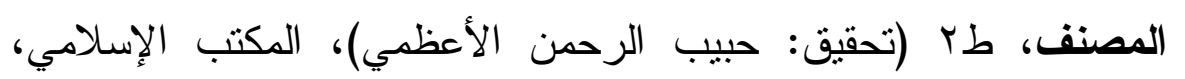

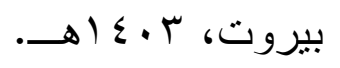




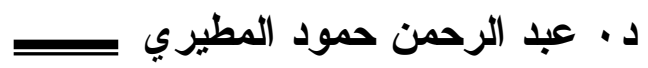

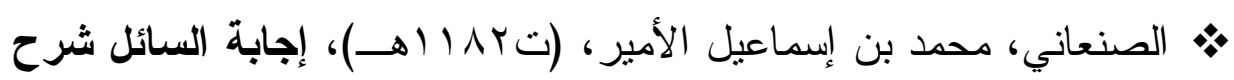
بغية الآمل، طا، (تحقيق: القاضي حسين بن أحمد السياغي والدكتور حسن محمد مقبولي الأهدل)، مؤسسة الرسالة، بيروت، 9191 (م.

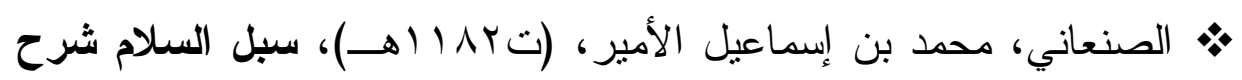

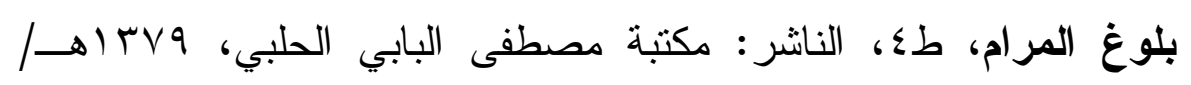
•) 97 .

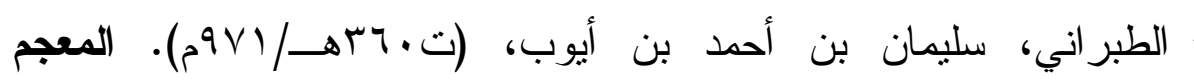
الأوسط، (تحقيق: طارق بن عوض الله بن محمد، و عبد المحسن بن إبر اهيم

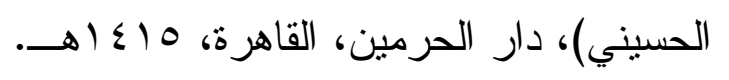

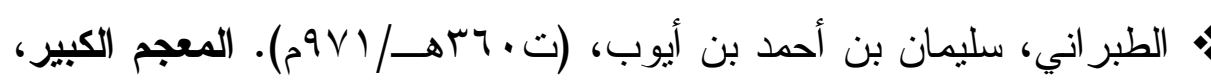
طب، (تحقيق: حمدي بن عبدالمجيذ السلفي)، مكتبة العلوم والحكم،

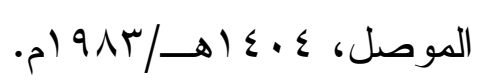

* الطحطاوي، أحمد بن محمد بن إسماعيل الحنفي، (ت اسب اهـ)، حاثية على مر اقي الفلاح شرح نور الإيضاح، الناشر: المطبعة الكبرى الأميرية

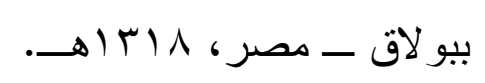

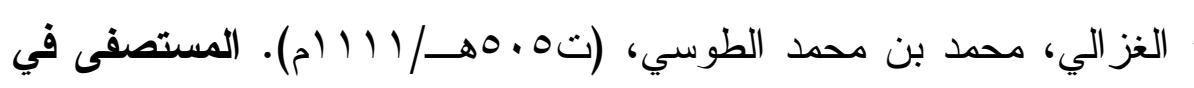
علم الأصول، طا. (تحقيق: محمد عبد السلام عبد الشافي)، دار الكتب

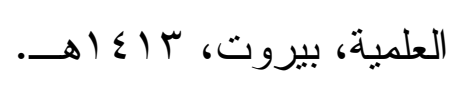

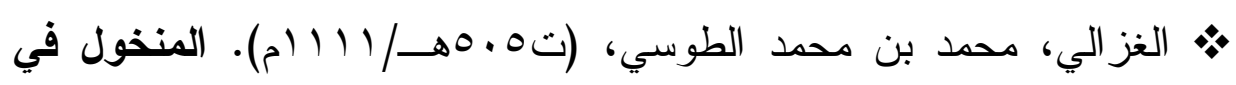
تعليقات الأصول، طب، (تحقيق: د. محمد حسن هيتو)، دار الفكر، دمشق، $\rightarrow\{\ldots$

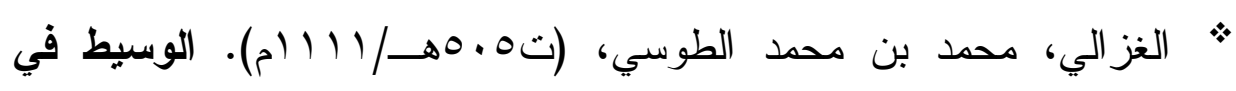
المذهب، طا، (تحقيق: أحمد محمود إير اهيم، محمد محمد تامر)، دار

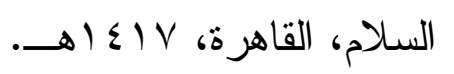




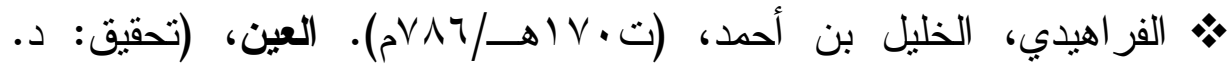

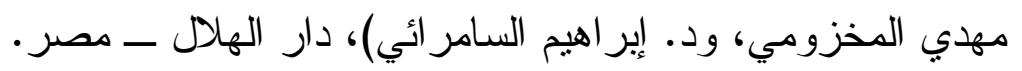

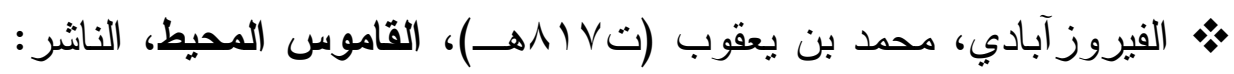
دار الكتب العلمية، بيروت.

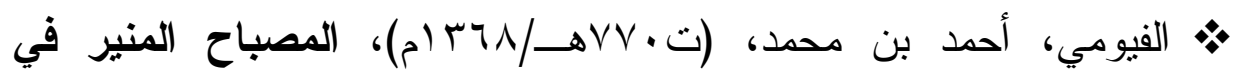
غريب الثرح الكبير للرافعي، المكتبة العلمية، بيروت.

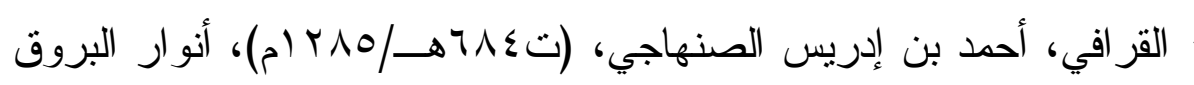

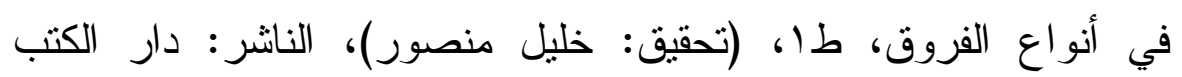

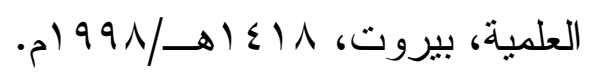

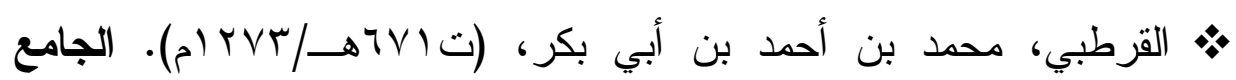

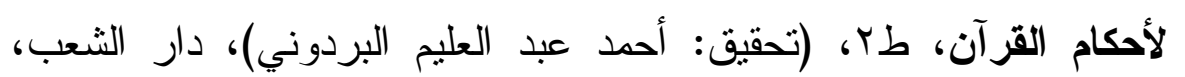
القاهرة، بVT اهــ.

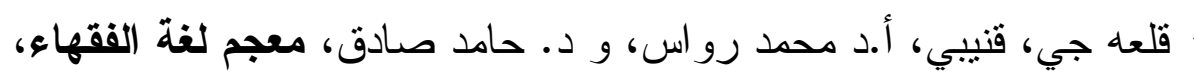

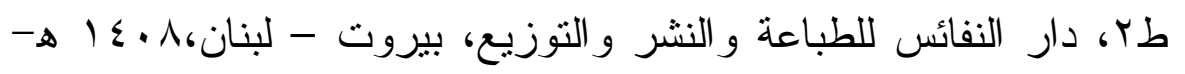
- 1911

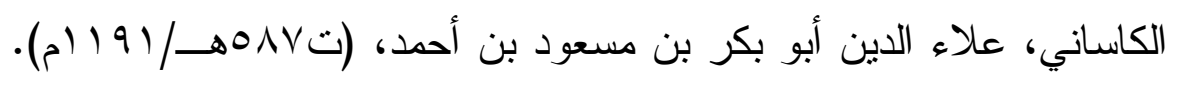

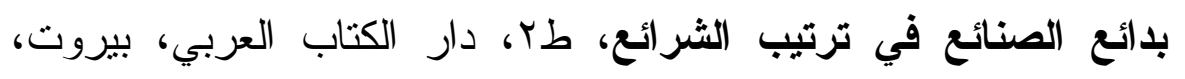
. 9194

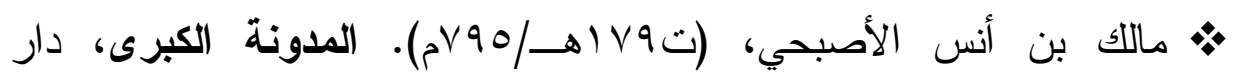
صادر ، بيروت. مان.

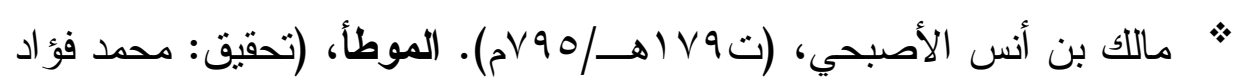

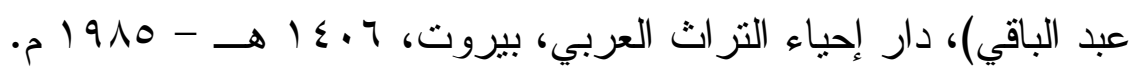




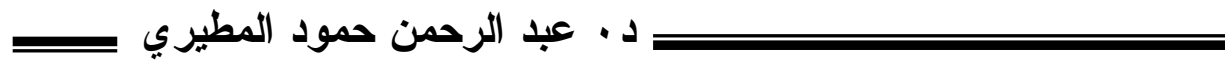

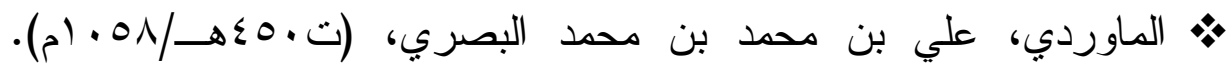
الإقتاع في الفقه الثافعي. الناشر : دار الفكر، بيروت.

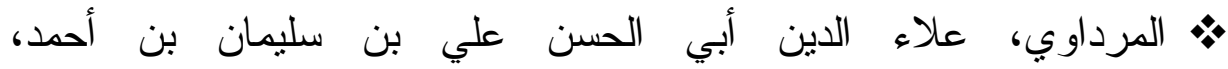

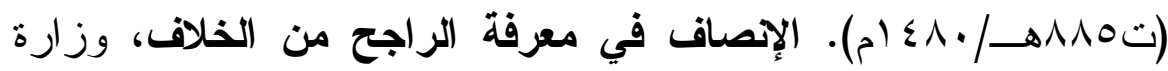

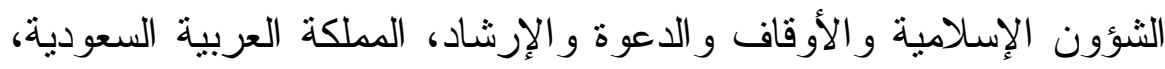
. $\rightarrow 1 \leqslant 19$

• مسلم بن الحجاج أبو الحسين القتشيري النيسابوري، (ت الهبهـ). صحيح

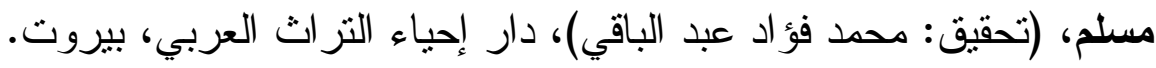

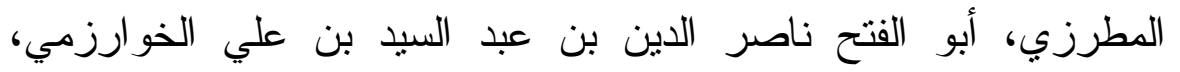

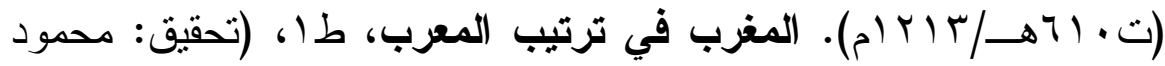

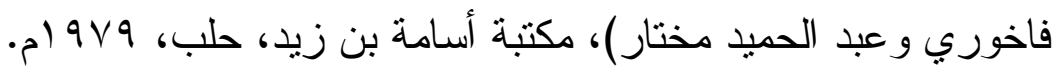

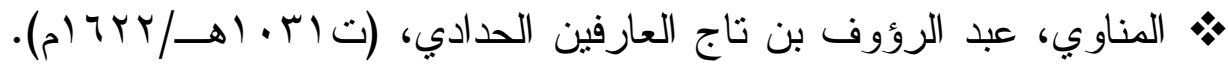

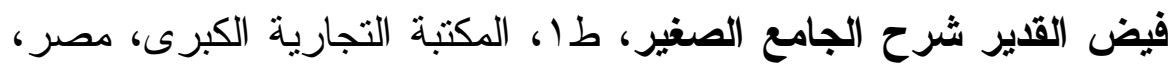

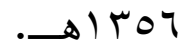

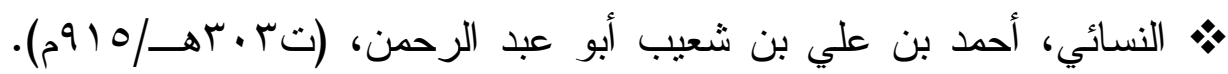

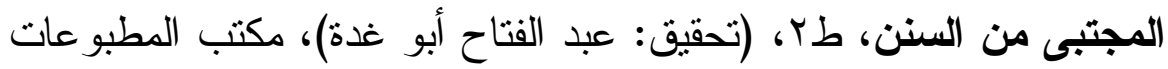

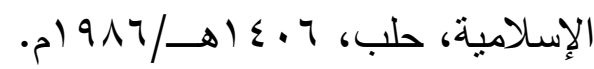

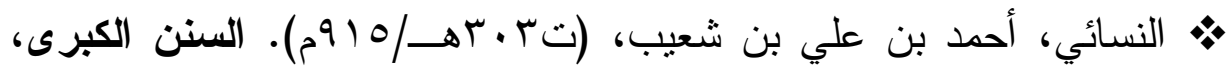

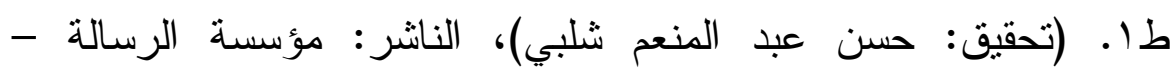

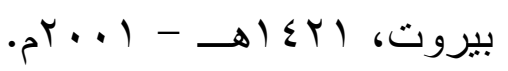

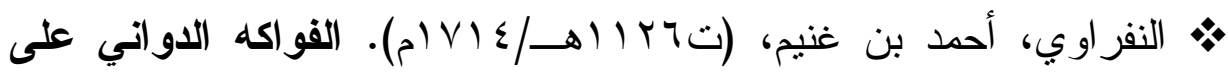

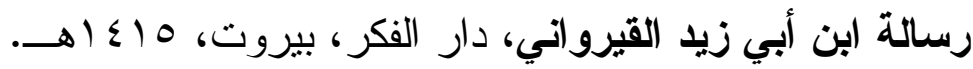




\section{=}

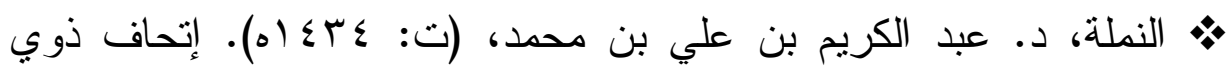

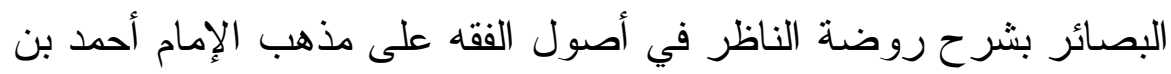

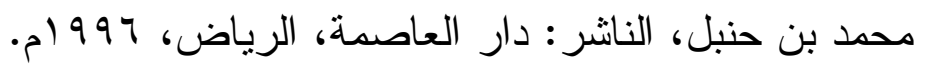

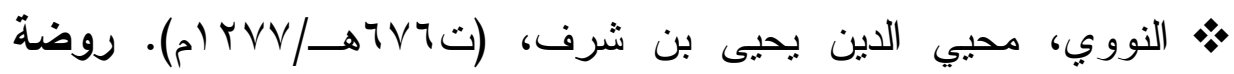

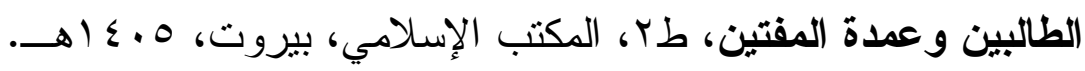

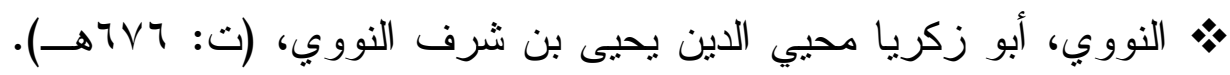
المجموع شرح المهذب، دار الفكر - بيروت.

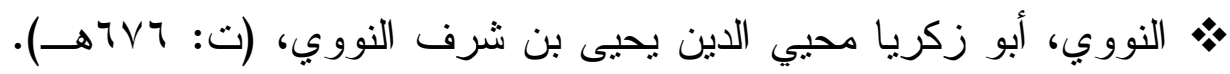

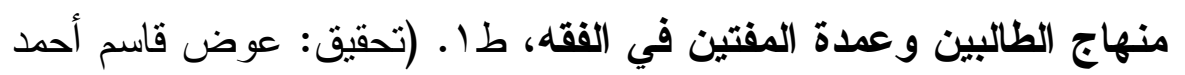

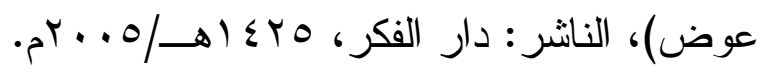

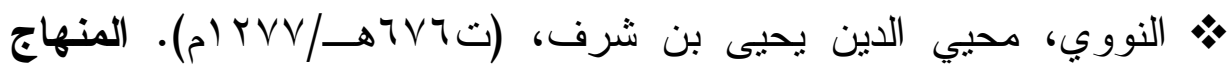

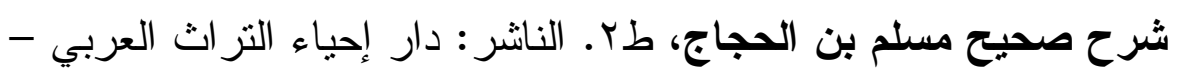
بيروت، ז9 أهـ.

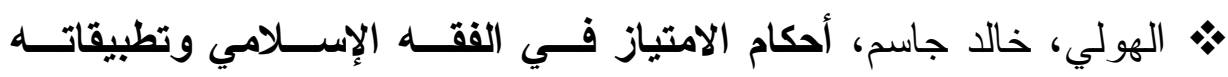

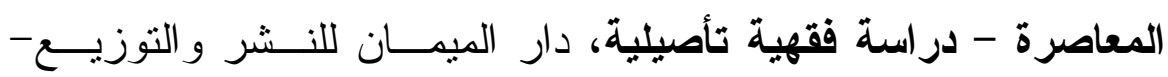

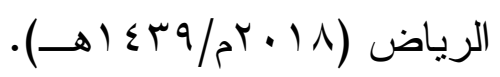

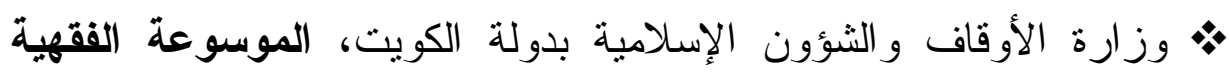

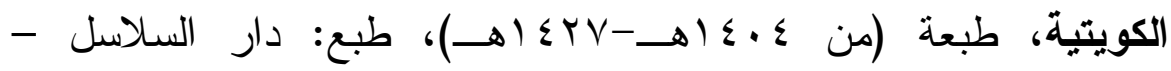
الكويت / مطابع دار الصفوة - مصر . من . مسنة 